\title{
REED
}

\section{BIRD GUIDE..}

\section{SMITHSONIAN \\ LIBRARISS}




\section{$\ln 38$ (1115NI

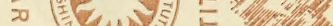 \\ (Tin)
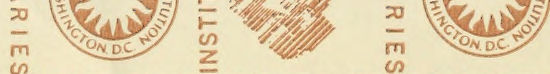

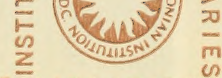 \\ os}

NOIINIIISNI
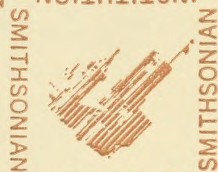

NVINOSHLIWS

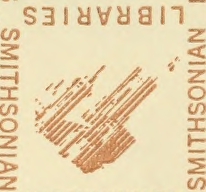

LIBRARIES

SMITHSONIAN
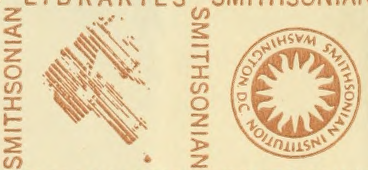

LIBRARIES SMITHSONIAN INSTITUTION

NOIINIIISNI

NVINOSHIIWS
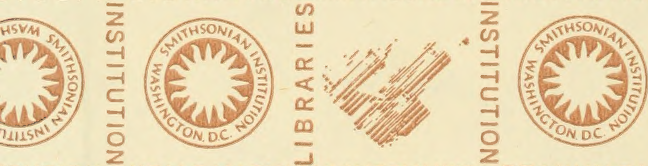

$\omega$
$\square$
$\alpha$
$\alpha$
$\infty$
$-\infty$

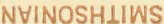

$\frac{z}{2}$
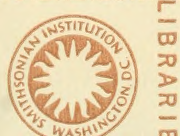

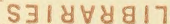

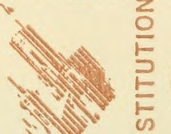

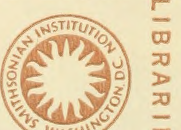

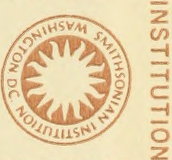

LIBRARIES

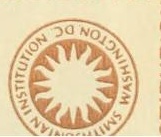

SMITHSONIAA

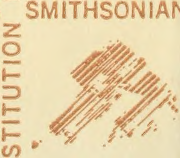




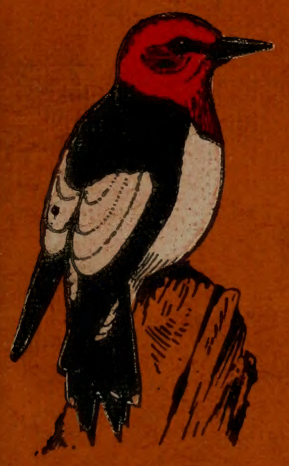

\section{REVISED EDITION}

\section{Bird Guide \\ Land Birds East of the Rockies}




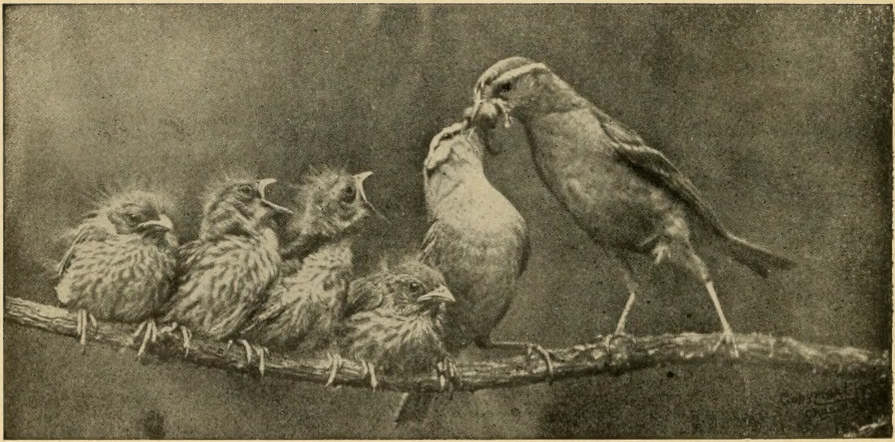

PREPARING BREAKFAST

(Two adult Chipping Sparrows breaking worm into pieces to feed young.) 



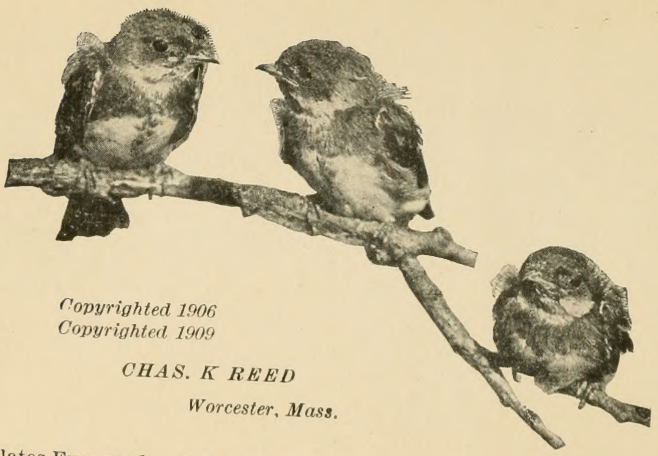

Plates Engraved and Printed by Quadri-Color Co.

Press of

A. M. Eddy. Albion, $\boldsymbol{N}$. 


\section{PREFACE.}

The native birds are one of our nation's most valuable assets. Destroy them, and in a comparatively few years the insects will have multiplied to such an extent that trees will be denuded of their foliage, plants will cease to thrive and crops cannot be raised. This is not fancy but plain facts. Look at the little Chickadee on the side of this page. She was photographed while entering a bird box, with about twenty-five plant lice to feed her seven young; about two hundred times a day, either she or her mate, made trips with similar loads to feed the growing youngsters.

It has been found, by observation and dissection, that a Cuckioo consumes daily from 50 to 400 catervillars or their equivalent, while a Chickadee will eat from 200 to 500 insects, or up to 4000 insect or worm eggs. 100 insects a day is a conservative estimate of the quantity consumed by each individual

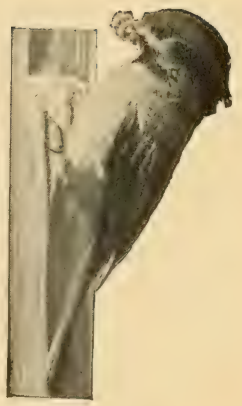


insectivorous bird. By carefully estimating the birds in several areas, I find that, in Massachusetts, there are not less than five insect-eating birds per acre. Thus this state with its 8000 square miles has a useful bird population of not less than $25,600,000$, which, for each days fare, requires the enormous total of $2,560,000,000$ insects. That such figures can be expressed in terms better understood, it has been computed that about 120,000 average insects fill a bushel measure. This means that the daily consumption, of chiefly obnoxious insects, in Massachusetts is 21,000 bushels. This estimate is good for about five months in the year, May to September, inclusive; during the remainder of the year, the insects, eggs and larvae destroyed by our Winter, late Fall and early Spring migrants will be equivalent to nearly half this quantity.

It is the duty, and should be the pleasure, of every citizen to do all in his or her power to protect these valuable creatures, and to encourage them to remain about our homes. The author believes that the best means of protection is the disseminating of knowledge concerning them, and the creating of an interest in their habits and modes of life. With that object in view, this little book is prepared. May it serve its purpose and help those already interested in the subject, and may it be the medium for starting many others on the road to knowledge of our wild, feathered friends.

Worcester, Mass., CHESTER A. REED.

October 1st, 1905. 


\section{INTRODUCTION.}

It is an undisputed fact that a great many of our birds are becoming more scarce each year, while a few are, even now, on the verge of extinction. The decrease in numbers of a few species may be attributed chiefly to the elements, such as a long continued period of cold weather or ice storns in the winter, and rainy weather during the nesting season: however, in one way or another, and often unwittingly, man is chiefly responsible for the diminution in numbers. If I were to name the forces that work against the increase of bird life, in order of their importance, I should give them as:-Man; the elements; accidents; cats; other animals; birds of prey; and snakes. I do not take into consideration the death of birds from natural causes, such as old age and disease, for these should be counterbalanced by the natural increase.

There are parts that each one of us can play in lessening the unnatural dangers that lurk along a bird's path in life. Individually, our efforts may amount to but little, perhaps the saving of the lives of two or three, or more, birds during the year, but collectively, our efforts will soon be felt in the bird-world.

How Can We Protect the Birds?-Nearly all states have fairly good game laws, which, if they could be enforced, would properly protect our birds from man, but they can not be; if our boys and girls are educated to realize the economic 
value of the birds, and are encouraged to study their habits, the desire to sinoot them or to rob them of their eggs will be very materially lessened. It is a common practice for some farmers to burn their land over in the Spring, usually about nesting time. Three years ago, and as far back of that as I can remember, a small ravine or valley was teeming with bird life; it was the most favored spot that 1 know of, for the variety and numbers of its bird tenants. Last year, towards the end of May, this place was deliberately burned over by the owner. Twenty-seven nests that I know of, some with young, others with eggs, and still others in the process of construction, were destroyed, besides hundreds of others that I had never seen. This year the same thing was done earlier in the season, and not a bird nested here, and, late in Summer only a few clumps of ferns have found courage to appear above the blackened ground. Farmers also cut off a great many patches of underbrush that might just as well have been left, thus, for lack of suitable places for their homes, driving away some of their most valuable assistants. The cutting off of woods and forests is an important factor in the decrease of bird life, as well as upon the climate of the country.

Our winter birds have their hardships when snow covers the weed tops, and a coating of ice covers the trees, so that the $y$ can neither get seeds nor grubs. During the nesting season, we often have long-continued rains which sometimes cause an enormous loss of life to insect-eating birds and their young. In 1903, after a few week's' steady rain and damp weather, not a Purple Martin could be found in Worcester rounty, nor, as far as I linow, in New England; they were 
wholly unable to get food for either themselves or their young, and the majority of them left this region. The Martin houses, when cleaned out, were found to contain young, eggs and some adults that had starved rather than desert their family. The Martins did not return in 1904 or 1905.

Birds are subject to a great many accidents, chiefly by flying into objects at night. Telephone and telegraph wires maim or kill thousands, while lighthouses and steeples often cause the ground to be strewn with bodies during migrations. Other accidents are caused by storms, fatigue while crossing large bodies of water, nests falling from trees because of an insecure support, and ground nests being trod upon by man, horses and cattle.

In the vicinity of cities, towns, villages or farms, one of the most fertile sources of danger to bird life is from cats. Even the most gentle household pet, if allowed its liberty out of doors, will get its full quota of birds during the year, while homeless cats, and many that are not, will average several hundred birds apiece during the season. After years of careful observation, Mr. E. H. Forbush, Mass. state ornithologist, has estimated that the average number of birds killed, per cat population, is about fifty. If a dog kills sheep or deer, he is shot and the owner has to pay damages; if a man is caught killing a bird, he pars a fine; but. cats are allowed to roam about without restriction, leaving death and destruction in their wake. All homeless cats should be summarily dealt with, and all pets should be housed, at least from May until August, when the young birds are able to fly. 
Of wild animals, Red Squirrels are far the most destructive to young birds and eggs; Chipmunks and Grays are also destructive but not nearly as active or impudent as the Reds. Skunks, Foxes and Weasels are smaller factors in the decrease of bird life.

Birds of prey have but little to do with the question of bird protection for, with a few exceptions, they rarely feed upon other birds, and nearly all of them are of considerable economic value themselves. Jays, Crows and Grackles, by devouring the eggs and young of our smaller birds, are a far greater menace than are the birds of prey, but even these have their work and should be left in the place that Nature intended for them; they should, however, be taught to keep away from the neighborhood of houses.

How Can We Attract Birds About Our Homes?-Many birds prefer to live in the vicinity of houses, and they soon learn where they are welcome. Keep your premises as free as possible from cats, dogs, and especially English Sparrows, and other birds will come. Robins, Orioles, Kingbirds, Waxwings and a few others will nest in orchard trees, while in dead limbs or bird boxes will be found Bluebirds, Wrens Swallows, Woodpeckers, Chickadees, etc.

A house for Purple Martins may contain many apartments; it should be erected in an open space, on a ten or twelve foot pole. Boxes for other birds should have but one compartment, and should be about six by six by eight inches, with a hole at least one and one-half inches in diameter in one side; these can be fas- 
tened in trees or on the sides or cornices of barns or sheds. It is needless to say that English Sl)arrows should not be allowed to use these boxes. By tying suet to limbs of trees in winter, and providing a small board upon which grain, crumbs, etc. may be sprinkled, large numbers of winter birds may be fed; of these, probably only the Chickadees will remain to nest, if they can find a suitable place.

How To Study Birds.-This refers, not to the scientific, but to the popular study of our birds, chiefly in the field. We can learn many very interesting things by watching our birds, especially during the nesting season, and the habits and peculiarities of many are still but imperfectly linown. One thing to be impressed upon the student at the start is the need of very careful observation before deciding upon the identity of a bird with which you are not perfectly familiar. A bird's colors appear to differ greatly when viewed in different lights, while in looking $u_{1}$, in the tree tops, it is often impossible to see any color at all without the aid of a good field glass. By the way, we would advise everyone to own a good pair of these, for, besides being almost indispensable for bird study, they are equally valuable for use at the sea shore, in the mountains or at the theatre. [We have examined more than a hundred malies of field glasses to select the one best adapted to bird study, and at a moderate price. We found one that was far superior to any other at the same price, and was equal to most of those costing three times as much. It gives a very clear image, magnifies about four diameters and has a very large field of view. It comes in a silk-lined, leather case, with cord for 
suspending from the shoulder, and is of a convenient size for carrying in the pocliet. We have made arrangements so that we can sell these for $\$ 5.00$, postpaid (money refunded if they are not satislactory after three days trial.) Order from Chas. K. Reed, Worcester, Mass.]

We should also advise everyone to lieep a note book, apart from the Bird Guide. At the end of the season you can write neatly with ink on the top of the pages of the Guide, the dates of the earliest arrivals and latest departures of the birds that you have recorded. If you see a bird that you do not recognize, malie the following notes, as completely as possible:-Length (approximately); any bright colors or patches; shape of bill, whether most lilie that of a finch, warbler, etc.; has it a medium or superciliary line, eye ring, wing bars, or white in the tail; what are its notes or song; does it keep on or near the ground, or high up; are its actions quick or slow; upon what does it appear to be feeding; is it alone or with other birds, and what linds; where was it seen, in dry woods, swamp, pasture, etc.; date that it was seen. With this data you can identify any bird, but usually you will need only to glance over the pictures in the Bird Guide to find the name of the bird you have seen.

I should advise anyone by all means to make a complete local list of all the birds that are found in their neighborhood, but of far greater value than the simple recording of the different species seen on each walk, will be the making a sliecial study of one or more birds, even though they be common ones. While, 
of course, notilig any peculiarities of any bird that you may see, select some particular one or ones and find out all you can about it. The following nost necessary points are cited to aid the student in making observations:-Date of arrival and whether in large flocks, pairs or singly; where found most abundantly; upon what do they feed at the different seasons; what are their songs and calls at different seasons; when and where do they malie their nests; of what are they made and by which bird or both: how long does it talie, and when is the first and last egg laid: how long does it talie them to hatch, and do both birds or only one incubate them; upon what are the young fed at different ages; how long do they remain in the nest, and do they return after once leaving: how long before they are able to feed themselves, and do they remain with their parents until they: migrate. These and other notes that will suggest themselves, will furnish interesting and valuable instruction during your leisure time. 


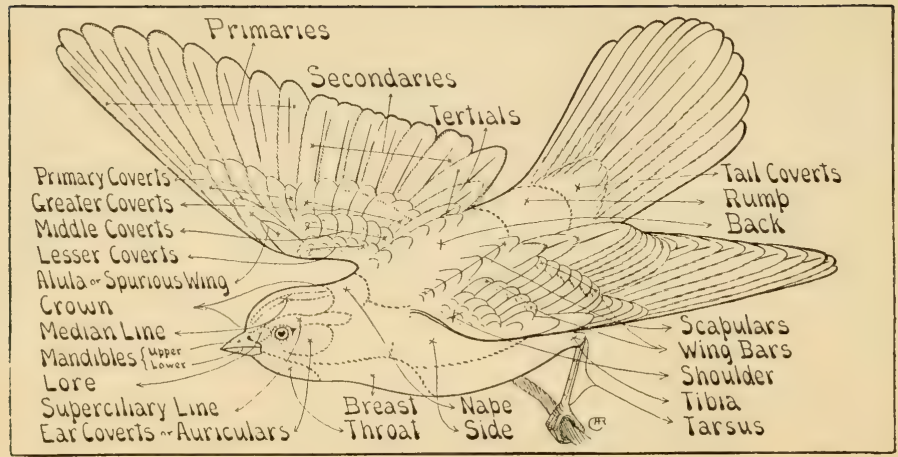

TOPOGRAPHY OF A BIRD 


\section{$B$ I $R$ G $U$ I $D E$}

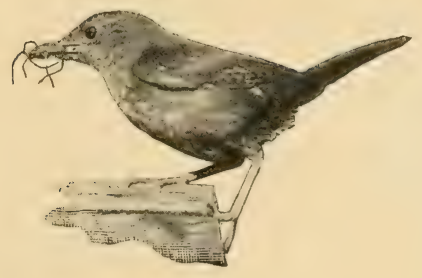

$$
\text { PART } 2
$$

Land Birds East of the Rockies 
The numbers and names used in this book are those adopted by the American Ornithologists' Union, and are known both in this country and abroad. The lengths given are averages; our small birds often vary considerably and may be found either slightly larger or smaller than those quoted.

On some of the pages a number of sub-species are mentioned. Sub-species often cause confusion, because they are usually very similar to the original; they can best be identified by the locality in which they are fround.

Of course the writing of birds' songs is an impossibility, but wherever I have thought it might prove of assistance, I have given a crude imitation of what it sounds like to me. The nests and eggs are described, as they often lead to the identity of a bird. We would suggest that you neatly, and with ink, make a cross against the name of each bird that you see in your locality, and also that you write at the top of the page, the date of the arrival and departure of each bird as you note it; these dates vary so much in different localities that we have not attempted to give them.

As many will not wish to soil their books, we would suggest that they have a leather covered copy for the library and a cloth one for pocket use. 


\section{CAROLINA PAROQUET.}

382. Conuropsis carolinensis, 121/2 inches.

Adults have the fore part of the head orange, while roung birds have the head entirely green, with only a trifle orange on the forehead.

With the exception of the Thick-billed Parrot which is very rarely found in southern Arizona, these are the only members of the Parrot family in the United States. They were once abundant throughout the southern states, but are now nearly extinct. They are found in heavily timbered regions, usually along the banks of streams, where they feed upon seeds and berries.

Note.-A sharp, rolling "kr-r-r-r-r." ( (hapman.)

Nest.- Supposed to be in lollow trees, where they lay from three to five white eggs $(1.31 \times 1.06 i)$.

Range.-Formerly the southern states, but now eonfined to the interior of Florida and, possibly, Indian 'Territory.

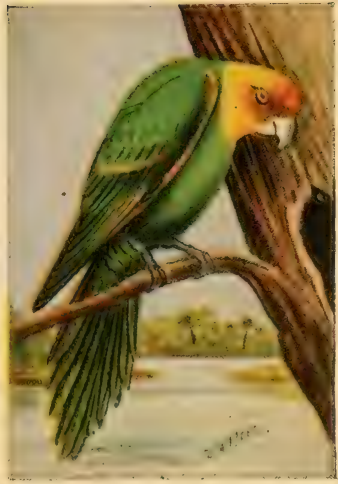




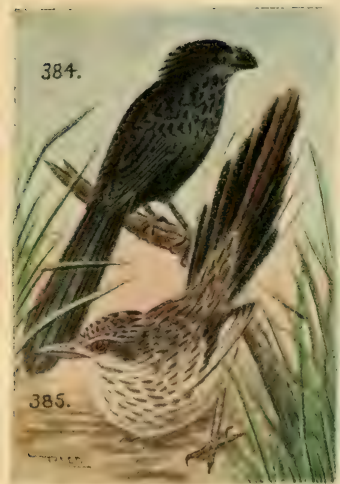

$1 \mathrm{~s}$

\section{GROOVE-BILLED ANI.}

384. Crotophaga sulcirostris. $14 \frac{1}{2}$ inches.

Anis are fairly abundant in southern Texas along the Rio Grande. Like all the members of the family of C'uckoos, their nesting habits are very irregular; ofttimes a number of them will unite and form one large nest in a bush, in which all deposit their eggs. The eggs are bluish-green, covered with a white chalky deposit $(1.25 \times .95)$.

\section{ROAD-RUNNER.}

385. (icococcyx culifornianus. 23 inches.

In the southwestern portions of our country, from Texas and Kansas west to the Pacific, these curious birds are commonly found. They are locally known as "Ground ('nckons," "Snake-killer's." "Chaparral ('ocks." They are very fond of lizards and small snakes, which form a large part of their fare. They are very tleet rumers, but fly only indifferently well. Their four to ten white eggs are laid on frail nests of twigs, in bushes. 


\section{MINGROVE CUCKOO.}

\section{6. Соссугиз minor. 13 inches.}

These buff-breasted C'uckoos are natives of C'uba and Central America, being found in southern Florida only during the summer. The habits of all the American ('uckoos are practically identical and their notes or songs ean only be distinguished from one another by long familiarity.

\section{YELLOW-BILLED CUCKOO.}

387. Coccyzus americanus. 121/1 inches.

This speeies is the most abundant in the southern part of its range. while the Black-hill is the most common in the North. Notice that the lower mandible is vellowish, that the wings are largely rufous, and that the outer tail feathers are black, with broad white tips, these point seadily distinguishing this species from the next. The eggs of this species are large and paler colored than the next $(1.20 \times .90)$. They breed from the Gulf to southern Canada and winter in Central America.

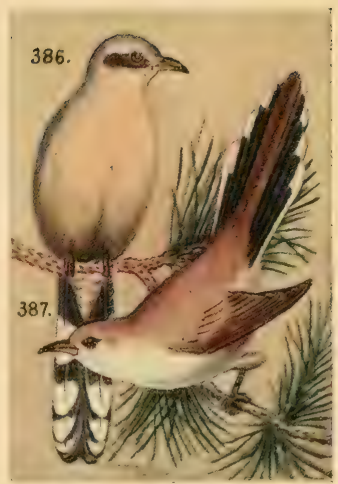




\section{BELTED KINGFISHER.}

\section{Ceryle alcyon. 13 inches.}

The male has the breast band and sides blue-gray, like the back, while the female has chestnut-colored sides and breast hand in addition to a gray band.

Kingfishers may be found about ponds, lakes, rivers, the sea-side or small creeks: anywhere that small tish may be obtained. Their food is entirely of fish that they cateh by diving for, from their perches on dead branches, or by hovering over the water until the fish are in proper positions and then plunging after them.

Note.-A very loud, harsh rattle, easily heard half a mile away on a clear, quiet day.

Nest. - At the end of a two or three-foot tumnel in a sand bank. The tumnel terminates in an enlarged chamber where the five to eight glossy white eggs ( $1.35 \mathrm{x}$ 1.05 ) are laid upon the sand.

Range.-Whole of North Ameriea north to the Arctic regions. Winters from southern United States southward.

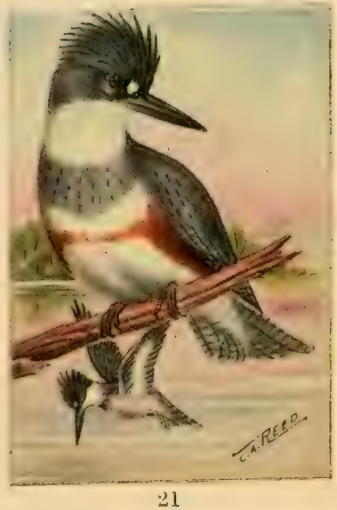




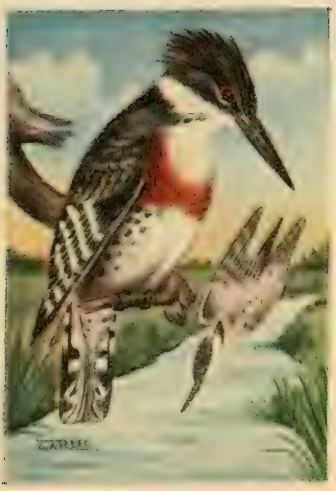

2.2

\section{TEXAS KINGFISHER.}

391. Ceryle americana septentrionalis. 8 inches. The adult male of this species has a rufous breast band, while the female has only a greenish one.

The Texan Green lingfisher is the smallest member of the family found within our borders. You will notice that all Kingfishers have the two outer toes on each foot joined together for about two-thirds of their length. This has been brought about through their habit of excavating in sand banks for nesting sites. It is quite probable that at some future distant perion the three forward toes mat be connected for their whole length, so as to give them a still more perfect shovel.

Note.-A rattling cry, more shrill than that of the Belted Kingfisher.

Nest. - I he four to six glossy white eggs are laid on the sand at the end of a horizontal burrow in a bank, the end being enlarged into a chamber sufficiently large to allow the parent birs to turn about.

Range.-Couthwestern lorder of the Cnited States, from southern Texas to Arizona. 


\section{IVORY-BILLED WOODPECKER.}

\section{Campephilu? principalis. 20 inches.}

Male with a scarlet erest, female with a black one.

These are the largest and most rare of the Woodpeckers found within our borders. Their decline in numbers is due, to a certain extent, to the killing of them because of their size and beauty, but chiefly on aceount of eutting off of a great deal of the heary timber where they nest. They are very powerful birds and often seale the bark ofl the greater portion of a tree in their search for insects and grubs, while they will bore into the heart of a living tree to make their liome.

Note.-A shrill two-srllabled shriek or whistle.

Nest.-In holes of large trees in impenetrible swamps. On the chips at the bottom of the eavity, they lay from three to six glossy, pure white eggs $(1.45 \times 1.00)$.

Range.-Formerly the South Atlantic States and west to Texas and Indian Territory, but now confined to a few isolated portions of Florida and, possibly, Indian Territory.

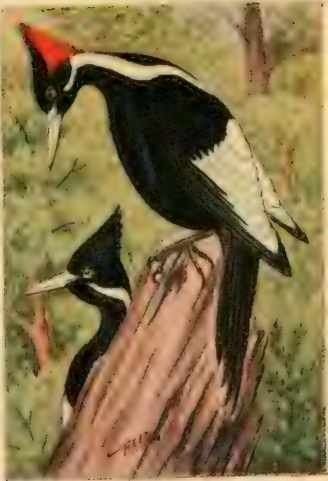

23 


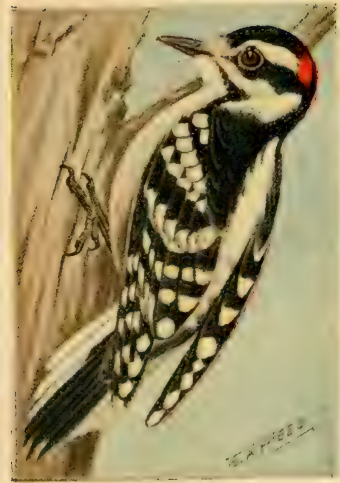

21
HAIRY WOODPECKER.

393. Dryobates villosus. 9 inches.

In summer these Woodpeckers are found in heavy woods, where they breed, but in winter they are often reen on trees about houses, even in the larger cities, hunting in all the crevices of the bark in the hope of locating the larva of some insect. They are uswally more shy than the Downy, from which they can readily be distinguished by their much larger size.

Note.-A sharp whistled "peenk."

Nest.-In holes in trees in deep woods; three to six glossy white eggs $(.95 \times .70)$.

Range.-Eastern L. S. from Camadil to North Carolina.

Sub-species.-393a. Northern Hairy Woodpecker (leucomelas), British America and Alaska: larger.3!)3b. Sonthern Hairy Woodpecker (andubonii), South Atlantic and Gulf States: smaller. The difference between these birds is small and chiefly in size, although the southern bird often has fewer white marks on the wing coverts. Other sub-species are found west of the liockies. 
SOUTHERN DOWNY WOODPECKER.

394. Dryobates mubscens. 6 inches.

The male has a red nuchal patch while the female has none. Downies are one of the commonest of our Woodpeckers and are usually tame, allowing a very close approach before flying. They remain in orehards and open woods throughout the summer, and in winter often come to the windows in places where they are fed, as many people are in the habit of doing now. Their food, as does that of nearly all the Woodpeckers, consists entirely of insects, grubs and larve.

Note.-A sharp "peenk" or a rapid series of the same note, usually not as lond as that of the Hairy Woodpecker.

Nest.-In holes in trees in orchards or woods, the four to six white eggs being laid on the bare wood; size $.75 \times .60$.

Range.- South Atlantic and Gulf States.

Sub-species.-Northern Downy Woodpecker (medianus), North America east of the Rockies and north of the Carolinas. This variety is slightly larger than the southern; others are found west of the Rockies.

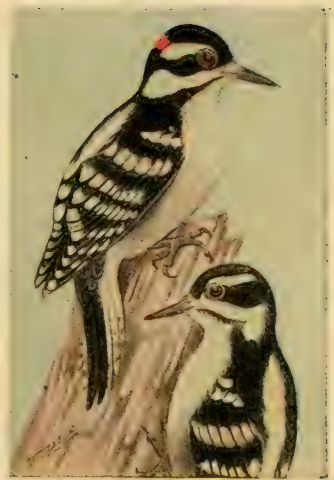

25 


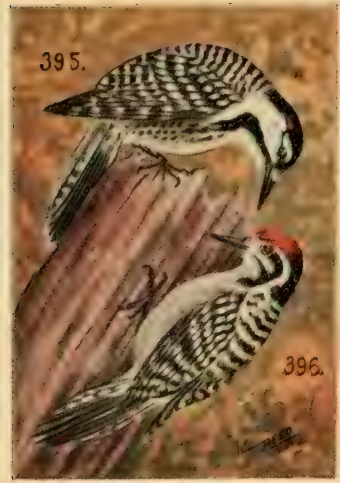

26

\section{RED-COCKADED WOODPECKER.}

\section{Dryobates borcalis. $81 / 4$ inches.}

Male with a small patch of scarlet on both sides of the head; female without. The actions and habits are very similar to those of the Downy. The birds can readily be identified at a distance by the cross-barring of white on the back. Their notes are harsher than those of the Downy and have more of the nasal quality, like those of the nuthatches.

Range.- Southeastern Cnited States, west to Texas and north to Virginia.

\section{TEXAN WOODPECKER.}

396. Diryobates scalaris bairdi. $71 / 1$ inches.

On account of its numerous cross bars, this species is often known as the Ladder-backed Woodpecker. They are quite similar to the Nuttall Woodpecker, that is found on the Pacific Coast, but differ in having the underparts hrownish-white instead of white, and the outer tail feathers heavily barred. They are found from Texas to southeastern California and north to Colorado. 


\section{ARCTIC THREE-TOED WOODPECKER.}

400. Picoides arcticus. 9.5 inches.

Back glossy black, without any white. Only three - toes, two in front and one behind. This is the most common of the two species found within the Lnited states. They breed from the northern edge of the Enion north to the limit of trees.

\section{AMERICAN THREE-TOED WOODPECKER.}

401. P'icoides americanus. S"/t inches.

Back barred with white; outer tail feathers barred with black: yellow crown pateh on male mixed with white. Excepit on some of the higher momtain ranges these birds appear in the Cnited states only during winter. They are very hardy and commence nesting before snow leaves.

Note.-A shrill, loud, nasal shriek, sometimes repeated.

Nest.-In holes of trees as is usual with Woodpeckers. The white eggs measure $.95 \times .70$.

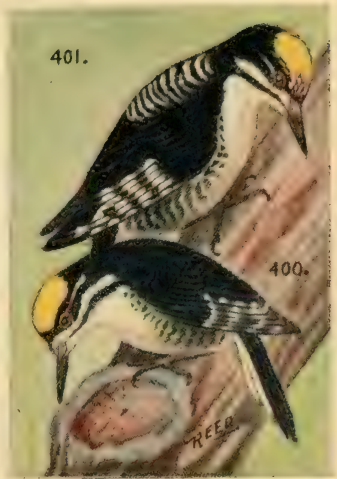

27 


\section{PILEATED WOODPECKER.}

\section{Pllocotomus pileatus. 17 inches.}

Male with a scarlet crown and crest, and a red moustache or mark extending back from the bill; female with searlet crest but a blackish forehead and no moustache.

Next to the Ivory-bills, these are the largest of our Woodpeckers. Like that species it is very destructive to trees in its search for food. While engaged in this pursuit, they often drill large holes several inches into sound wood to reach the object of their search. Like all the Woodpeckers. they delight in playing tattoos on dry, resonant limbs with their bills.

Note.-A whistled "cuk," "cuk," "cuk," slowly repeated many times, also a "wick-up" repeated several times.

Nest.-In large cavities in trees, in which they lay four to six white eggs $(1.30 \times 1.00)$.

Range.-Sunthern United States. The Northern Pileated Woodpeser (abieticola) is locally found in temperate N. A.

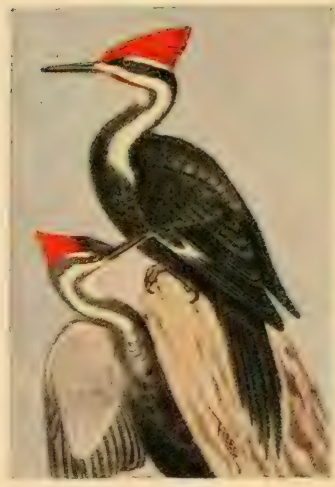

29 


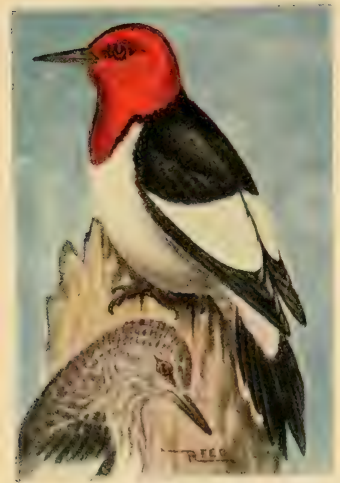

30

\section{RED-HEADED WOODPECKER.}

406. Ilelanerpes crythrocephalus. $93 / 1$ inches. Adults with entire head and breast red; young with a gray head and back, streaked with darker.

This very handsome species is common and very well known in the Middle and Central States. They are the ruflians of the family, very noisy and quarrelsome. One of their worst traits is the devouring of the eggs and young of other birds. To partially offset this, they also eat insects and grubs and a great deal of fruit.

Note.-A loul, whining "charr," "charr," besides numerous other calls and imitations.

Nest.-Holes in trees in woods, orchards or along roadsides and also in fence posts or telegraph poles. In Mlay and June they lay four to six glosisy white eggs $(1.00 \times .75)$.

Range.-- Inited States east of the Rockies, breeding fromi the Gulf to New York and Minnesota. Winters in southern United States. 


\section{RED-BELLIED WOODPECKER.}

409. Conturus carolinus. $91 \frac{1}{2}$ inches.

Nale with whole top of head and hack of neck red; female with forehead and hind head red but eromn gray. Both sexes have the center of the belly reddish, and have red eyes.

Like the Red-heads, these birds are noisy, but they have few of the bad qualities of the others. Besides the regular Woodpecker fare, they get a great many ants and beetles from the ground and fruit and acorns from the trees. They are said to also be fond of orange juice. In most of their range they are regarded as rather shy and retiring birds.

Note.-A sharp, resonant "cha," "cha," "cha," repeated.

Nest.-In holes bored usually in live trees and at any height from the ground. Their five or six eggs are glossy white $(1.00 \times .75)$.

Range.- - Inited States east of the Plains, breeding from Florida and Texas to southern Pennsylvania and Mimmesota. Winters along the Gulf coast; oceasionally strays to Massachusetts.

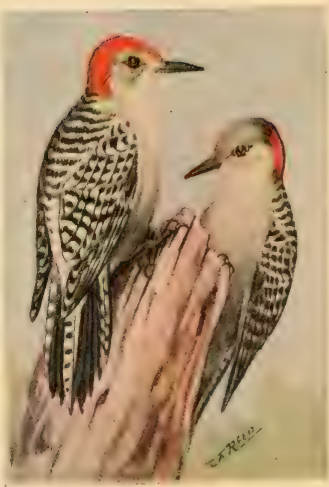

31 


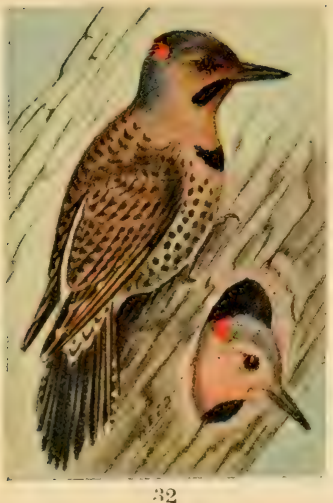

\section{FLICKER.}

412. Colaptes auratus. 13 inches.

Male with a black moustache mark; female without, although young females in the first plumage show some black.

These birds are very often known as "Golden-winged Woodpeckers," "Ifigh-holes" and about a hundred other names in different localities. Flickers are found commonly in woods, orchards or trees by the roadside; on pleasint dars their rapidly uttered, rolling whistle may be heard at all hours of the day.

Note.-A rapilly repeated whistle, "cul.", "cuk," "cul": an emphatic "quit-u," "quit-u," and several cthers of a similar nature.

Nest.-A cavity in a tree, at any distance from the ground. The white eggs ustally vary in number from five to ten. lut they have been known to lay as many as serenty-one, where an egg was taken from the nest each day.

Range.-South Atlantic States. The Northern Flicker (luteus) is found in North America east of the Rocky Mountains. 


\section{RED-SHAFTED FLICKER.}

413. Colaptes cafer collaris. 13 inches.

Crown brown and throat gray, these colors being just reversed from those of the eommon Flicker.

The male is distinguished by a red moustatehe mark. which the female lacks. The typical male Red-shafted Flicker lacks the red erescent on the back of the head, but it is often present on individuals, as there are numerous hybrids between this speeies and the preceding. Flickers are more terrestrial in their habits than are any ethers of the family: their food consists largely of ants which they get from the ground.

Note.-Same as those of the last; both species often utter a purring whistle when they are startled from the ground.

Nest.-The nesting hahits are identical with those of the last and the exgs camnot be distinguished.

Range.-From the eastern slope of the Rocky Mountains to the Pacific.

3

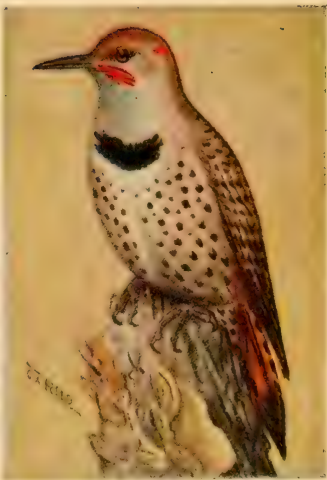

33 


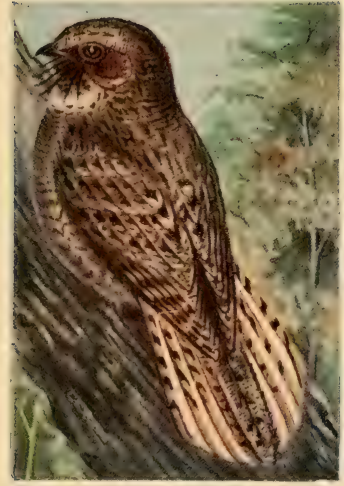

34
CHUCK-WILL'S-WIDOW.

416. Antrostomus carolinensis. 12 inches.

Male with the end half of the outer tail feathers white, and the edge of the outer vanes rusty: female with no white ends to the feathers. Birds of this family have small bills, but extremely large mouths adapted to eatching night-flying moths and other insects. They remain sleeping during the day, either perched lengthwise on a limb or concealed beside a stump or rock on the ground, their colors harmonizing with the surroundings in either case. They fly, of their own aceord, only at dusk or in the early morning. This species, which is much the largest of our Goatsuckers, is known to, at times, devour small birds, as such have been found in their stomachs.

Note.-A loudly whistled and repeated "chuck-will'swidow."

Nest.-None, the two eggs being laid on the ground or dead leaves in underbrush. Eggs white, blotehed with gray and lavender $(1.40 \times 1.00)$.

Range.-South Atlantic and Gulf States, breeding north to Virginia and Missouri, west to Texas. 


\section{WHIP-POOR-WILL.}

417. Antrostomus ruciferus. $9 \%$ inches.

Male with broad white tips to outer tail feathers: female with narrow bufly tips. These birds are often confounded with the Nighthawk, but are very easily distinguished by the long bristles from base of bill, the black chin, the chestnut and black barred wing feathers and the rounded tail. Whip-poor-wills are more nowturnal than Nighthawks and on moonlight niglits continue the whistled repetition of their name throughout the night. They eapture and devour a great many of the large-bodied moths that are found in the woods, but are never seen flying over cities like Nighthawks.

Note.-An emphatically whistled repetition of "whippoor-will," "whip-poor-will."

Nest.-In June they lay two grayish or ereamy white eggs $(1.15 \times .85)$, mottled with pale brown, gray and lilac. These are deposited on the ground in woods.

Range.-East of the Plains, breeding from the Gulf to Manitoloa and New Brumswick. Winters south of the United States.

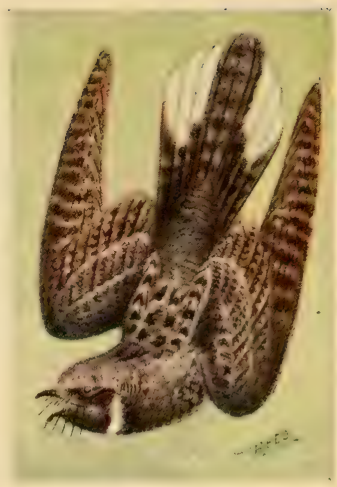

:3is 


\section{NIGHTHAWK.}

420. Chordeiles virqinianus. 10 inches.

Male with white throat and white band across tail; female with rusty throat and no white on tail. Notice that the Nighthawk has a forked tail and white band across the wings, thus being readily distinguished at a distance from the Whip-poor-will.

Note.--A loud nasal "peent."

Nest.--None, the two mottled gray and white eggs being laid on bare rocks in pastures, on the ground or under brush, or on gravel roofs in eities: size $1.20 \times$.t 5 .

Range.- - Tnited States east of the Plains, breedins from Florida to Labrador: winters south of [nited States. Three sub-speeies oceur:-420a. Western Nighthawk (henryi), west of the Plains: 420b. Florida Nighthawk (ehapmani); $420 \mathrm{c}$. Sennett Nighthawk (sennetti), a pale race found on the Plains north to Saskatchewan.

\section{TEXAN NIGHTHAWK}

421. Chordeiles acutipemis terensis.

This species is found in southern Texas and New Mexico. It differs from the last in having the primaries spotted with rusty, like those of the whip-poor-will.

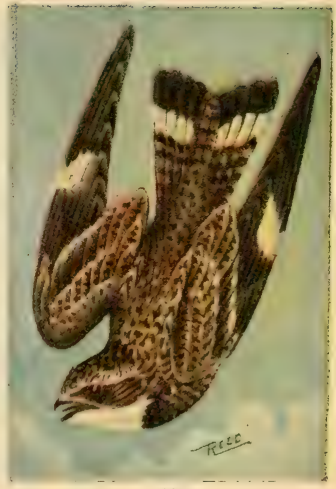

37 


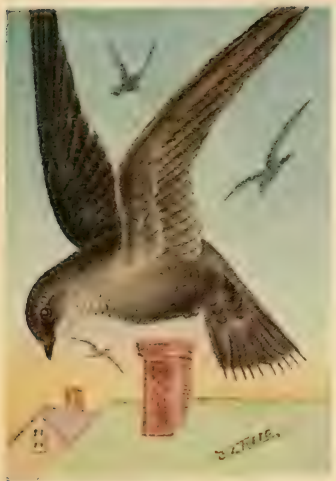

38

\section{CHIMINEY SWIET.}

423. rherture prlugire. $5^{1} 2$ incless.

Enused chimmeys of old dwellings make favorite roosting and nesting places for these smoke-colored hirds. They originally dwelt in hollow trees until the advent of man furnished more convenient places. although we would searcely comsider the suot-lined brick surfare at gond at a clean hollow tree. cyines on the end of ateli tail feather enable them to hang to their upright walls. and to slowly hitch their way to the outer world. Throughout the day mumber of them are sonuring the air for their fare of insects. but as night alproatches. they return to the chimmey.

Note.- I continuons and not ummm-ical twittering uttered while on the wing and also within the depths of the chimney.

Nest.-Made of small stickis or twigs glued to the siles of a chimmer and each other by the hirels saliva. The three to five white excs are lone and narrow $(.75 \times .50)$.

Range.-X. A. east of the Plains. hreeding from Florida to Labrador; winters south of $\mathrm{L}$. S. 


\section{WHITE-THROATED SWIFT.}

425. Aeronautes melunoleneus. $61 / 2$ inches.

This beautiful swift is one of the most graceful of winged creatures. Its flight is extremely rapid and its evolutions remarkable. They nest in communities. thousands of them often congregating about the tops of inaccessible clitis, in the crevices of which they make their homes. No bird has a more appropriate greneric name than this species-" aeronautes," meaning sailor of the air: he is a sailor of the air and a complete master of the art.

Note.-Loud, shrill twittering, utered chiefly while on the wing.

Nest.-- Placed at the end of burrows in earthy cliffs or as far back as possible between erevices in rockis: nsually in inacessible places and as high as possible from the gromnd. It is a siucer-shaped structme made of regetable materials cemented together with saliva, and lined with feathers. The four white exgs measure $.87 \times .52$.

Range.-From the eastern foothills of the Rockies to the Pacific; north to Montana and northern ('alifornia.

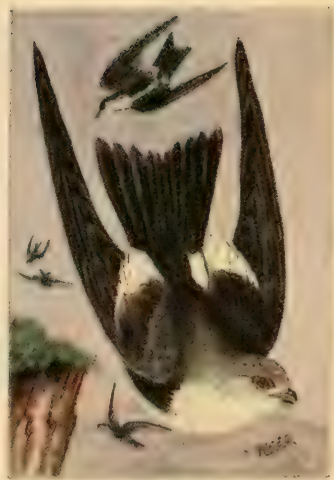




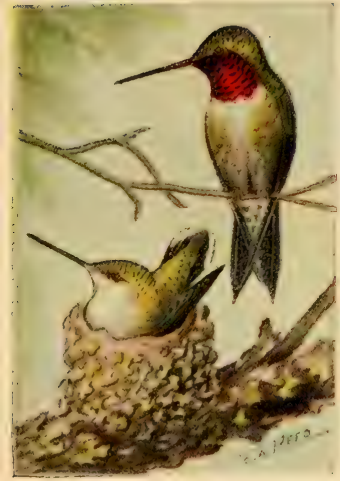

40

\section{RUBY-THROATED HUMIMINGBIRD.}

428. Archilorhus colubris. $: 31 / 2$ inches.

This little gem is the only one of the family found within the territory included in this book. Owners of flower gardens have the best of opportunities to study these winged jewels, on their many trips to and fro for honey, or the insects that are also attracted thereby. With whirring wings, they remain suspended before a blossom, then-buzz-and they are examining the next, with bill lost within the sweet depths. Their temper is all out of proportion to their size, for they will dash at an intruder about their moss-covered home as though they would pierce him like a bullet. Their angry twitters and squeaks are amusing and surprising, as are their excitable actions.

Nest.-A most beautiful creation of plant fibres and cobwebs adorned with lichens and resembling a little tuft of moss upon the bough on which it is placed. In June two tiny white egus are laid $(.50 \times .35)$.

Range.- N. A. east of the Rockies, breeding from the Gulf north to Labrador and Hudson Bay; winters south of U. S 


\section{SCISSOR-TAILED FLYCATCHER.}

443. II uscivora forficata. $141 / 2$ inches.

This pretty creature is the most graceful in appearance of the Flycatcher family, if not of the whole order of perching birds. In the southwest it is irequently known as the "Texan Bird of Paradise." Its habits are very much like those of the Kingbird; as it gracefully swings through the air in pursuit of insects, it frequently opens and shuts its scissor-like tail. They are usually found in open country or on the borders of woodland. They rarely alight on the ground, for their long tails make them walk very awkwardly, but when they are a-wing they are the embodiment of grace.

Note.-A shrill "tzip," "tzip," similar to notes of ringbirds.

Nest.-Quite large: built of all kinds of trash, such as twigs, grasses, paper, rags, string, ete.; placed in any kind of a tree or bush and at any height. The four or five creamy white eggs are spotted with brown $(.90 \times .67)$.

Range.-Breeds from Texas north to Kansas; winters south of U. S.

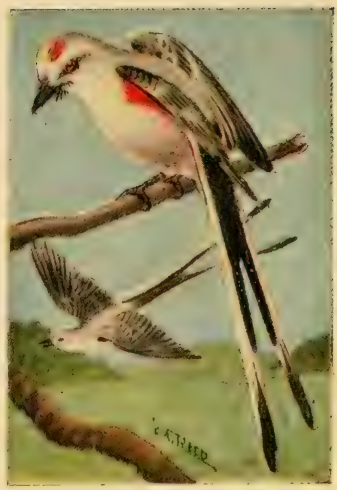

41 


\section{KINGBIRD.}

444. Tyrannus tyramms. $81 / 2$ inches. Adults with a concealed orange crown patch; young with none. From the time of their arrival in May until they leave us in August, Kinghirds are much in evidence in farmyards and orchards. They are one of the most noisy birds, always quarreling about something. and usually coming ofl rictorious in whatever they may undertake. Crow's are objects of hatred to them, and they always drive them from the neighborhood, vigorously dashing upon and picking them from above and often following them for a great distance. They have their favorite perches from which they wateh for insects, usually a dead branch, a fence post, or a tall stalk in the field.

Note.-A series of shrill, harsh sounds like "thsee." "thisee."

Nest.-()f sticks, rootlets, grass, string, etc.. placed in orchard trees or open woods at any height. Four or five creamy white exgs, specked and spotted with red. dish brown $(.95 \times .70)$.

Range.-Breeds from the Gulf to southern Canada. 


\section{GRAY KINGBIRD.}

445. Tyrannus dominiscensis, 9 inches.

Differs from the common Kingbird in being larger and gray above; has black ear coverts, and no white tip to tail.

Like the last species, these are very noisy and pugnacions, and rule their domains with the hand of a tyrant. After they have mated they quarrel very little among themselves, and often several may use the same lookout twig from which to dash after passing flies or moths.

Note-A rapidly repeated, shrill shriek: "pe-che-ri," "pe-che-ri."

Nest.-Rather more shabbily built but of the same materials at those used by our common Kinghird. Placed in all kinds of trees. but more often in mangroves. Where they are commonly found. Three to five pinkisli-white eggs, profusely blotehed with brown $(1.00 \times .72)$.

Range.-West Indies and Florida, Georgia and South Carolina. Winters in the llest Indies and ('entral Americo.

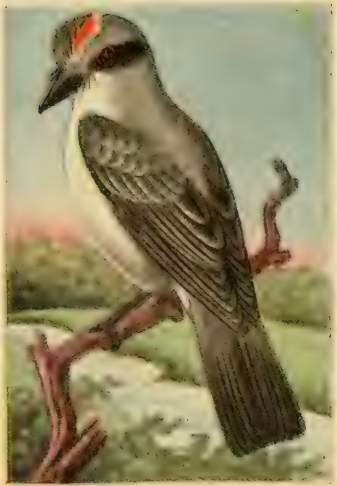

43 


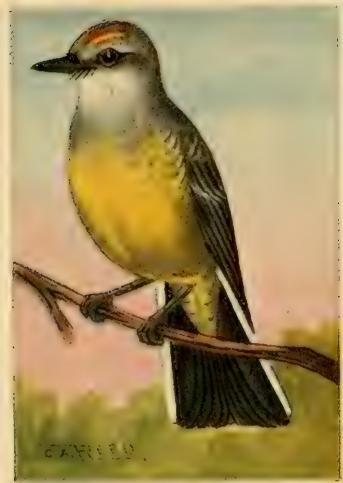

44

\section{ARKANSAS KINGBIRD.}

\section{Tyrannus verticalis. 9 inches.}

These tyrant flycatchers are abundant west of the Mis sissippi, where they are often, and perhaps more aptly, known as the Western Kingbirds. If possible, they are even more noisy and pugnacious than the eastern species. They have a great variety of notes, all rather unpleasant to the ear. Their food, like that of the other Kingbirds, consists of moths, butterflies, ants, grasshoppers, cricketc., ete., most of which they catch on the wing.

Note.-A shrill, metallic squeak: a low twittering and a harsh, discordant seream, all impossible to print.

Nest.-Quite large and clumsily made of paper, ragr, twigs, rootlets and grasses, placed in all sorts of locations, frequently in eave troughs or above windows. The eggrs are creamy white, spotted with brown (.95 $\mathrm{x}$ $.65)$.

Range.-Western Lnited States, breeding from Texas to Manitoba and west to the Pacific; winters south of U. S. 


\section{DERBY FLYCATCHER。}

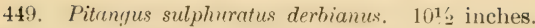

This imposing llycatcher is the largest of the family that is found in forth Americal. As usual with members of the fimily it is of a quarrelsome disposition, but hardly so much so as either the common or Arkinsits kinglirds. Their large, heary bodies render them considerably less active than the smaller members of the family. On aceount of the size of the head and bill, they are often known as Bull-headed Flycatchers.

Notes.-Very varied. but similar in character to those of the eastern Kingbird.

Nest.- It is said to build its nest at low elevations ir. trees or in thorny bushes-a large structure of twigs and rubbish with an entrance on the side. The three to five eggs have a cream-colored gromil and are prominently specked abeut the large end with brown $(1.15 \mathrm{x}$ $.82)$.

Kange.-A Mexican species that is fairly common in the Lower Rio Grande Valley in Texas.

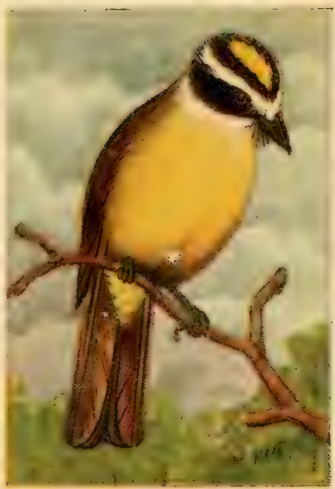

4.5 


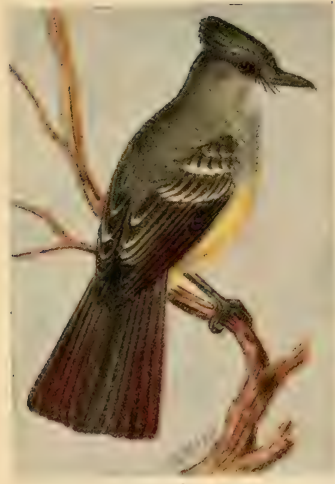

46

\section{CRESTED FLYCATCHER.}

452. Myiurchus crinitus. 9 inches.

These large flyeatchers are very noisy in the mating season, but their notes are rather more musical than those of the Kingbirds. They appear to be of a quarrelsome disposition, for rarely will more than one pair be found in a single piece of woods. They also frequently chase smaller birds, but never attack larger ones, is do the Kingbirds. They have a queer habit of placing a piece of snakeskin in the hole in which their nest is located, for what purpose, unless to scare alway intruders, is not known, but it seems to be a universal practice.

Notes.-1 clear whistle. "wit-whit," "wit-whit," repeated several times. This is the most rommon call; they have many other's less musical.

Nest.-Of straw, etc., in holes of dead limbs. Eggs four to six in number; bufiy white, streaked ard blotehed with brown.

Range.-Eastern $\mathrm{N}$. A. from the Plains to the Atlantic, breeding north to soutlern Cimada. 


\section{PHOEBE.}

456. Sayornis phabe. $i$ inches.

A Phebe is always associated, in my mind, with old bridges and bubbling brooks. Nearly every bridge which is at all adapted for the purpose has its Phocbe home beneath it. to which the sime pair of birds will return year after year, sometimes building a new nest, suanetimes repairing the old. They seem to be of a nervous temperament, for, as they sit upon their usual lookout perch, their tails are enitinually twitehing as though in anticipation of the insects thiat are sure to pass sooner or later.

Note.-A jerky, emphatic "pho-be,' with the accent on the second syllable, and still further accented by a vigorous flirt of the tail.

Nest.-Of mud, grasses and moss, plastered to the sides of beams or logs under bridges, culverts or harns. In May or June four or five white eggs are laid (.7.5 $\mathrm{x}$ $.55)$.

Range.--N. A. east of the Rockies, north to southern Canada: winters in southern $\mathrm{C}$. S. and southward.

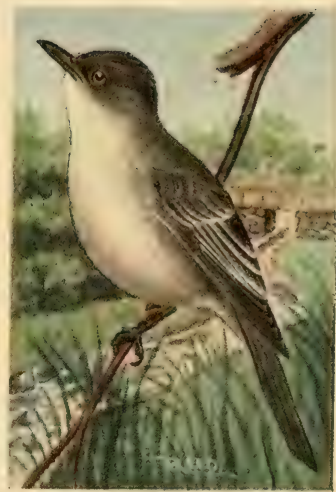

47 


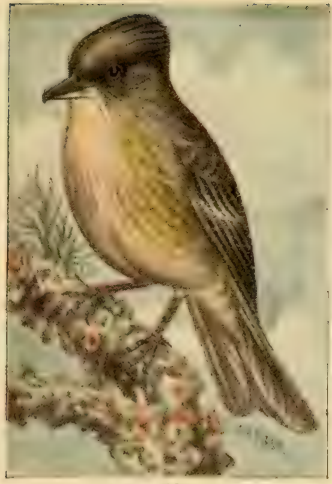

48

\section{OLIVE-SIDED FLYCATCHER.}

459. Tuttalornis borealis. $71 / 2$ inches.

These birds can scarcely be called common anywhere, but single pairs of them may be found, in their breeding range, in suitable pieces of woodland. I have always found them in dead pine swamps, where the trees were covered with hanging moss, making it very diflicult to locate their small nests. Their peculiar, loud, cleat whistle can be heard for a long distance and serves as a guide-board to their location.

Note.-A loud, clear whistle, "whip-wheeu," the first syllable short and sharp, the last long and drawn out into a plaintive ending.

Nest.-A small structure for the size of the bird, made of twigs and mosses firmly anchored to horizon tal liml:s or forks. Three to five egges are laid: a rice creany gromel, spotted about the large end with brow and lavender $(.85 \times .65)$.

Range.-N. A., breeding from the latitude of Mass chusetts, and farther south in mountainous regio north to Labrador and Alaska. 
WOOD PEWEE.

461. Myiochanes virens. $60^{1} \div$ inches.

In life, the Pewee can best be distinguished from the larger Phobe, with which it is often confounded, by its sidl, plimtive "pe-ah-wee," "pee-wee," which is strokingly ditferent trom the brusque all of the Pinetee. Pewees are also found more in high, dry woods where they build their little moss-covered homes on horizmtal boughs at quite a height from the ground. Like the other fiyeatehers they always perch on dead twigs, where their view is as little obstructed as possible.

Note.-A clear, plaintive whistle, "pe-ah-whee," "peewee."

Nest.-One of the most exquisite of bird creations, composed of plant fibres quilted together and ornimented with rock lichens; situated at varying herghts m horizontal limbs, jreferably oak or chestnut. and sometimes in apple trees in orchards. Liggs cheamy ihite, specked with brown $(.80 \times 5.5)$.

Range.-L. - . from the Plains to the Atlantic and orth to Manituba and New Brunswick; winters in jentral America.

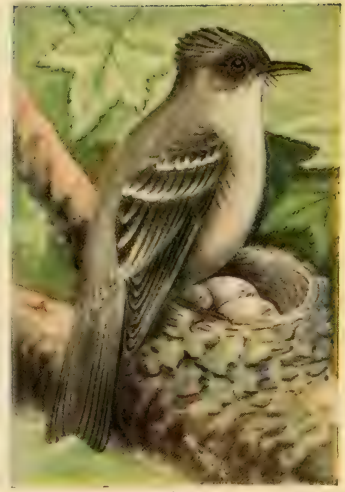




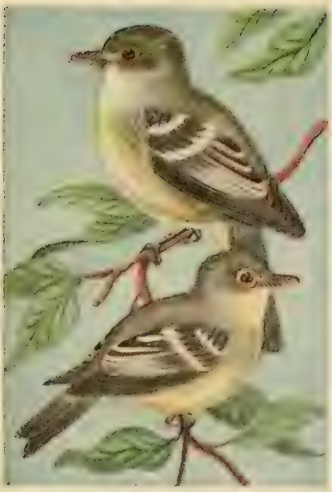

50
YELLOW-BELLIED FLYCATCHER.

46:3. Empidonax flutitentris. $5^{1} \frac{1}{2}$ inches.

These strange little Flycatchers are found in swamps such as those usually frequented by Olive-sided Flyeatchers and Parula Warblers. They are one of the few of the family to nest on the ground or very close to it. Their homes are made in the moss-covered mounds or stumps found in these swamps.

Range.-N. 1. (aist of the Plains north to Labrator, breeding from northern C. S. northward.

\section{GREEN-CRESTED OR ACADIAN FLYCATCHEIR,}

4ti.). Eimpidonux rirescens. $5^{1 / 2}$ inche's.

This bird is very similar to the last. but the lower mandible is light, and the throat and belly white. Their farorite resorts are shady woods not far from water. Here they nest in the outer branches of bushes or trees at levights of from four to twenty feet from the ground. The nests are shallow and composed of twigs and moss. Egrgs creamy with brown spots.

Range.-C. S. east of Plains, breading from the (inlf to Nev: England and Manitoba: winters in the Tropies. 


\section{ALDER FLYCATCHER.}

466a. Empidonas trailli aluorum. 6 inches.

This species is very similar to, but larger, than the well-known Least Flycateher or Chebec. They are found in swampy pistures or around the edges of ponds or lakes, where they nest in low bushes.

Range.-[. S. ealst of the Mississippi; breeding from New York to New Brunswick.

\section{LEAST FLYCATCHER.}

467. Eimpidonax minimus. $51 / 2$ inches.

Smaller than the last and with the tail slightly forked. Common everywhere in orelards, swamps or along roadsides. They are very often known by the name of "Chebee," because their notes resemble" that word. Their nests are placed in upright forks of any kind of trees or bushes; they are male of plant fibres and grasses closely felted together. The egges range from three to five in number and are creamy white, without markings; size .65 ×.50.

Range.-N. A. east of the Rockies, breeding from middle U. S. north to New Brunswick and Manitoba.

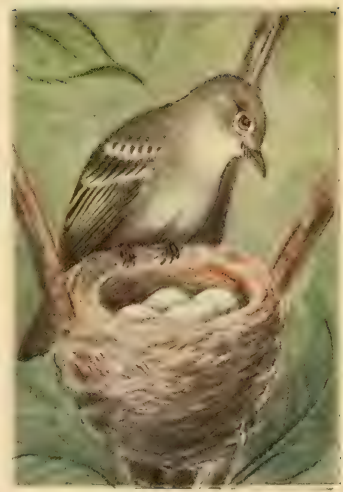

.51 


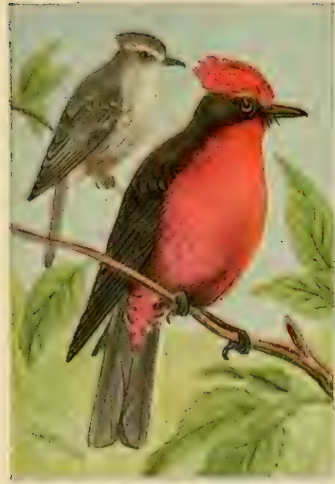

$0^{2}$

\section{VERIMILION FLYCATCHER.}

471. Pyrocephalus rubinus mexcanes. 6 inches.

Female with only a slight tinge of pink, where the male is brilliant vermilion.

This is the most gorgeously plumaged species of the American filycatchers. It has all the active traits of the family and, to those who are only aceustomed to the demure gray plumage of most eastern species, the first sight of this one as he dashes after an insect is a sight never to be forgotten.

Notes.-Durmg the mating season the male often gives a twittering song while poised in the air, accompanying it by lowd snapping of the mandibles.

Nest. - Saddled on limbs of trees at low elevations from the ground: composed of small twigs and vegetable fibres closely felted together and often adorned on the outside with lirhens similar to the nests of the Wood P'ewee. The four eggs are of a creamy-buff color with bold spots of brown and lilac, in a wreath around the large end $(.73 \times .54)$.

Range.-Mexican border of the United States, from Texas to Arizona. 


\section{HORNED LARK.}

474. Otocoris alpestris. $7: \% / 1$ inches.

This variety, which is larger than its sub-species, is only found in the U. S. in winter, but several of the sub-species are residents in our limits. During the mating season they have a sweet somg that is uttered on the wing, like that of the Bobolink.

Notes.-Alarm note and call a whistled "tseet," "treet"; song a low, sweet and continued warble.

Nest.-A hollow in the ground lined with grass; placed in ficlels and usually partially concealed by an overhanging sod or stome. The three to tive exos have a grayish ground color and are profusely specked and blotehed with gray and brownish (.85 x .60).

Range.-Breeds in Labrador and about Hudson Bay; south in winter to South (arolina and Illinois.

Sub-species.-47+b. Prairie Horned Lark (prationla). A paler form usually with the line over the eve white found in the Mississippi Valley tite. Desert Horned Lark (lenesiema). Paler and less distinctly streaked above than the Prairie; found west of the Jississippi and north to Alberta.

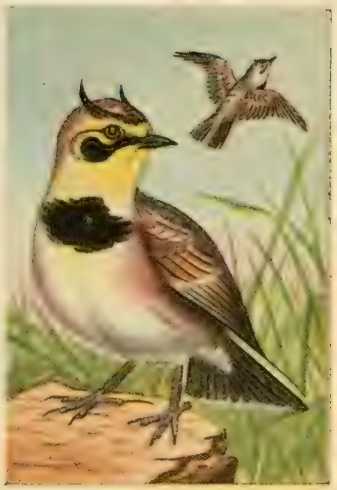

53 


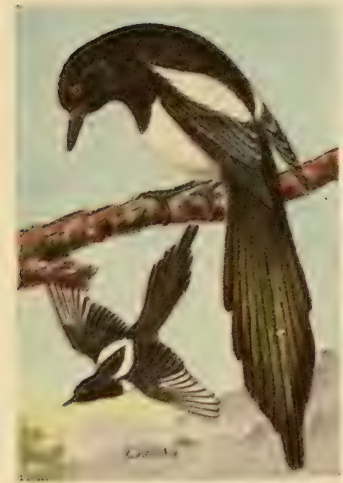

54

\section{AIIERICAN MAGPIE.}

475. P’ica pica lutelsonia. 20 inches.

This handsome member of the Crow family is sure to attract the attention of all who may see him. He is very pert in all his actions, both in trees and on the oround, and is alwars ready for mischief. In a high wind their long tail often makes traveling a laborions operation for them, and at such times they usually remain quite quiet. They are very impudent and always on the lookont for something to steal: they are also very noisy and forerer solding and chattering among themselves.

Notes._A loul, harsh "calck." "cack," and an endless variety of whistles and imitations.

Nest.-A large globular healy of sticks placer in bushes or trees from four to fifty feet from the aroment. The entrance to the nest is on one side and the interion is made of grats and mud. The four to six eggos are white, thickly specked with yellewish brown $(1.25 \times 90)$.

Range.-iVestern North America, east to the I'lains and north to Alaska: resident. 


\section{BLUE JAY.}

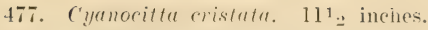

These are one of the best known and most beantiful linds that we hare, but. unfortunately, they have a rery batd reputation. They often rob other birds of their exges and youmg as well as food and nesting material, They are rery active lirds and are always engatged in wathe ing food, usually acorns or other nuts, and hiding them away for future use.

Notes. - I two-srllabled whistle or a harsh, discordant scream. Bexides these two common notes ther make an endless variety of sommels mimicking ot her hirds.

Nest.-Of twigs and sticks in huslees or low trees, preferably young pines. The four egos are pale greenish blue specked with brown $(1.10 \times .80)$.

Range. - N. A. east of the Rockies fiom the fiulf to Labrador. restent in the $\mathcal{C}$. S. The Florida Blue Jay (florincola) is smaller and hats less white on wongs anit tail.

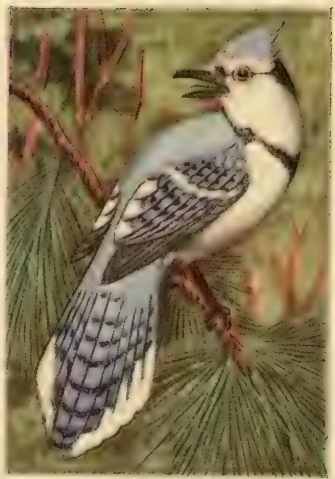

$5 \overline{5}$ 


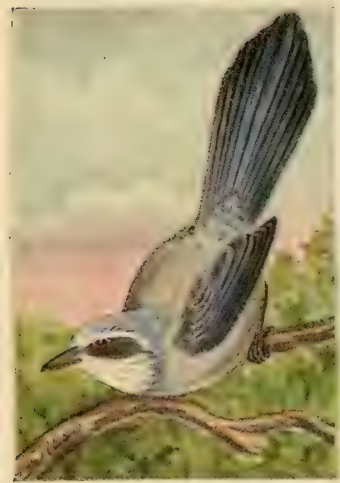

56

\section{FLORIDA JAY.}

479. Aphelocoma cyance. $11 \frac{1}{2}$ inches.

This Jay is locally distributed chiefly in the southern parts of lilorida, being found principally in scrub oaks. Like the Blue Jay, their food eonsists of animal matter and some seeds, berries and acorns. Their habits are very similar to those of the northern bird and their calls resemble those of our bird, too. 'They are rather slow in flight and pass a great deal of their time upon the ground.

Notes.-A "jay," "jay," similar to that of the Blue Jay, and a great variety of other calls.

Nest.-In the latter part of March and in April they build their flat nests of twigs, usually in bushes or serub oaks, and lay three or four greenish-blue eggs, with brown spots; size $1.05 \times .80$.

Range.-Middle and southern portions of Florida, chiefly along the coasts. 


\section{GREEN JAY.}

483. Tanthoura luxuosa glaucescens. 12 inches.

These Jays are very beautiful, and we are sorry to have (o) admit that, like all the other members of the family, they are merciless in their treatment af smaller birds. During the summer their diet consists of raw egres with young birds "on the side," or vice versa; later they live iuon nuts, berries, insects; in fact, ancthing that is edible.

Notes.-Practically unlimited, being imitations of those of most of the birrls in the ricinity.

Nest. - Not easily found, as it is usually encealed in dense thickets. The nests are like those of other Jays, loosely made of twigs and lined with black rootlets. The four eggs that are laid in May have a gravish ground color and are thickly spotted with several shade's of brown and lilac. They measure $1.05 \times .80$.

Range.-Fairly common in the Lower Rio Grande Valley in southern 'Texas.

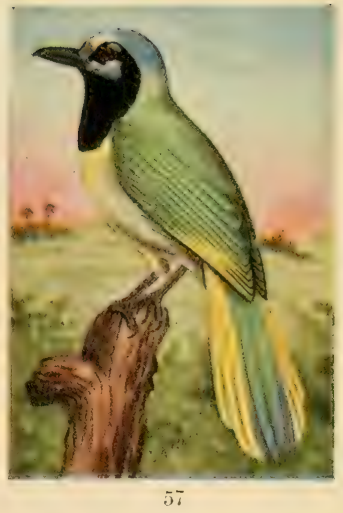




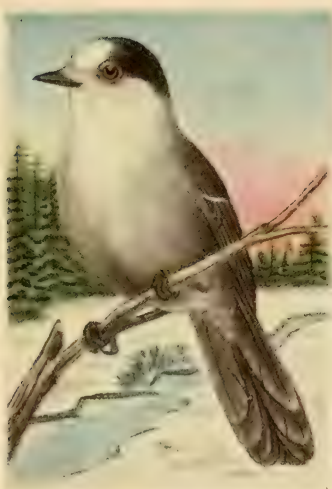

๖े

\section{CANADA JAY.}

4S.i. Perisoreus canatensix. 111.2 inches.

These birds are well known to hunters, trappers and campers in the northern woods. They are great in iends, especially of the lumbermen, as some of the pranks that they play serve to enliven an otherwise tedious day. They seem to be devoid of fear and enter camp and carry ofl everything. exlible or not, that they cam get hold of They are ealled by guides and lumbermen by various names, such as Whiskey Jack, Moose Bird, ete.

Notes.-A harsh "cal-cal-cal," and various other" sounds. Nest.- Csually in coniferous trees at low elevations: made of twigs, moss and feathers. The three or four egow are gray, specked and spotted with darker (1.15 $\mathrm{x}$ $.80)$. They nest early, usually before the snow begins to leave the gromel and often when the mereury is below zero.

Range.-Eastern North Americal from northern United States morthward. 4ste. Labrador Jay (nigri(appillus). Which is found in Labrador, lats the black on the hind head deeper and extending forward around the cre. 


\section{NORTHERN RAVEN.}

486a. Cortus corac principulis. 2.5 inches.

The halbits of all the ravens and crows are jelentical and are too well known to need mention. They are all very destructive to young lirds and exges. The Raven can be known by its large size, its very large bill and laneeslate feather's on the throat. They are fouml in the mountains from Georgia and on the (nast from Maine northwards.

\section{WHITE-NECKED RAVEN.}

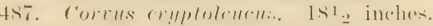

This species hats the bases of the feathers on the back of the neck white. Found in southwestern Lnited states.

\section{AMERICAN CROW.}

\section{4\$8. Cormes brechumliynchos. 19 inches.}

The common ('row of North Americar. replateded in Florida by the very sinilar Florida (row (pascums).

\section{FISH CROW.}

490. Corvus ossifragus. 16 inches.

This small specices is found on the Atlantic eorat north to Massachusetts.

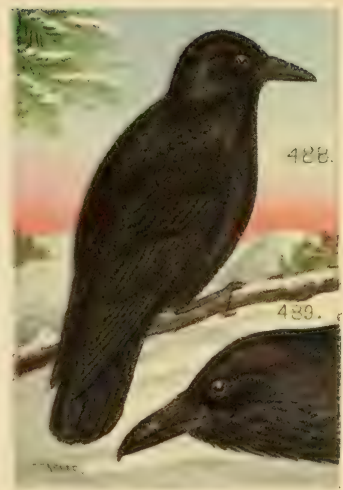




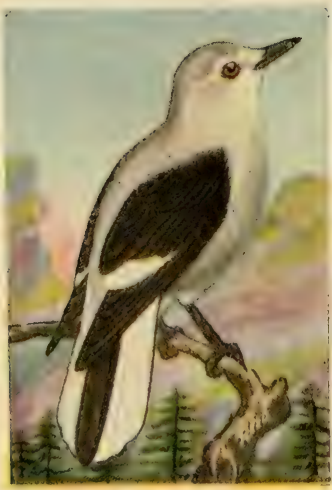

(i)

\section{CLARKE NUTCRACKER.}

491. Vucifiayu columbiana. 121/2 inches.

Clarke C'rows are found abundantly in all coniferous forests on the higher mountains in their range. They are very peculiar birds, having some of the traits of Nocdpeckers, but more of those of the Jays.

Ihey are very active, very noisy and very inquisitive, sharing with the Rocky Mountain Jay the names of "Camp Robber," "Moose Bird," etc. They are great travellers and may, one season, be absent where they were abundant the preceding one.

Notes.- Tarious ealls and imitations like those of all others of the Jay family.

Nest.-Oi sticks, at high elevations on horizontal boughs of coniferous trees. The four eggs have a pale greenish-gray ground, thickly sprinkled with darker $(1.25 \times .92)$.

Range.-IInuntains of western North America, casu ally east to Kansas. 


\section{STARLING.}

493. Sturnus vulgaris. $8 \frac{1}{2}$ inches.

Plumage metallic green and purple, heavily spottel above and below with butly or white.

These European birds were introluced into New York a number of vears ago, and are now common there and spreading to other localities in connecticut and about New York ('ity. They live about the streets and in the parks, building their nests in crevices of buildings and especially in the framework of the elevated railruads of the eity, and less often in trees. They lay from four to six pale-blue, unspotted eggs (1.15 x .85). How they will affect other bird life, in case they erentually become common throughout the country, is a matter of conjecture, but from what I have seen of them they are quarrelsome and are masters of the English sparrow, and may continue their domineering tactics to the extent of driving more of our song birds from the cities.

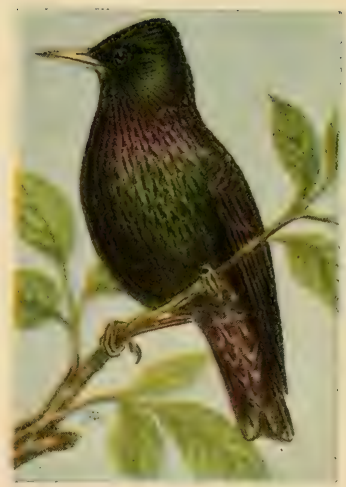

61 


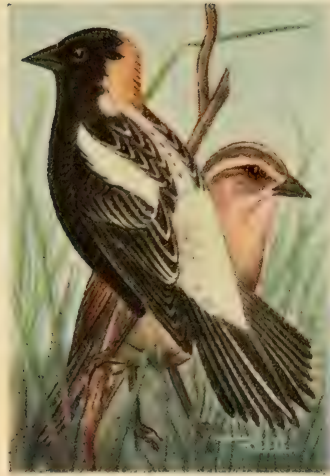

62

\section{BOBOLINK.}

494. Dolichomyx oryzurorus. $71 / 1$ inches.

Bobolinks are to be found in rich grass meadows, from whence their sweet, wild music is often borne to us by the breeze. While his mate is feeding in the grass or attending to their domestic aflairs, Mr. Bobolink is usually to be found perched on the tip of a tree. weed stalk, or eren on a tall blade of grass, if no other spot of vantage is available, singing while he stands guard to see that no enemies approach. He is a good watchman and it is a diflicult matter to flush his mate from the nest, for she leares at his first warning.

Song. - A wild, sweet, rippling repetition of his name with many additional trills and notes. Alarm note a harsh "chah" like that of the Blackbird.

Nest.-Of grasses in a hollow on the ground, in meadows. They lay four to six eggss with a white ground color, heavily spotted, elouded and blotehed with brown $(.85 \times .62)$.

Range.-N. A, east of the Rockies, breeding from New Jersey and Kamsas north to Manitoba and New Brunswick; winters in South America. 


\section{COWBIRD.}

495. Molothrus ater. $7 \% \frac{1}{4}$ inches.

Male glosiy greensh black, with a hrown head; female and young, dull gray.

Groups of these buds are often seen walking sedately about among the cons in the pasture, hence their name. They are the only birds that we have that neither make a nest of their own nor atre for then yomug. The female slyly deposits here egg in the nest of a smaller hird when the owner is absent, leaving further are of it to its new owner. Warblers, sparrows and Vireos seem to be most imposed upon in this manner.

Notes.-A low "chack," and by the male a liquid. wiry squeak aceompanied by a spreading of the wings and tail.

Range.-[*. S., chiefly east of the Rockies, lneeding from the Gulf to Manitolat and New Brunswick: winters in southern L. S. A sub-species, the Dwarf Cowbrod (obscurus), is found in soutliwestern Lnited states; it is slightly smaller.

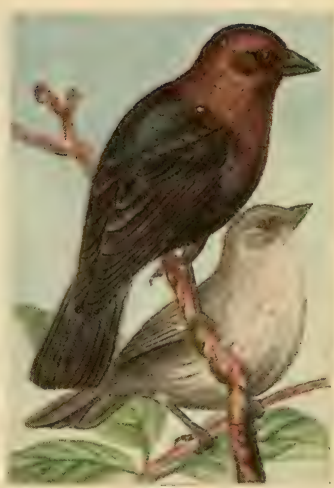

33 


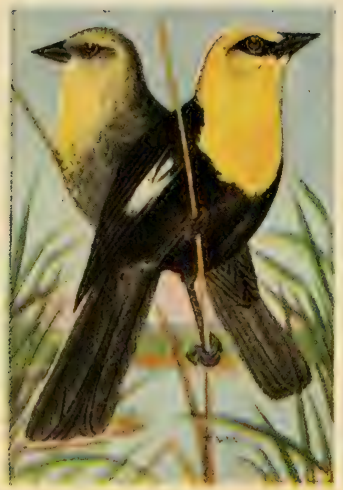

61

\section{YELLOW-HEADED BLACKBIRD.}

497. Tanthocephalus xanthocephalus. 10 inches. Male black, with head and breast bright yellow; female more brownish and with head paler and mixed with brown.

These handsome birds are common locally on the prairies, frequenting sloughs and extensive mirshes and borders of lakes. They are very sociable birds and breed in large colonies, sometimes composed of thousands of birds.

Notes.-A harsh "chack." and what is intended for a song, consisting of numerous, queer sounding squeaks, they being produced during seemingly painful contortions of the singer.

Nest.-Of rushes woven around upright canes over water, in ponds and slonghs. The nest is placed at from four inches to two feet from the water and is quite deep inside. The four to six egges are grayish, profusely specked with pale brown $(1.00 \times .70)$.

Range.-[. S., chiefly west of the Missis-ippi, north to Britisn Columbia and Iludson Bay; winters on southwestern porder of the $\mathrm{U} \mathrm{S}$. 


\section{RED-WINGED BLACKBIRD.}

498. Ageluius phomicens. $91 \frac{1}{2}$ inches.

IIale black, with scarlet and buff shoulders; female brownish black above and streaked below. Nearly all our ponds or wet meadows have their pair or colony of Blackbirds.

Note.-A harsh cack; a pleasing liquid song, "conkerr-ee," given with much bowing and spreading of the wings and tail.

Nest.-Usually at low elevations in bushes, in swamps or around the edges of ponds, or frequently on the ground or on hummocks in wet pastures. The nest is mate of woven grasses and rushes, and is usually partially suspended from the rim when placed in bushes. The three to five eggs are bluish white, scrawled, chiefly around the large end, with blackish $(1 .(00 \times .70)$.

Range.-East of the Rockies, breeding north to Manitol)a and New Brunswick; winters in southern $\mathrm{C}$. S.

Sub-species. - 498b. Bahaman Redwing (bryanti). +98c. Florida Redwing (floridanus).

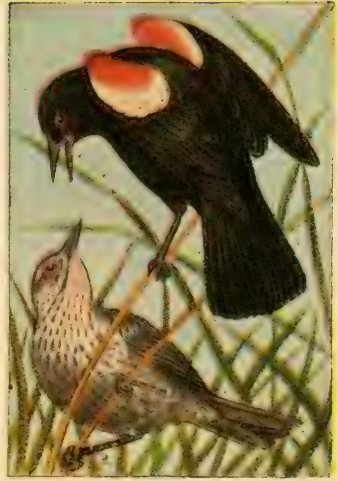

65 


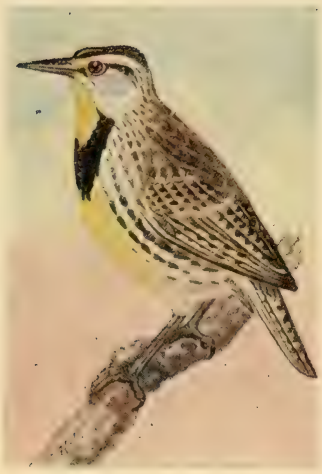

$6 i j$

\section{MEADOWLARK.}

501. Sturnella magna. $10 \% / 4$ inches.

Meadowlarks are familiar friends of the hillside and meadow; their clear fife-like whistle is often heard, while they are perched on a fence-post or tree-top, as well as their sputtering alarm note when they fly up before us as we cross the field.

Song.-A clear, flute-like "tseeu-tseeer," and a rapid sputtering alarm note.

Nest.-Of grasses, on the ground in fields, usually partially arehed over. Three to five white eggs specked with brown $(1.10 \times .80)$.

Range.- $\mathbf{T}$. A. east of the Plains and north to southcrn Canada; winters from Massachusetts and Illinois southward.

Sub-species.-501.1. Western Meadowlark (neglecta). This race has the yellow on the throat extended on the sides; its song is mueh more brilliant and varied than the eastern bird. It is found from the Plains to the Pacific. 501c. Florida Meadowlark (argutula) is smauer and darker than the common. 


\section{AUDUBON ORIOLE.}

503. Icterus melanocephalus audubonii. $9^{1 / 2}$ inches.

Within the Lnited States, these large Orioles are found only in southern Texas. They are not uneommon there and are resident. Their notes are loud, mellow whistles like those of the other Orioles. Their nests are semi-pensile and usually placed in mesquite trees not more than ten or fifteen feet from the ground.

\section{SCOTT ORIOLE.}

504. Ictcrus parisorum. 8 inches.

These beautiful birds are found in southwestern United States, from C'alifornia to western Texas.

They are said to sing more freely than other members of the family, but the song, while loud and clear, is of short duration. Their nests, which are semi-pensile, are often places in giant yucea trees, or in rines that are suspended from cacti. The three or four eggs are pale blue. scrawled and spotted with black and lavender $(.95 \times .65)$.

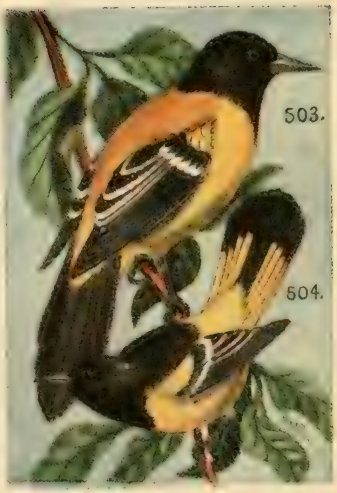

67 


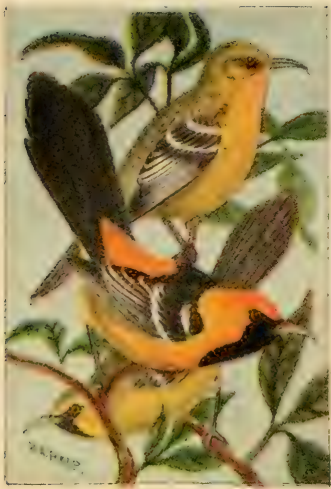

is

\section{HOODED ORIOLE.}

505. Icterus cucullatus sennetti. 8 inches.

This very brilliantly plumaged Oriole is, perhaps, the most abundant of the family in southern lexas. It is not as shy a bird as the two preceding species and is more often found in the neighborhood of houses.

With the exception of a few kinds of fruits, their food consists almost entirely of insects; all the Orioles are regarded as among our most beneficial birds.

Notes.-A harsher and more grating whistle than that of most of the Orioles.

Nest.- Lisually in bunches of hanging moss, being made by hollowing out and matting the moss together and lining it with finer wiry moss. Others are placed in rucal trees, such nests being made of the fiber of the tree. Egos dull white, scrawled about the large end with black and lavender $(.85 \times .60)$.

Range.-Found only in southern Texas. A sub. species (nelsoni) is found in New Mexico, Arizona and southern California. 


\section{ORCHARD ORIOLE.}

506. Icterus spurius. $71 / 4$ inches.

Male chestmut and black: female dull yellowish and gray: roung male, second year, like female, but with black face and throat. These Orioles are usually found in open country and, as their name suggests, have a preference for orchards. They are also found abundantly in shrubbery along streams and roadsides. They feed chiefly upon worms, caterpillars, heetles, grassioppers. ete., and are one of the most beneficial birds that we have.

Song.-A rich, loud and rapid warble, cheery and pleasing but impossible to describe: a chattering note of alarm.

Nest.-A beautiful basket of grasises woven into a deeply cupped ball and situated in forks of trees or bushes; often they are made of green grasses. Four to six white eggs, specked, scrawled and spotted with black and brown $(.80 \times .55)$.

Range.- $-\mathrm{U}$. S. east of the Plains, breeding from the Gulf to Massachusetts and Michigan; winters in Central America.

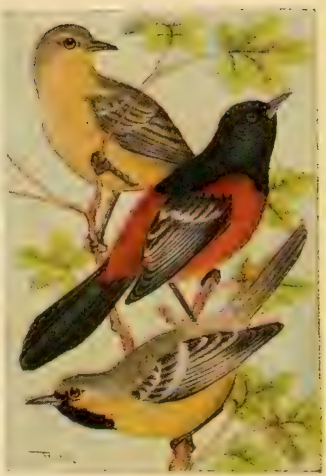

69 


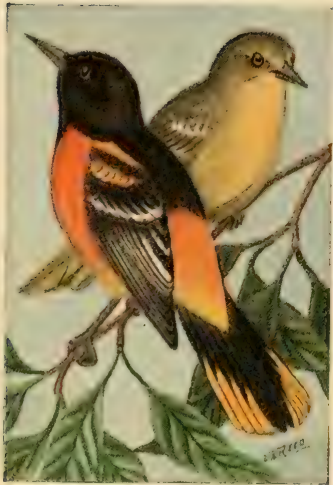

70
BALTIMORE ORIOLE.

507. Icterus galbula. $7 \frac{1}{2}$ inches.

Male orange and black; female dull yellowish and gray.

They are sociable birds and seem to like the company of mankind, for their nests are, from choice, built as near as possible to houses, often being where they can be reached from windows. As they use a great deal of string in the construction of their nests, children often get amusement by placing bright-colored pieces of yarn where the birds will get them, and wateh them weave them into their homes.

Song.-A clear, querulous, varied whistle or warble; call, a plaintive whistle.

Nest.-A pensile structure, often hanging eight or ten inches below the supporting rim, and swaying to and fro with every breeze. They lay five or six white eggs, curiously serawled with blackish brown $(.90 \times .60)$.

Range. $-\mathrm{N}$. A. east of the Rockies and breeding north to New Brunswick and Manitoba. Winters in Central America. 


\section{RUSTY BLACKBIRD.}

510. Euphagus carolinus. $9^{1} \frac{2}{2}$ inches.

Male glossy black: female grayish: both sexes in winter with most of the head and breast feathers tipped with rusty. In the Inited states we know these birds chiefly as emigrants; but a few of them remain to breed in the Northern parts. Their songs are rather squeaky eflorts, but still not ummusical. These birds are found east of the Rockies.

\section{BREWER BLACKBIRD.}

\section{Euphagus cyaneocephalus. 10 inches.}

Male with a glossy purplish head and greenish-black body: female grayish brown. This is the Western representative of the preceding; it is most abundant west of the Rockies, lut is also found on the Plains. Its distribution is not so northerly and it nests commonly in its Cnited States range. Their eggs are whitish, very profusely spotted and blotched with various shades of brown (1.x.75).

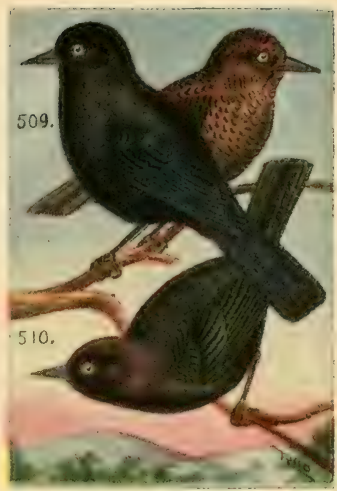




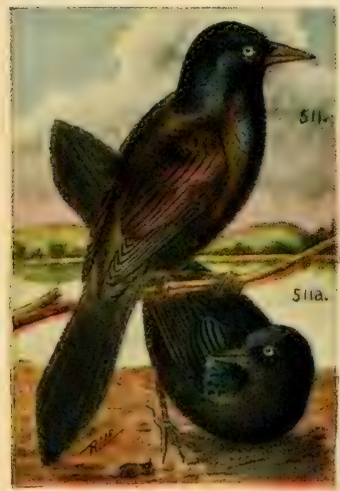

72

\section{PURPLE GRACKLE.}

511. Quiscalus quiscula. 12 inches.

Male with purple head and greenish back: female brownish gray. All the Grackles are very similar in appearance, the colors varying with different individuals of the same species. Their habits are alike, too, and I consider them one of the most destructive of our birds.

Notes.-A harsh "tehack," and a squeaky song.

Nest.-Of sticks and twigs. usually in pines in the North and bushes in the South. Four eggs, pale bluish gray with black scrawls $(1.10 \times .80)$.

Range.-Eastern [. S., breeding north to Mass.

Sub-species.-511a. Florida Grackle (agleusi, slightly smaller. 511b. Bronzed Grackle (aneus, with a purple head and usually a brassy back. Eastern U. S., breeding north to Labridor and Manitoba.

\section{BOAT-TAILED GRACKLE.}

513. Meyaquiscalus major. 15 inches.

Similar in color to the last but much larger, and hav ing the same habits. Eggs also larger $(1.25 \times .95)$. Southeastern L. S. The Great-tailed Grackle (macrourus), found in Texas, is still larger. 


\section{EVENING GROSBEAK.}

514. Hesperiphona respertina. S inches.

Fomale paler and with white on upper tail eoverts. As would be judged from the large bills that these birds have, their food consists almost entirely of seeds, with occasionally a few berries and perhaps insects. In certain localities they are not uncommon, but, except in winter, they are rare anywhere in the $\mathrm{U}$. S. and east of the Mississippi they can only be regatrded as accidental even in winter. They have been taken several times in Massachusetts. In winter they usually travel about in small bands, visiting localities where the food supply is the most abundant.

Song.-A clear Robin-like whistle; call, a short whistle.

Nest. - I flat structure of twigs and rootlets placed at low elevations in trees or bushes. Four eggs, greenish white. spotted with brown $(.90 \times .65)$.

Range.-Breeds in mountains of western British America and northwestern U. S. South and east in winter to the Mississippi and rarely farther.

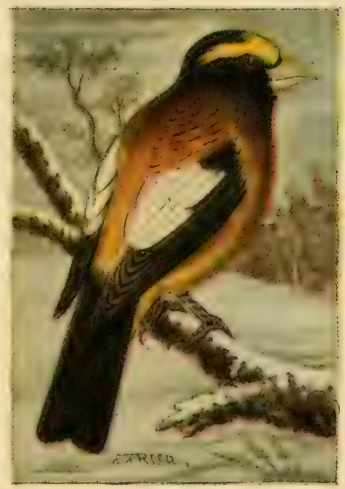




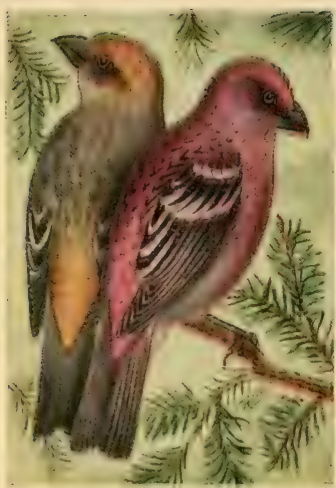

74

\section{PINE GROSBEAK.}

515. Pinicola enuclcator leucura. $\mathrm{S}^{1 / 2}$ inches. Tale rosy red; female gray and yellowish.

These pretty birds visit us every winter, coming from Canada and northern New England, where they are found in summer. They are very fearless birds and might almost be regarded as stupid: when they are feeding you can easily approach within a few feet of them, and they have often been caught in butterfly nets. They may, at times, be found in any kind of trees or woods, but they show a preference for small growth pines, where they feed upon the seeds and upon seeds of weeds that project above the snow:

Song.-A low sweet warble; call, a clear, repeated whistle.

Nest.-In coniferous trees, of twigs, rootlets and strips of bark: eggs three to four in number, greenish blue spotted with brown and lilac $(1.00 \times .70)$.

Range.-Breeds in eastern British America and northern New England: winters south to New York and Ohio. Several sub-species are found west of the Rockies. 


\section{PURPLE FINCH.}

517. C'arpodacus purpureus. 61/4 inches.

Male dull rosy red; female streaked brownish gray.

These beautiful songsters are common in the northern tier of states and in Canada. In spring the males are usually seen on, or heard from, tree tops in orehards or parks, giving forth their glad carols. They are especially musical in spring when the snow is just leaving the ground and the air is bracing. After family cares come upon them, they are quite silent, the male only occasionally indulging in a burst of song.

Song.-A loud, long-continued and very sweet warble; call, a querulous whistle.

Nest.-Of strips of bark, twigs, rootlets and grasses, placed at any height in evergreens or orchard trees. The eggs resemble, somewhat, large specimens of those of the Chipping Sparrow. They are three or four in number and are greenish blue with strong blackish specks $(.85 \times .65)$.

Range.-N. A. east of the Rockies, breeding from Pennsylvania and Illinois northward; winters through-

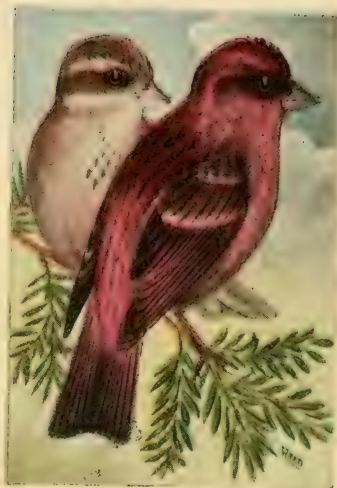




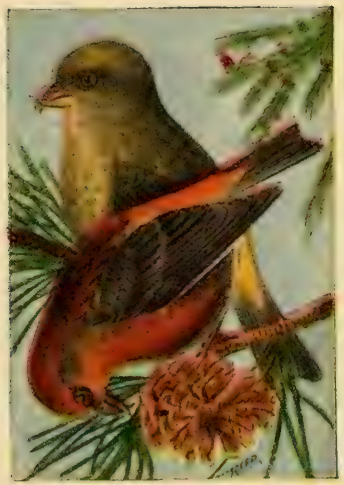

76

\section{AMERICAN CROSSBILL.}

521. Loxia currirostra minor. 6 inches. These curious creatures appear in flocks on the outskirts of our cities every winter, where they will be found almost exclusively in coniferous trees. They cling to the cones, upon which they are feeding, in every conceivable attitude, and a shower of seeds and broken cones rattling through the branches below shows that they are busily working. They are very eccentric birds and the whole flock often takes flight, without apparent cause, only to circle about again to the same trees. The flute-like whistle that they utter when in flight sounds quite pleasing when coming from all the individuals in the flock.

Song.-A low twittering; call, a short, flute-like whistle.

Nest.-In coniferous trees, of spruce twigs, shreds of bark and some moss or grass. The three or four eggs are greenish white spotted with brown $(.75 \times \mathrm{x} .55)$.

Range.-Breeds from northern New England northward and westward, and south in mountains to Georgia; winters in the northern half of the $\mathrm{L}$. S. 


\section{WHITE-WINGED CROSSBILI.}

522. Loxia leucoptera. 6 inches.

Male, rosy; female, with yellowish.

This species seems to be of a more roving disposition, and even more eccentric than the last. They are not nearly as common and are usually seen in smaller flocks: occasionally one or two individuals of this species will be found with a flock of the American Crossbills, lut they usually keep by themselves. While they may be seen in a certain locility one season, they may be absent for several seasons after, for some reason or other. They feed upon the seeds of pine cones, prying the eones open with their peeuliar bills. last.

Notes. - Do not differ appreciably from those of the

Nest.-The nesting habits of this species are like those of the last, but the eggs difler in being slightly larger and in having the markings of a more blotchy character $(.80 \times .55)$.

Range.-Breeds from the northern parts of the northern tier of states northward. Winters in the northern half of the U. S.

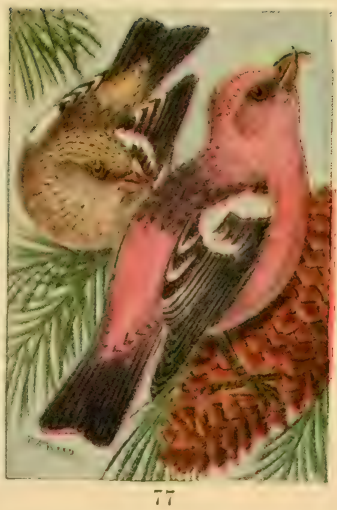




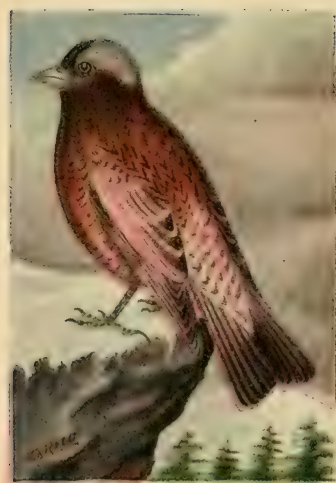

78

\section{GRAY-CROWNED LEUCOSTICTE.}

524. Leucosticte tephrocotis. $61 / 2$ inches.

Female similar to, but duller colored than the male. All the members of this genus are western and northern, this one only being found east of the Rockies and then only in winter, when it occasionally is found east of the Irississippi. They wander about in rocky mountainous regions, feeding upon seeds and berries. They are very restless and stop in a place but a short time before flying swiftly away, in a compact flock, to another feeding ground.

Note.-An alarm note of a short, quick whistle.

Nest.-Built on the ground, usually beside a rock or in a crevice; composed of weeds and grass, lined with finer grass. They lay three or four unmarked white eggs in June.

Range.-Western U. S., breeding in the higher moun tain ranges: in winter sometimes wandering east to the Mississippi. 


\section{REDPOLL.}

528. Acanthis linaria. $51 / 4$ inches.

Male with a rosy breast; female without.

In winter these northern birds may be found in tlocks gathering seeds from weeds by the roadside and stone walls. Their actions greatly resemble those of our Goldfinch, but their flight is more rapid.

Song.-Firong, sweet and canary-like.

Nest.- At low elevations in bushes or trees; eggs three to fire. pale greenish blue with brown specks.

Range.-Breeds in the extreme north; winters south to northern U. S.

Sub-species.-528a. Holboell Redpoll (holboelli), slightly larger. 528b. Greater Redpoll (rostrata), larger and darker.

\section{GREENLAND REDPOLL.}

527. Acanthis hornemunnii. (j inches.

A larger and much whiter species found in Greenland and migrating to Labrador in winter. $527 \mathrm{~b}$. Hoary Redpoll (exilipes). smaller and darker, but still lighter than the Redpoll; winters south to Massachusetts.

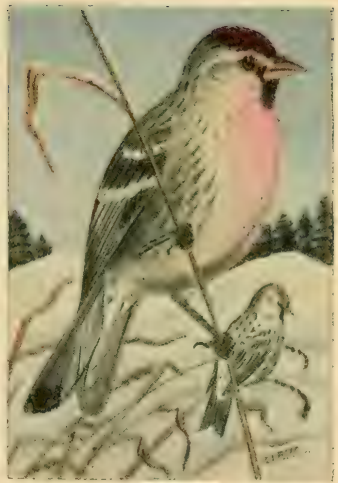

79 


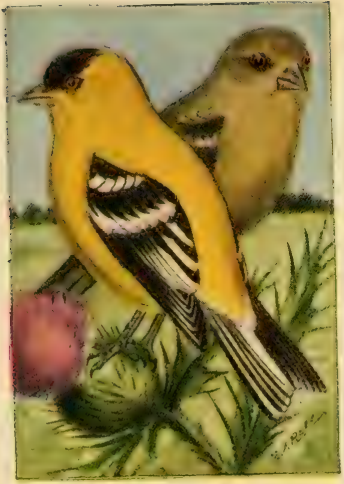

80

\section{AMERICAN GOLDFINCH.}

529. Astragulinus tristis. $5 \frac{1}{4}$ inches.

These beantiful little creatures are often known as Thistle-birds and Wild Canaries. the former name because they are often seen on thistles, from the down of which their nests are larcrely made, and the latter name because of the sweet canary-like song. Their flight is a peculiar series of undulations accompanied by an intermittent twitter. They are very sociable and breed usually in communities as well as travel in flocks in the winter. Their food is chiefly of seeds and they often come to gardens in fall and winter to partake of sunflower seeds, these flowers often being raised for the sole purpose of furnishing food for the finches in the winter.

Song.-Sweet, prolonged and canary-like; call, a musieal "tcheer," and a twittering in flight.

Nest.-Of thistle down, plant fibres and grasses, in forks of bushes. most often willows or alders near water. Four or five unmarked, pale bluish eggs.

Range.-N. A. east of the Rockies; breeds from Vir ginia and Missouri north to Labrador; winters in L. S. 


\section{WESTERN GOLDFINCH.}

530. Astragalinus psaltria. $4 \frac{1}{4}$ inches.

Cap, wings and tail black: sides of head and back greenish. Female much duller and with no black in the crown. These little Goldtinches are very abundant throughout the West. Their flight is undulatory like that of the preceding, and all their habits are lery similar. They spend the winter in bands, roving about the country, feeding on weed seeds: in summer they repart. either in small bands or by single pairs. to the edges of swamps or woodland near water. where they construct their compact homes in the forks of bushes. "Their eggs are pale blue like those of the American foldfinch, but of coulse are much smaller $(.62 \times .45)$. They are latil in May or June, or even earlier in the western portions of their range.

Song.-- Sweet and musieal, almost like that of the last species.

Range.-Western Lnited States from the Plains to the Pacific, being abundant west of the Rocky Mromtains.

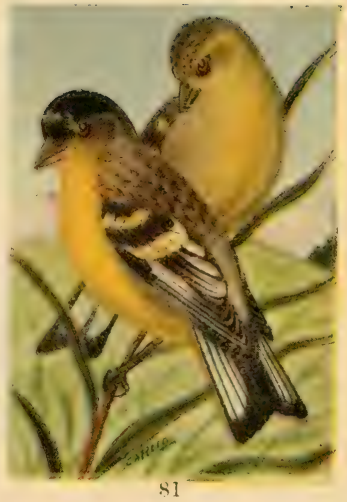




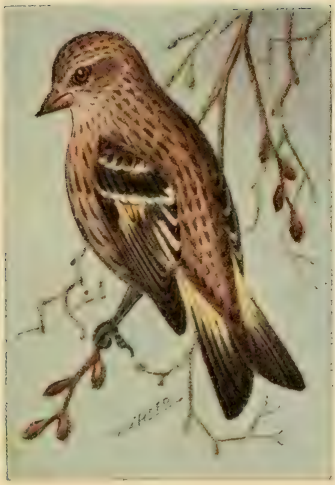

82

\section{PINE FINCH OR SISKIN.}

533. Spinus pinus. 5 inches.

These are also northern birds, being found in the U. S., with the exception of the extreme northern parts, only in winter and early spring. Their habits are just like those of the Goldfinches, for which species they are often mistaken, as the latter are dull-colored in winter. Their song and call-notes are like those of the Goldfinch, but have a slight nasal twang that will identify them at a distance, after becoming aceustomed to it. They are often seen hanging head downward from the end's of branches as they feed upon the seeds or buds, and when thus engaged they are very tame.

Song.-Quite similer to that of the Goldfinch.

Nest.-In coniterous trees at any elevation from the ground. They are made of rootlets and grasses, lined with pine needles and nair; the three to five eggs are greenish white, speckea with reddish brown $(.65 \times .45)$.

Range.-North America, breeding northward from the northern boundary of the $\mathrm{U}$. S. and farther south in mountain ranges; winters throughout the $\mathrm{U}$. S. 


\section{SNOWFLAKE.}

534. Plectrophenax niralis. 7 inches.

Adults in summer black and white; in winter, washed with brownish.

When winter storms sweep across our land, these birds blow in like true snowtlakes, settling down upon hillsides and feeding upon seeds from the weed stallis that are sure to be found above the snow somewhere. They are usually found in large flocks, and are very restless, starting up, as one bird, at the slightest noise, or continually wheeling about from one hill to another, of their own accord.

Song.-A low twittering while feeding and a short whistle when in flight.

Nest.-Of grass and moss lined with feathers and sunk in the spagnum moss with which much of Aretic America is covered. Three to five eggs, pale greenish white, specked with brown. Size $.90 \times .65$.

Range.-Breeds from Labrator and Hudson Bay northward; winters in northern Lnited States.

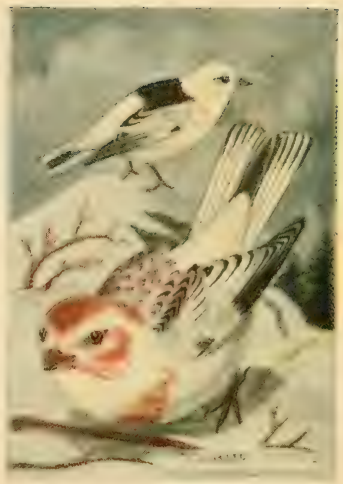




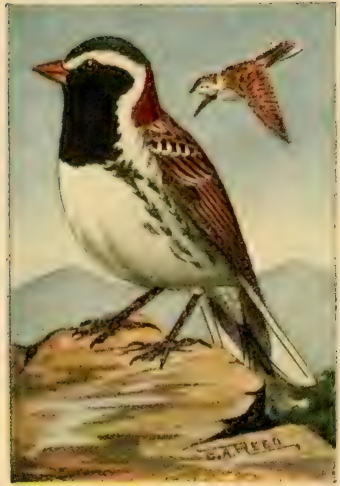

84

\section{LAPLAND LONGSPUR.}

536. Calcarius lapponicus. $6 \frac{1}{t}$ inches.

Male in summer with black crown and throat. and chestnut nape; female similar but duller; winter plumage, with feathers of head and neck tipped with grayish so as to eonceal the bright markings.

As indieated by its name, this is a Northern species, which spends the cold months in northern L. S., tras. cling in flocks and resting and feeding on side hills, often with Snowflakes, or on lower ground with Horne.I Larks.

Song.-A sweet trill or warble, frequently given while in flight; call, a sharp chip.

Nest.-Of mosses, grasses and feathers placed on the ground in tussocks or on grassy hummocks. In June and July they lay from four to six eggs having a grayish ground color, which is nearly obscured by the numerous blotehes of brown and lavender $(.80 \times .60)$.

Range.-Breeds from Labrador northward and winters south to South Carolina and Texas. A sub-species is found in the West. 


\section{SMITH LONGSPUR.}

537. Calcarius pictus. $6 \frac{1}{2}$ inches.

Male in summer with the underparts butry and sides of head marked with black: female. and male in winter, much duller with all bright markings covered with a brownish-gray wash.

Like the last species, these are Aretic birds found, in winter, on the plains and prairies of middle $[$. S. They are rarely found within our limits when in their heautiful spring plumage. They are most always found in company with the following species feeding upon seeds, buds and small berries.

Song.-A sweet warble rarely heard in the United States; a clear "cheer-up" constantly uttered while on the wing.

Nest.-Of grasses, weeds and moss, lined with feathers: located on the ground in similar locations to those of the last species. The four or five eggs are similar to those of the last but lighter $(.80 \times .60)$.

Range.-Breeds about Hudson Bay and northward; vinters in middle Lnited states.

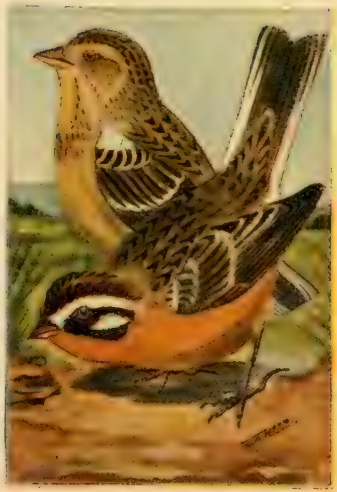

85 


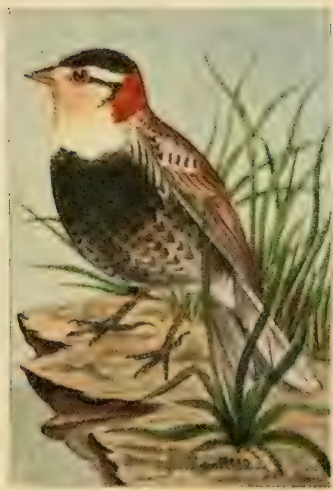

86
CHESTNUT-COLLARED LONGSPUR.

538. Calcurius ornatus. $61 / 4$ inches.

Male in summer with a black breast and erown, and rhestnut nape: female, and male in winter, much duller and with all bright markings covered with grayish.

Inlike the preceding Jongspurs, these are constant residents in the greater part of the Western Plains, in some localities being elassed as one of the most abundant birds. They have a short, sweet song that, in springtime, is frequently given as the bird mounts into the air after the fashion of the Ilorned Larkis. They commonly feed about ploughed fields, along the elges of which they build their nests.

Song. - I short. sweet trill: alarm note a sharp ehip, and call note a more musical chirp.

Nest.-Of tine grasses, placed on the ground in open prairies or along the edges of cultivated ficlds. often being concealed beside a tussock; their four or five egros are clay color marked with reddish brown and lavender $(.75 \times .55)$.

Range.-Breeds in the Great Plains from Kansas and Colorado north to Manitoba; winters south te Mexico. 


\section{IN'COWN LONGSPUR.}

539. Rhynchophanes mecomnii. 6 inches.

Male with a black crown and patch on breast, and chestnut shoulders: female, and male in winter, dull colored with all bright markings obscured by brownish gray.

These are also common birls on the plains of middle I. S., but perhaps not so much so as the last sprecies. with which species they are often found breeding. These finches show their close relationship to the? famous Skylark of Europe by frequently indulging in the same practice of soaring aloft and descending on set wings, rapturously uttering their sweet song.

Song.-A shrill, twittering warble; call a musical chirp.

Nest.-A neat (up) of grasses in a hollow in the ground on prairies or in fields. Their four to six egars are dull whitish clouded with brownish, the marking not being as distinct as in those of the last species $(.75 \times .55)$.

Range.-Breeds on the Great Plains from Kansas north to Saskatchewan; winters south to IIexico

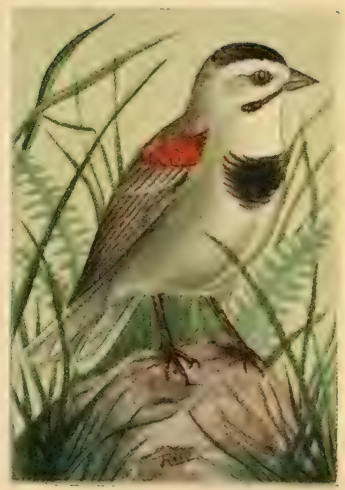

si 


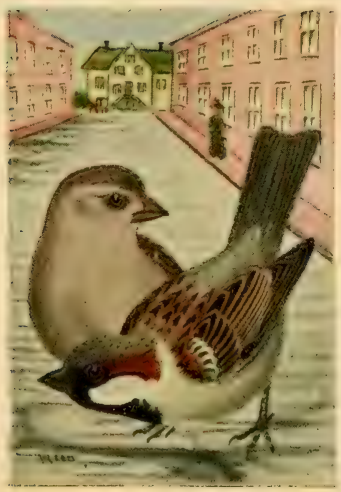

S8

\section{ENGLISH SPARROW.}

I'usser domesticuis. $61 \frac{1}{4}$ inches.

These street urchins were introduced into our country from Europe about 1850, and have since multiplied and spread out so that they now are found in all parts of our land from the Atlantic to the Pacific. Heretofore they have confined themselves chiefly in the immediate vicinity of the larger cities and towns, but it is now noted with alarm that they are apparently spreading out into the surrounding country. They are very hardy creatures, able to stand our most rigorous winters. They are fighters and bullies from the time they leave the egg, and few of our native birds will attempt to live in the neighborhood with them.

Notes.-A harsh, discordant sound, which they commence early in the morning and continue until night.

Nest.- () straw and rubbish piled behind blinds, in the tops of electric lights or crevices of buildings, and sometimes large, unsightly heaps of straw in trees. they raise three or four broods a year and in all seasons; five to seven whitish eggs seratehed with black.

Range.-Whole of L. S. and southern C'anada. 


\section{VESPER SPARROW.}

540. Poxcetes gramineus. 6 inches.

The chestmut shoulders and white outer tail feathers distinguish this from any other of our Sparrows.

The name Vesper Sparrow is given this bird because of its habit of tuning up along towards evening: it is perhaps more often known as the "Bay-winged ciparrow" or "Grass Finch."

They are found chiefly in dry pastures or along dusty roadsides, where they start from the ground in tront of us, their white tail feathers showing prominently as they fly, so that there will be no mistake as to their identity.

Song.-A clear, ascending series of whistles, given from a fence post or bush top; call, a sharp chirp.

Nest.-Of grasses in weedy fields or pastures: four or five whitish eggs marked and blotched with brownish $(.80 \times .60)$.

Range.-Eastern N. A. from Virginia to southern Canada; winters in southern U. S. The similar Western Vesper Sparrow (confinis) is found from the Plains to the Pacific coast ranges.

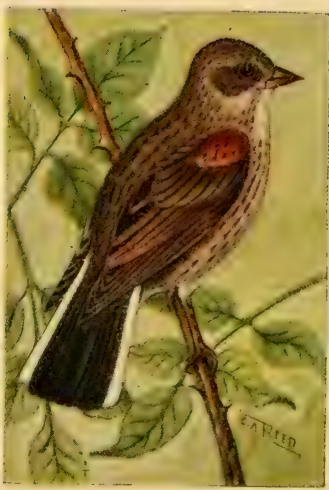

89 


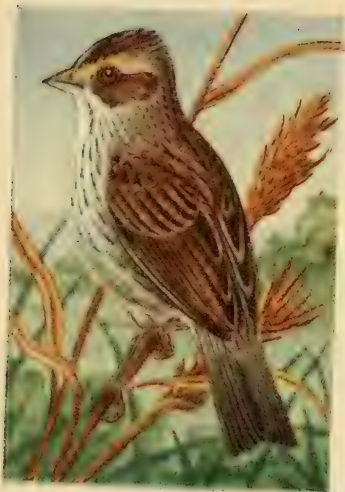

90

\section{IPSWICH SPARROW.}

541. I'asscrculus princeps. $61 / 4$ inches.

This speeies is larger and paler colored, but very similar to the more common and better known Savanna Sparrow. Its habits are the same. It breeds on Sable Island, Nova Scotia, and winters along the Atlantic coast to Virginia.

\section{SAVANNAH SPARROW.}

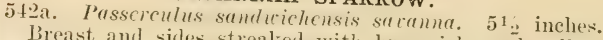
Breast and sides streaked with brownish, and rellow before the eye and also on bend of wing.

These finches are very abundant in eastern $[$. S. during migrations and a few remain in the northern parts through the summer.

Song.-A weak trill or twitter: a short chip.

Nest.-Of grasses in hollows in the ground and concealed by grass or weeds. The four grayish eggs are spotted with brown $(.75 \times .55)$.

Range.-IVinters in southern C. S.: breeds from northern $U$. S. northward. 542b. Western Savanna Sparrow (alaudinus) is found from the Plains west to the coast ranges. It is slightly paler. 


\section{BAIRD SPARROW.}

545. Ammodramus buirdi. $5^{: 3}$ inches.

Crown and nape brownish yellow streaked with black; underparts white streaked on the throat, hreast and sides with blackish; tail slightly forked and the feathers pointed.

In sumner the western plains and prairie ring with the tinkling songs of these little syarrows: they are especially abundant in Dakota and Montana.

\section{GRASSHOPPER SPARROW.}

546. Ammodramms somvmornm anstrulis. $5^{1}$. Crown blackish with a central bufî̀ stripe; nape brown and gray; sides of head. breast and tlanks, bully without streaks.

Song.-A weak, insect-like "zee-e-e-e-e."

Nest.-A grass-lined hollow in a fiolel, with the top arched over so as to keep ofl the sum and conceal the eggs. In June four or five white, brown-specked egass are laid $(.75 \times .55)$.

Range.-T. S. east of the Rockies; winters in southern U. S.

54tib. Florida Grasshopper Sparrow (floridanus), a darker race found on the plains of interior lilorida.

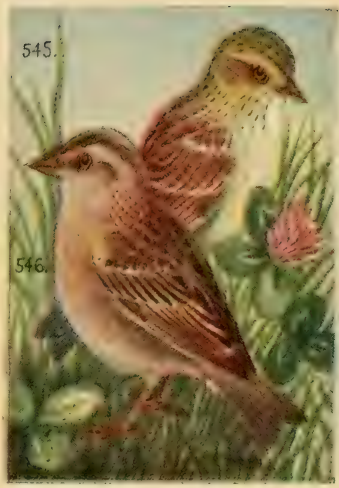

91 


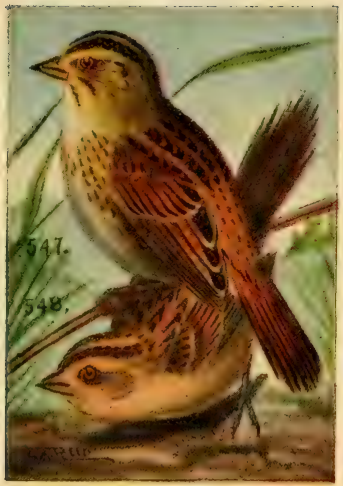

92

\section{HENSLOW SPGRROW}

547. Passerherluulus henslomii. 5 inches.

Crown and nape greenish, streaked with black; breast and sides buffy, streaked with black; tail feathers narrow and pointed.

This species is of a more southern distribution than the last, being rarely found in New England, but quite common in favorable localities south of Virginia.

\section{LECONTE SPARROW.}

545. Passerherbulus lecontei. in inches.

Hind head chestnut and gray; sides of head, throat breast and flanks a rich buff color.

Song.-A grasshopper-like squeaking.

Nest.-Of grasses in hollows of the ground on prairies; eggs greenish white thickly specked with brownisn $(.65 \times .50)$.

Range.-Breeds in the Great Plains from Dakota to Manitola, and winters southeastward to the South Atlantic and Gulf States. 


\section{SHARP-TAILED SPARROW.}

5. 49. Passertierbulus cundurutus. 5:3/4 inches.

Back of head greenish; sides of head, breast and flanks buff with black streaks; tail feathers sharp.

Salt marshes along the seacoast or along streams emptying into the ocean are the dwelling places of these finches. They creep about like mice in the salt grass, now ruming across an open space, now threading their way through the upright stalks.

Song. - I rather weak, squeaky trill.

Nest.-Of seaweed and marsh grass, attached to the griass stalks several inches above ground and often covered by a mass of dry seaweed. Eggs greenish white specked with brown $(.78 \times .56)$.

Range.-Atlantic coast of the U.S.

\section{NELSON SPARROW.}

54ta. Passerherbulus nelsomi. 51/2 inches.

Similar to the last but brighter colored and not streaked below. In the Mississippi Valley north to Manitoba. 549a. Acadian Sharp-tailed Sparrow (sub-virgatus). Atlantic coast, breeding from Maine to New Brunswick.

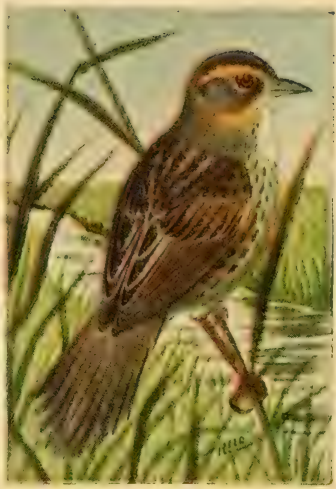

93 


\section{LARK SPARROW.}

552. Chondestes grammacus. $61 / 4$ inches.

These handsome sparrows are very abundant in the Mississippi Valley; their favorite resorts are fields, pastures and prairie lands, or along dusty roadsides. Their song is one of the sweetest of any of the sparrows, and is freely given throughout the summer.

Song. - A hurried gush of silvery tremulous notes.

Nest.- Sometimes in bushes but usually on the ground: of grasses arranged in a hollow to form a littl: cup, and usually concealed under a tuft of gratsis or bunch of elover. The birds usually rum some distance from the nest before flying, so that they are quite hard to find. They lay three to five exgs, white, specker and scrawled sparingly with blackish $(.80 \times$. $x$. (io.), wholly different from those of any other Sparrow.

Range.-Mississippi Valley, breeding from Texas to Manitobal: winters in southern [T. S. and Mexico.

Sub-species.-552a. Western Lark Sparrow (strigatus) is slightly paler and less heavily marked; found from the Plains to the Pacific.

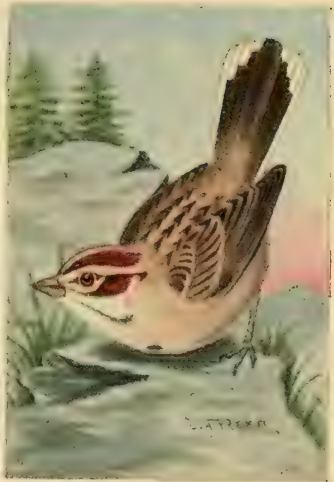




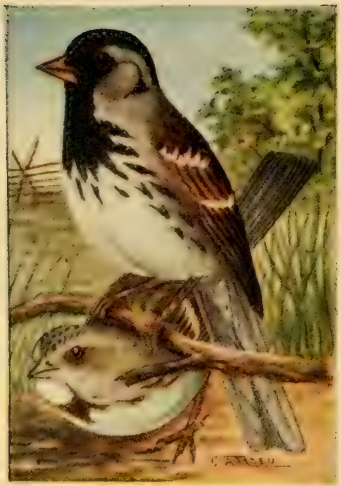

96

\section{HARRIS SPARROW.}

553. Zonotrichia querula. $71 / 2$ inches.

Adults in summer with the erown, face and throat black; in winter with the black areas mottled with gray.

This species is one of the largest of the Sparrows. It is found abundantly on the prairies during migrations, but about nesting time they all seem to disappear and no one has, as yet, been able to locate their exact breeding range. It is supposed to be among some of the foothills of North Dakota and northward through Manitobia and Saskatchewan, as they have been found during the summer in all these localities. Nests supposed to belong to this species have been found, but they lack positive identification.

Song.-A series of musical, piping whistles.

Nest.-Supposed to be of grass and bark, a few inches above the ground in weed stalks or small shrubs; eges whitish, thickly spotted with brown $(.95 \times .65)$.

Range.-Interior U. S. from Texas (in winter) north through the Plains and Mississippi to Manitoba. 
WHITE-CROWNED SPARROW.

554. Zonotrichia leucophrys. 7 inches.

Adults with a white crown bordered by black, the black covering the lores or space before the eye (the sub-species found west of the Rockies have the lores white).

We know these birds in the $T^{\top}$. S., except in mountain ranges or in the extreme northern parts. only as migrants, they then being found in brushy woodlots or along roadsides. In the north they are found in deeply wooded ravines and on side hills. While with us they rarely if ever sing, but in their summer home they have a clear tinkling song like that of the Whitethroated Sparrow, with which we see them associated here.

Song.-A clear, sweet, piping "see-dee-dee-dee-de-e;" call note a sharp chip.

Nest.- ['sually on the ground under patches of brush or hushes. The four or five egrgs are whitish profusely spotted with brown $(.90 \times .63)$.

Range.-N. A., breeding from northern U. S. nortir. ward and in high ranges south to Mexico.

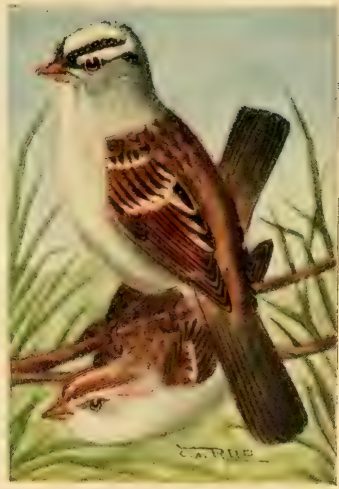

97 


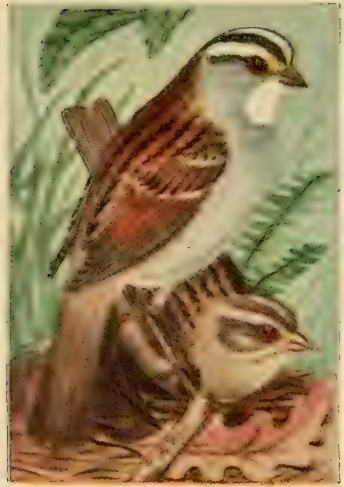

98
WHITE-THROATED SPARROW.

558. Zonotrichin albicollis. $6: 3 / 4$ inches.

In thick underbrush, we hear these birds scratching about among the leaves; oceasionally one of them will hop up on a twig and give his clear peabody song, or, hearing or seeing you, give a sharp chirp and dash out of sight again. They are birds of the ground, always busy and always hanpy. I think that without any exeeption, they are the handsomest of our sparrows, their colors are so rich and harmonize and blend together so well.

Song.-A high-pitched, very clear and sweet whistle, "pea-bo-dy-bird." (all and note of alarm, a metallie chirp.

Nest.- - Esually on the ground on the borders of woods or in swamps: of grass and leaves, similar to, but larger, than that of the Song sparrow. Four or five eggs, pale greenisl: blue. thickly spotted with brown $(.85 \times .63)$.

Range.-N. A. east of the Rockies, breeding from northern $U$. S. to Labrador and Hudson Bay; winters in the southern half of U. S. 


\section{TREE SPARROW.}

559. Spizolla monticolu. $61 / 4$ inches.

A blackish-hrown spot in middle of breast; crown reddish brown with no black about the head; back and wings with considerable brown.

These Sparrows are summer residents of the Aretic region, passing the winter in the northern laalf of the L. S. They bear considerable resemblance to our common Chipping fiparrow, but are larger and have characteristic markings as noted above. They appear in the U. S. in Octoler and many of them pass the winter in the fields and gardens in our northern states.

Note.-A musical chirp; song, strong, sweet and musical and ending in a low warble.

Nest.- - 'sually on the ground, but sometimes at low elevations in bushes. Eggs pale greenish blue with brown specks over the whole surface, thus being very ditlerent from those of the Chipping Sparrow (.80 x .60).

Range.-N. A. east of the P'lains, breeding in Labraslor and about Hudson Bay; winter's in northern half of the U. S. A sub-species, 559a. Western Tree Sparrow (ochracea) is paler; it is found from the P'lains to the Pacific, breeding in the north.

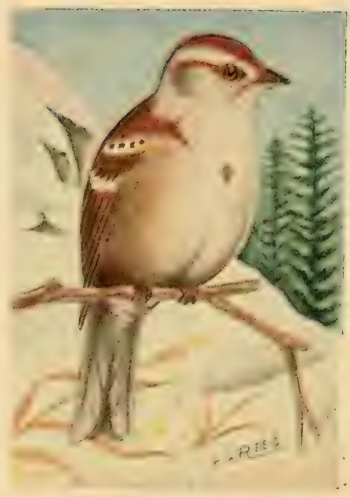

99 


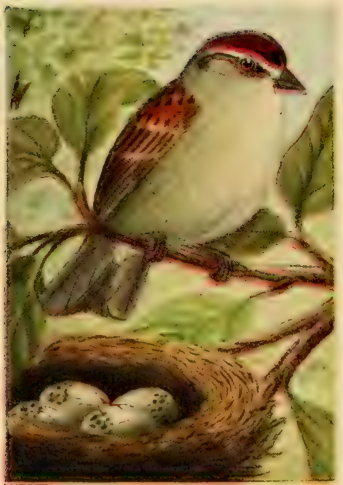

100
CHIPPING SPARROW.

560. Spizella passerina. $5 \frac{1}{4}$ inches.

Crown chestnut; forehead black; line through the eye black.

One of the commonest and most useful of our Sparrows, frequenting orchards, yards and bushy pastures. They are not at all timid and frequently nest in vines, covering porehes or the side of the house, provided that English Sparrows are not too plenty. They eat great quantities of insects and worms, and some seeds. feeding their young wholly upon the former.

Song.-A very rapidly chanted chip, chip, chip, chip, eontinued for several seconds; call, a sharp chip.

Nest.-A small cup-shaped structure of rootlets, lined with horsehair; placed in bushes, trees or vines; eggs three to five, bluish green, specked, chiefly around the large end, with blackish brown $(.65 \times .50)$.

Range.-N. A. east of the Plains, breeding from the frulf of Mexico north to Newfoundland and Hudson Bay : winters in the Gulf States. A sub-species is found west of the Rockies. 


\section{CLAY-COLORED SPARROW.}

561. Spizclla pallida. $5 \frac{1}{2} 2$ inches.

No reddish brown in the plumage: crown largely black, with a whitish stripe in centre. The habits of these birds are the same as those of the Chippy; they are ahundant on the Plains north to. Saskatehewan and breed south to the northern portion of the Inited States. They spend the winter in Mexico. Their nests and eggrs camnot be distinguished from those of the preceding, except, perhaps, by the fact that the nest has more grass than hair.

\section{BREWER SPARROW.}

\section{Spizclla breveri. $5 \frac{1}{2}$ inches.}

Like the lest species, the general tone of plumage of this is gray. It differs, though, in having the crown finely streaked with blackish. It is a more western species than the last and iv rarely found east of the Rockies. It ranges from British Columbia southward into Mexico.

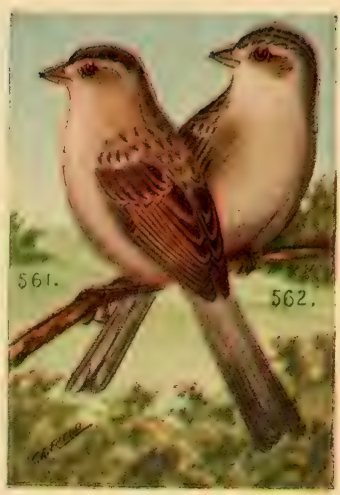

I01 


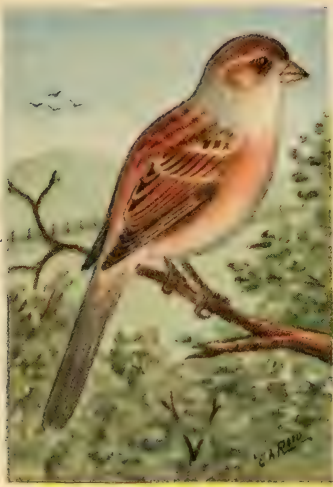

102
FIELD SPARROW.

563. Stpizella pusilla. $51 \frac{1}{2}$ inches.

Bill pinkish-brown: crown and ear covert brown with no black markings; back reddish brown and breast and sides washed with brown.

You will find these birds in dry pastures. stubble fields and side hills. The hotter and dryer a place is, the better they seem to like it. They are often the only birds that will le found nesting on tracts of land recently hurnel orer, upon which the sun beats down with stifling heat.

Song. - 1 serie's of slurill piping whistles on an asconding sale and terminating in a little trill, "silleesee-see-se-e-e."

Nest.-A frail structure of grasses and weeds, lined with finer grasses: placed either on the ground or in bushes, briars or weed patches: four or five whitish egas marked with reddish brown $(.68 \times .50)$.

Range.- lireeds from the Gulf States north to southcrn Canada: winter's in southern Inited States.

Sub-species.--563a. Western Field Sparrow (arenaceal), a praler race found on the Great Plains. 


\section{WHITE-WINGED JUNCO.}

\section{Junco ailieni. 61/2 inches.}

Slightly larger than the common eastern .Juneo, and with two white bars on the wing and more white on the tail.

This species camnot be regarded as common anywhere, even locally, and in most sections of its range it is rare. There are no peculiarities in its halits and I believe that its nests and eggs have not, as yet, been discovered.

Range.-Breels in Wyoming and the Dakotas and winters in Colorado and eastward to Kansas.

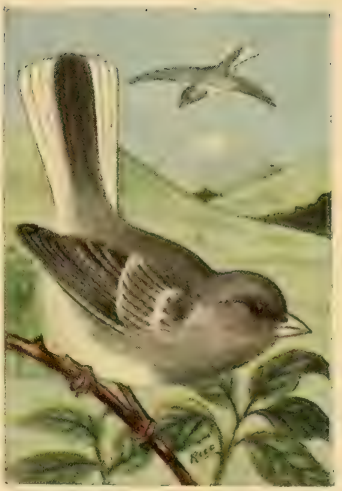

103 


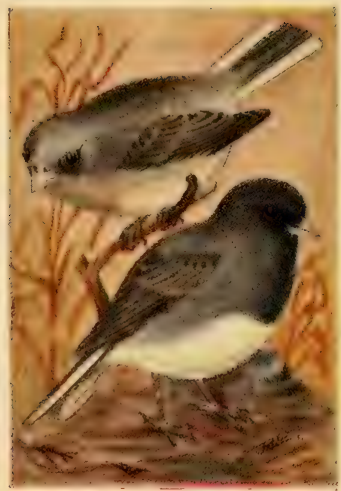

104
SLATE-COLORED JUNCO.

567. Junco hyemalis. $61 / 4$ inches.

These are one of our most common winter birds, easily recognized, while perching or on the ground, by the white or pinkish bill. and when flying by the white onter tail feathers and the gray and white plumage. They are very common about houses as well as on the edges of woids and in pine groves, being very tame and coming into the doorvard to feed upon erumbs or chaff which is often thrown out for them.

Song.-A sweet simple trill, which has a beautiful effect when given by a whole flock in unison.

Nest.-Of grasses, on the ground, usually beside a stone, in a bunch of weeds or under a small shrub, where it is well concealed. The three or four eggs are whitish, sprinkled with reddish brown $(.75 \times .55)$.

Range.-Eastern $\mathrm{X}$. A., breeding from the northern parts of the northern tier of states northward; winters south to the Gulf.

Sub-species. - j67e. (arolina Juneo (earolinensis), found in the Alleghanies from Virginia to Georgia; there are several races found west of the Rockies. 


\section{BLACK-THROATED SPARROW.}

573. Amphispiza bilincata. 51:2 inches.

These little Sparrows are entirely unlike any other North American species. They are found in the southwestern deserts, where they are not uncommon in eertain loalities, being found in mesquite or chaparral brush.

Note.-An ordinary Sparrow chip: song, a rich metallic ":iip-zip-zip-zee-zee-zee," the first three ascending, the second three notes descending.

Nest.-In bushes or cacti at low elevations; eggs plain bluish white $(.70 \times .50)$.

Range.-From Texas north to Kansas in summer. A paler sub-species, the Desert Sparrow (deserticolit), is found westward to southern California.

\section{SAGE SPARROW.}

574.1 Amplispiza nevadensis. 61/4 inches.

These hirds are found in arid regions, frementing the sage brush that is found in the Great Basin region, from western Texas to California.

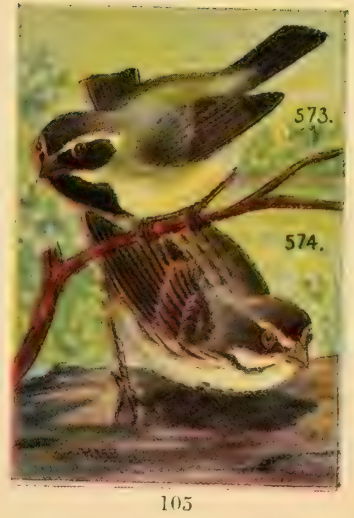




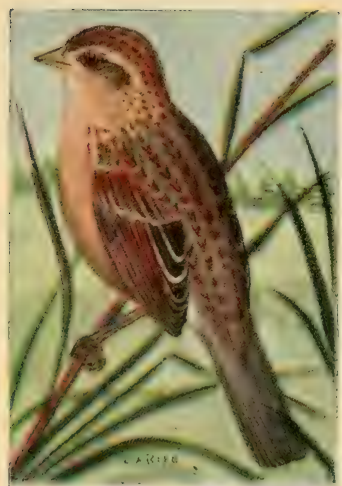

106

\section{PINE-WUODS SPARROW.}

575. Pcucal astivalis. $5 \%$ inches.

Tpper parts streaked with l,ack: hack chestnut and gray: under parts bully white: tail rounded.

These dull-eolored birds are abumdant on some of the southern pine barrens. Their habits are similar to those of the Henslow Sparrow: they are quite shy and it is almost impossible to make one show itself above the grass, through which it rums and dodges with great swiftness. If it is surprised into taking wing it goes but a few feet, then dirops ont of sight again.

Note.-A metallic chip: song, similar to that of the Field Sparrow, but reversed: that is, with the trill first. Nest.--()f grasses, on the ground, under shrubs or in fufts of grass: not usually arehed as those of Bachman Sparrow seem to always be: four or tive pure white eggs $(.72 \times .60)$.

Range.-Georgia and Florida. 575a. Bachman Sparrow (hachmamnii) is brighter ahove but has fewer black streaks: found in the South Atlantic and Gr.'f States and north to Indiana. 


\section{SONG SPARROW.}

5s1. Melosprize milutiu. $\left(i^{1}\right.$ inches.

This is probably the best known, most abundant and most widely distributed (in its numerous sub-species) of all our birch. 'I hey are quite hardy and many of them winter in the northern states, but the majority go farther south. returning to their summer lomes alont the first of March. 'They may he found anywhere where there are bushes, vines or hedges, and very often about houses, even in large cities.

Song.-lery pleatsing and musical, strongly resembling brilliant meatsmes from that of the ('anary.

Nest.-of gratsis, either on the gromel or in bushes; three to five bluish-white eggs, profusely spotted with brown $(.80 \times .58)$.

Range.-Fastern $\searrow$. A. brexling from Virginia and Missouri north to southern camala. Minters from Massachusetts and Ohin southward. Many local races are found west of the linckies, lut only one east of there. 5slj. 1)aketa Somg sparrow (judli) is found in the vicinity of Turtle Nommains. North Dakota; it is said to be lighter above and brighter below.

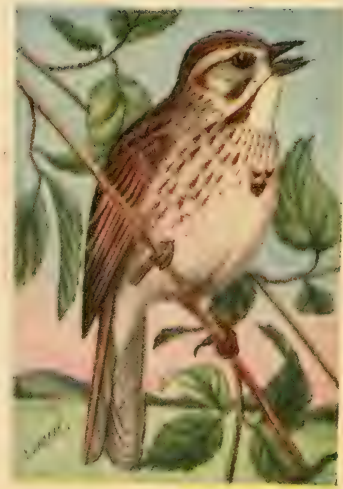

10 T 


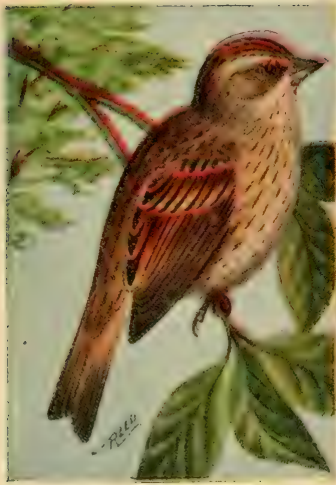

198

\section{LINCOLN SPARROW.}

583. Melospiza lincolnii. $5: 1 / 4$ inches.

Upper parts extensively brown and black: breast and sides bright buff with fine black streaks.

These flinches are quite abundant in the West, especially during migrations, lut are rather uneommon in the eastern states. Their halits are similar in some respects to both those of the Song Sparrow and of the Grasshopper Sparrow. They are very lively at all times and in the mating season quite pugnacious. 1hey sit for minutes at a time upon the top of a busn pouring forth their melody, and they have one of the most brilliant songs of any of the family.

Song.-Loud, elear and gurgling, after the style of the house Wren: eall, a metallic chirp.

Nest.-Of grass, on the ground, in tufts of grass or under small shrubs; eggs pale greenish white, heavily marked with ehestnut (.s0 $\times .58)$.

Range.-N. A.. breeding from northern I. S. to Labrador and Alaska; winters in southern half of $\mathrm{L}$. S. 


\section{SWAIMP SPARROW.}

584. Melospiza gcorgiana. 5\% inches.

Forehead hlack; crown chestnut with a gray median stripe: whole upper parts very dark; under parts grayish with brown sides.

A very quiet and unobtrusive species that dwells, as its name implies, chiefly in swamps. They creep about under the rank weeds and underbrush like so many mice; they are especially fond of the soft mires where walking is so difficult for human beings: they patter around on the soft mud with evident enjoyment, occasionally walking across an open space of water on what floating debris they may find available.

Song.- A feeble chant; call, a sharp metallic cheep.

Nest.-Of grasses, on the ground in damp places; four or five eggs, having a pale greenish-blue color heavily blotehed and clouded with shades of brown $(.90 \times .55)$.

Range.-N. A. east of the Plains, breeding from New Jersey and Missouri north to Labrador and Hudson Bay; winters in suthern half of t!e $\mathrm{U}$. S.

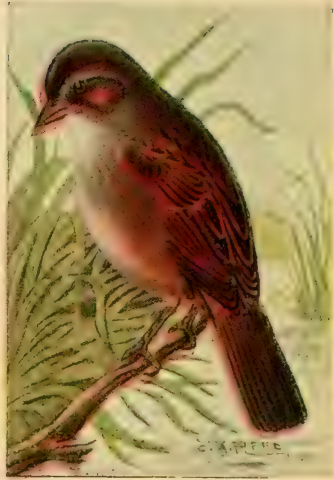

109 


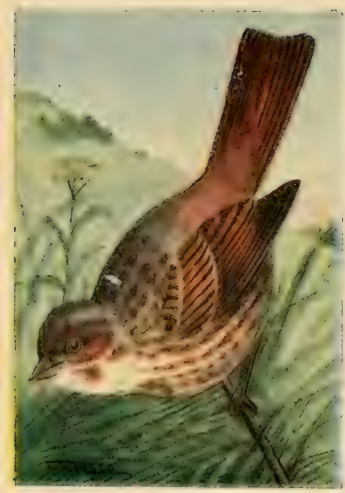

110

\section{FOX SPARROW.}

585. Passcrclla iliaca. $71 / 4$ inches.

Above bright reddish brown and gray: rump and tail wholly reddish brown, and spots on the breast and sides of the same color.

In winter we find these large Sparrows in quiet swamps and open woods, where they scratch about among the fallen leaves, after the manner of domestic fowls: they will serateh energetically for a few seernds, then pause to spe what they have uncovered. They have a short but loud and jorful song, with which they greet you on clear frosty mornings, and the effect is very beautiful when a large flock of them are singing in chorus.

Song.-A loud, elear and melodious carol; call, a soft chip.

Nest.-Of grass and moss, lined with fine grass and feathers: four or five pale bluish-green eggs, spotted with reddish brown and chestnut $(.90 \times .65)$.

Range.-N. A. east of the Rockies, breeding from New Brunswick and Manitoba northward; winters in the southern states. 


\section{TOWHEE OR CHEWINK.}

5sit. J'ipilo enthiophthalmus. \& inches.

A bird of swamps, brushy pastures and open woodlands. They are gromed birds and usually found scratching among the leaves: the male, with his black. white and hown clothes, makes a conspicmons object. while the female, with her brown and white dress. harmonizes with the leares so that it is diflicult to see her. While his mate is sitting on leer nest. the male will frequently sit in a tree top and persistently sing for many minutes at a time.

Song.-Loud and clear, "tow-hee-en"e" or "sectowhee-e-e," with the last notes tremulous: call, al sharp "cherink."

Nest.- - sually on the ground, but rarely in bushes; of strips of bark. grass and leaves: egos white with reddish-brown dots over the whole surface $(.90 \times-70)$.

Range.-Eistern $T$. A., breeding from the (iulf States to southern Canada: winters in southern $[$. S.

Sub-species.-587a. White-eved Towhee (alleni) has white eyes instead of red and less white on the tail: found on the South Atlantic coast.

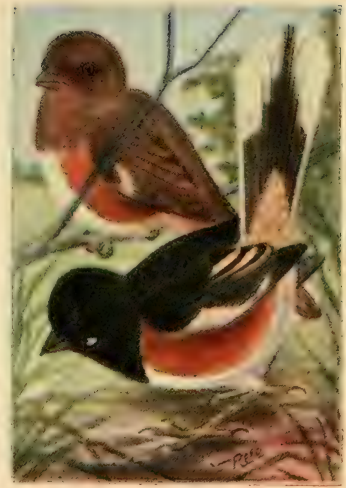

111 


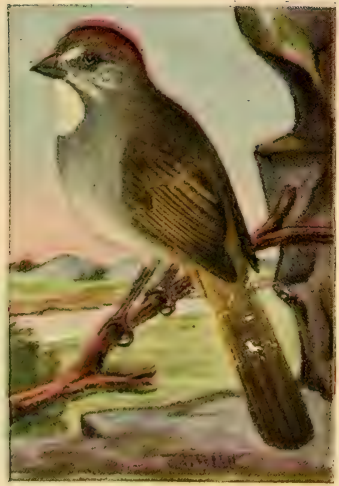

112

\section{GREEN-TAILED TOWHEE.}

592.1. Oreospiza chlorura. 7 inches.

These are characteristic birds of the Western mountains. They are typical brush birds, satistied in living a life of security in their own way, and rarely appear above the surface of the thick shrubbery except to mount to a conspicuous twig, pour forth their sweet melodies and then retreat again.

Notes.-A loul ehip; a soft, mewing note; song, finch-like, musical but rather simple.

Nest.-Fither on the ground or in bushes near the ground. Made of grasses the same as that of any of the sparrows. Eggs pale bluish gray, thickly speckled with reddish brown. The nests are huilt in very thickly tangled underbrush and are difficult to locate.

Range.-Western Lnited States, from the eastern hase of the Rockies west to the eastern slope of the Sierra Nevadas. 
CARDINAL.

5!)3. ("ardinalis rardinalis. 9 inches

Noble in carriage, beatutiful of plumage, amiable in disposition and excellent singers ante some of the qualifications of these large-billed birds. They are somthern bircls, rarely seen in northern [. S. unlesis in cagess. for large numbers of them are trapjest for this purpese. al

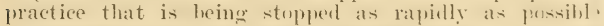
hy enforeing the laws which protect them. They aro inardy birds, often passing the winter in the northern parts of their range when the ground is everend with snow. They frequent andens, plantations ant opun woods, where they glean their foot of seeds. Berries, fruit and insects.

Song.-1 loud, elear and lirely wathe: call, a low ship.

Nest.-A frail structure of twigc, in thickets or bushes: eggs greenish lulue with reddish-brown spots $(1.00 \times .73)$.

Range.-Resident and breerling from the (inlf to New York and Inwa. 50:?. Florida C'artimal (1loridanus) is supposed to be slightly smaller and brighter.

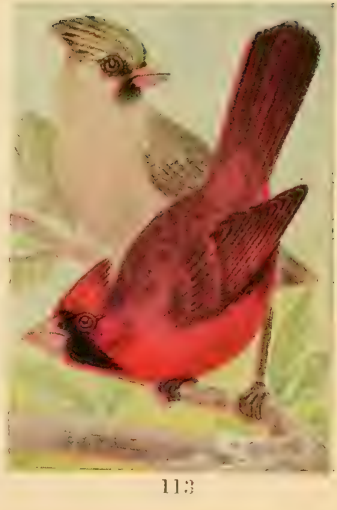




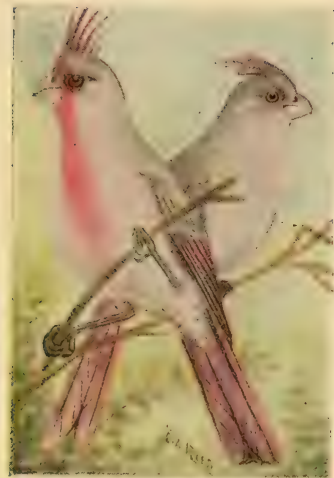

114

\section{TEXAN CARDINAL; PYRRHULOXIA.}

594a. Pyrrhuloxia sinuata texcnsis. $81 / 2$ inches.

Notice that the bill of this species is very stout and short, more like that of a parrot. The crest is also composed of fewer feathers than that of the Cardinal. It is only in the highest of plumages that the red on the underparts is continuous from bill to tail; usually it is broken into patches. The female is much duller in color than the male, but always has a strong tinge of rose color. They frequent more open and exposed positions than do Cardinals and are more shy in their disposition.

Nest.-Shabby platforms of twigs and grasses placed at low elevations in thickets. The three or four eggs are whitish, specked with dark brown, most profusely at the large end $(.90 \times .70)$.

Range.-Abundant in the Lower Rio Grande Valley in southern Texas. 


\section{ROSE-BREASTED GROSBEAK.}

595. Zamelodia ludoriciuna. 8 inches.

Mile. black and white with rose breast and under wing coverts; female resembling a large striped sparrow in color.

The center of abundance of these beantiful creatures is in the northern half of eastern L. S. In leauty and song he fully atones for what we northerners lise becanse of the southerly distribution of the Cardinal. The find them in swamps. small patches of woods, and. sometimes, in orchards. They are rather quiet birds, that is they do not move about much, lut they can ealsily be found by their song.

Song.-A rich, full. whistling carol. almost without exeeption immediately preceded with a sharp chip. Call, a deep-toned chirp.

Nest.-A loose, frail cradle of twigs at low elevations in trees or thickets: aggs bluish green spotted with brown $(1.00 \times .75)$.

Range.- - S. Salst of the Rockies, breeding in the northern half and in southern Canada: winters in Central America.

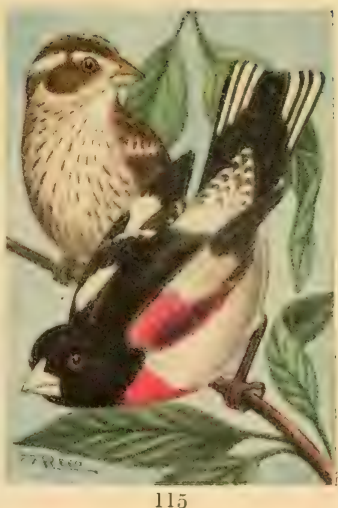

115 


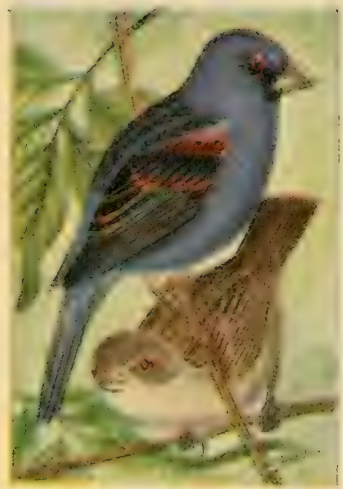

116

\section{BLUE GROSBEAK.}

597. Guiraca ecrulea. 7 inches.

Male, deep blue with chestnut shoulders: female. grayish brown alwo and grayish white helow.

(j)en woods. small groves and roadsides are the loeations in which these birds will be apt to be fomml. In some plates they are farly common. but nowhere abmelant. Their habits are very similar to those of the Rose-breasted Grosbeak.

Song.-I rapid varied warble, similar to hut louder and stronger than that of the Indigo Bunting.

Nest.-Of twigs. weeds and gratses. lined with fine rootlets: places in thickets. bushes or low trees: four or five plain hluish-white enge (.s.5 $x$.62).

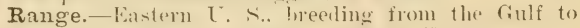
Maryland and Illinois: winters suth of $C^{2}$. S.

Sub-species. -597a. Wustern Phe Grosbeak (lat2ula). Male of a hrighter shade of blue than the east-

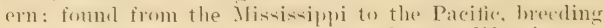
nortlı to Kinnsas. (olorado and northern (alifornia. 


\section{INDIGO BUNTING.}

598. Pusserinu a!nuru. 5ín unches.

Male, incligo blue: female. bownish but nsually with at fomt indeation of blue on the wings or tail.

I jolly summer songater, dwelling with us from the latter part of lary until heptember. Yon will meet with these Jumtings along road-ides lined with somblus trees or buskes. or in pastures or along the eilges of swamps. The male mollally lats some favorite pereh upou which les spents a large portion of his time singing: it is nearly alway the top of a tall hush or tree.

Song:- I sirightly little warble with mimy camarylike notes. Call, a sharp chip.

Nest. - Of grasses at low elevations in shruls or busles: egess four or tive in number. very pale bluish white $(.75 \times .52)$.

Range.- [ . S. east of the liockies, and most ahmdant east of the Mississippi: bresk north to Manitobu ind New Brunswick; winters in Central Americar.

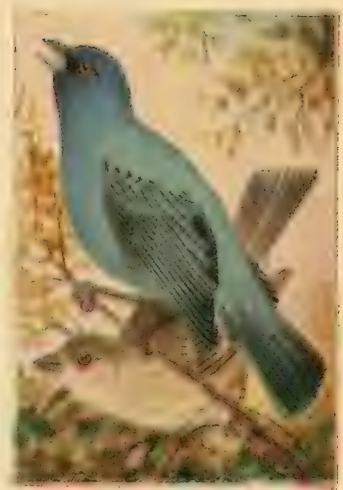

117 


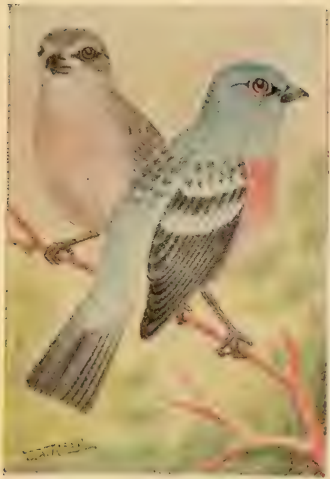

118

\section{IAZULI BUNTING.}

599. Passerina amoonu. $5 \frac{1}{1 / 2}$ inches.

This species replaces the preceding one went of the Plains. While the plumage of the males is entirely distinctive, that of the females is often confusing. The present species has quite a conspicuous band of rusty buil across the breast and lacks any sign of stripes on the sicles. such as show faintly on the last species. Its habits are just like those of the Indigo and it frequerts the same kind of territory.

Nest.-Built in a bush or on the lower branches of trees. only a few feet from the ground. The eggs are rery pale bluish white $(.75 \times 58)$.

Range.- Western Inited States from the Great Plains to the Parcific coast: north along the coast to British Columbia; south in winter to IIexico. 


\section{VARIED BUNTING.}

600. Passcrina rersicolor. $5 \frac{1}{2}$ inches.

This beatiful species is less common than any others of the genus and has a very restricted ramge in the United States. The plumage of the male birds varies a great deal; that shown in the accompanying illustration is from a.brightly colored specimen. They will average duller than this. These birds frequent thickets (r) brush-studded pasture land. Their song is deseribed as weaker than that of the Indigo Bunting, but having much of the same character.

Nest.-Built of grasses, bark and fine rootlets: a enp-shaped structure placed in forks of bushes. usually in tangled thickets. The three or four eggs camnot be distinguished from those of the last species.

Range.-The Lower Rio Grancle Valley in southern Texas. A sub-species (pulchra) is also found in Lower California and southern Arizona.

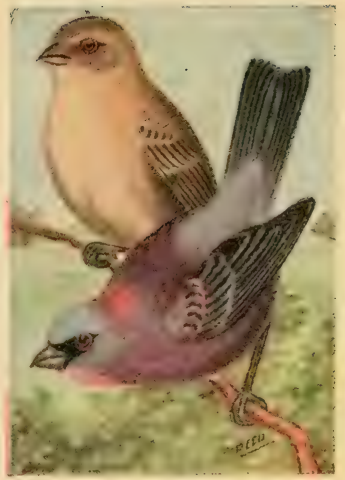

119 


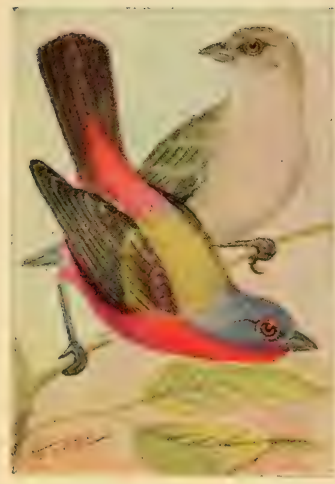

120

\section{PAINTED BUNTING.}

601. Passcrina ciris. $5 \frac{1}{2}$ inches.

Male, vari-colored: female. greenish gray.

Without any exception, the-e are the most gaudily plumaged North American birds, but their colors have a harshness of contrant that renders them far less pleasing to the eve than many others of our birds. They are witon eaged, but in eonfinement soon lese the natimal brillianey of their plumage. Like the Indigo Bunting, they are foumd in thickets and hedges; their hablits serm (o) be precisely like those of the last species. Song.- - imilar to that of the Indigo but lacking the brilliancy of that of the latter lirel.

Nest.- Of grasses, leaves, strips of hark and rootlets, compactly compressed and woren together, situated at low elevations in thickets and low bushes; egrs whitish. specked and blotehed with reddish brown $(.7 \mathrm{~s} \mathrm{x}$ $.58)$.

Range.-Goutheastern I*. S.. breeding from the Gulf north to Virginia, Ohio and Liansas; winter's in Central America. 


\section{MORELLET SEED-EATER.}

602. Sporcplita morclicti sharpi. 41:3 inches.

The male of thi interesting little species requires at least three years in which to obtain the perfect plumage as shown in our illustration. The majority of birds seen will he in intermediate stages of plumage between that of the atuld female and this one. These little fellows are usually foumd in thickets or patches of briars and are quite tame.

Note.-During the meerling seation the male has a sprightly song similar to that of the Indigo Bunting.

Nest.-The ne-ts are male of fine gratss and placed in bushes or romg trees. The egos are bluish green spotte l rather erenly with hrown (.65) $\mathrm{x} .48$ ).

Range.-Coutheaistern Texis and southward into Mexico.

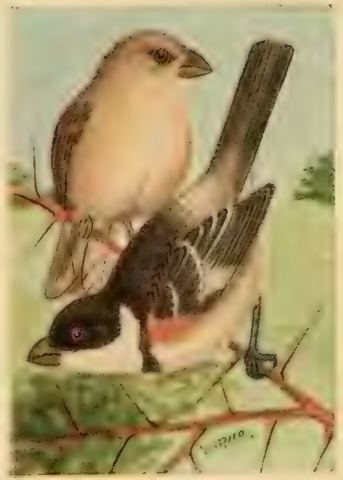

121 


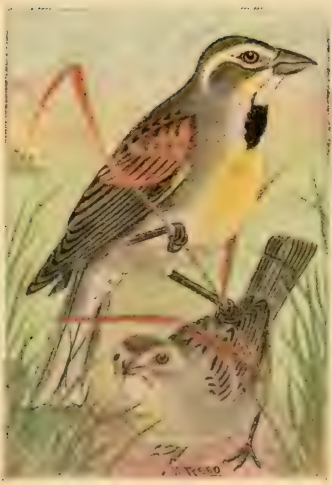

122

\section{DICKCISSEL.}

604. Spiaa americana. $6 \frac{1}{4}$ inches.

Male beautifully blended with vellow, white and gray, and with a black throat pateh and brown shoulders; female duller.

In the middle portions of the $\mathrm{L}$. S. these birds, or Black-throated Buntings, as they are commonly called, are very numerous, frequenting dry, bushy fields or prairies. They are very persistent songsters, although their song is weak and has little melody. In July and August, when many birds are silent, they continue their plaintive chant even on the most sultry days.

Song.-A simple chanting "chip, chip, che-che-che."

Nest.-Either on the ground. in bushes or thistles, or in trees: of weeds, grasses, rootlets, corn husks, ete.; eggs four or five in number, plain bluish white and hardly distinguishable from those of the Bluebird; size $.80 \times .60$.

Range.-N. A. east of the Rockies, breeding from the fulf states north to northern [. S.; rare in the Atlantic States nort's to Commecticut. 


\section{LARK BUNTING.}

(60).5. Caltomospiza melanucorys. T inches. Male, black and white: female, brown and gray. This species is often known as the White-winged Blackbird, not because it bears any resemblance to any of the Blackbirds, nor because any of the hahits are the same, hut simply because of its plumage. They are very gregurious and usually fly in llocks even in nesting timie.

They seem to be very methodical ani well trained; it one of at flock takes wing. the entire flock rises simultaneously and in a very compact borly they fly until some leader chooses the next stopping place, when they as suldenly alight. They have the halsit of Skylarks in momting into the air while singing and then descending on set wings.

Song.-A very lively. sweetly molulated warble.

Nest.-(On the ground. usually unler a tuft of grass or small bush: four or five egges of a bluish color (.85 $\mathrm{x} .65$ ), brighter than those of the Dickcissel.

Range.-Western [.. S... most abundant from Kansas to Colorato and north to Assiniboia.

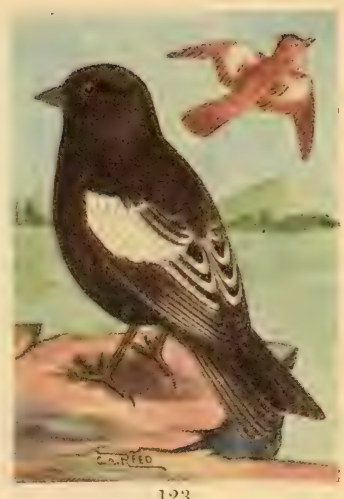

123 


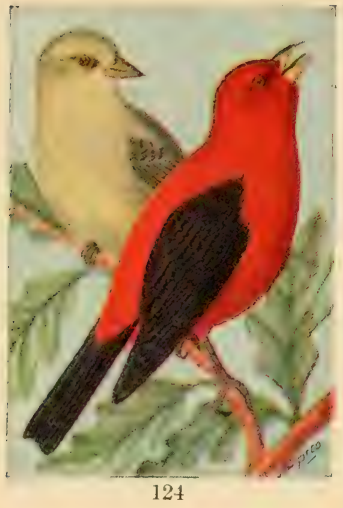

SCARLET TANAGER.

605. Piranga erythromelas. 71,2 inches.

Male, searlet and black; female, greenish yellow and blackish.

These beautiful birls are found in open worls, but they often come ont in ficlds, parks, orcharils and sometimes in yards when feeling; one of the prettiest sights that I ever saw was of alout a dozen of these binds tripping alone the furrows of a ploughed field, where they were feeding on insects. Besides herries and feets, they live upon quantities of insects, freyuently catching them on the wing in true Fiycatcher style.

Song.-Resembling that of the liobin, hut harsher, less varied and higher pitcher. Call, a sharp (hip or "chip-churr."

Nest.-Loosely made of twigs and rootlets, on luwer bramches of trees; eggs four, pale bluish green, spotted with brown $(.95 \times .65)$.

Range.-Breerls in the northern parts of the I. S. from the Atlantic to the Plains; winters in the tropices, whence it arrives about May 15. 


\section{SUMMER TANAGER.}

\section{Piranga mubra. $71 / 2$ inches.}

Male, rosy redi female, enemish yellow.

These Tanateres have a more southerly distribution than the sarlet variety, but are fomel in the some kimb of teritory. In its localities it is ratleer more ahumbant and less retiring than is the lattere bird in the north. and more of ten dwell- in public porks. This bird is often called the liedbird and in lecalitise where both the saratet Tamager and this spereses are fomd. they are frepuently known by the same name, :s their habits and notes are similar.

Song. - Cimilar to that of the searlet Tamager lout salid to be swerter and elearer, and to mere nearly resemble that of the Robin.

Nest. - In the outer horizontal limbs of trees in open woods or growes: nest of twigs and rootlets: expes bluish green, sproted with brown (.9.5 $x$. (ii,)

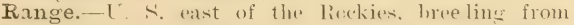
the fiulf to ver ferser and Kansats: wintere in fentral America. I subspecies is fomm west ef the linckies.

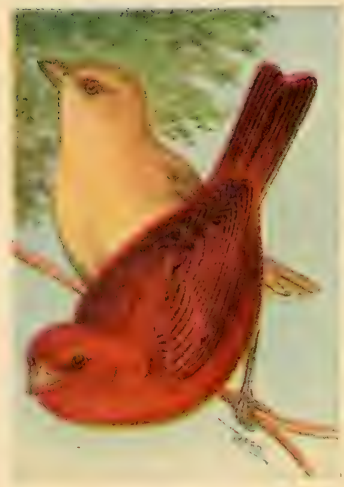

125 


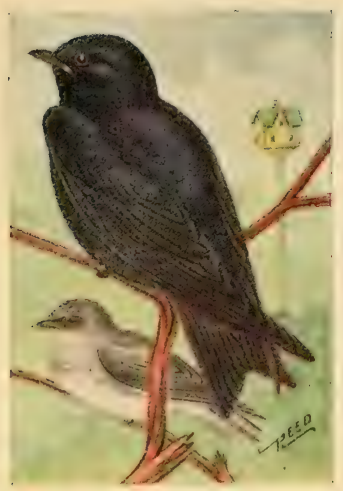

126

\section{PURPLE MARTIN.}

611. Progne subis. $7: \mathrm{g} / \mathrm{inches.}$

Male, l, he black: female, dull black and grayish.

These large, jolly swallows are commonly seen about eities and towns within their range. Originally they dwelt in lollow trees, and some do ret. but the majority have recognized the superiority of man's dwelling and now live in houses built especially for them or in cornices of houses or barns. It is no uncommon sight to see a handsome gabled structure of many rooms, perched upon a twelve-foot pole, on the lawns of many wealthy residents; others less bountifully supplicel with this world's goods use plain soap boxes for the same purpose, and the Martins seem to like the one as well as the other.

Song.-1 strong. varied grating warble or twitter. more forcible than melodious.

Nest.- If straw. paper, rags, etc., in hird houses, gables or hollow trees: engs dull white $(.98 \times 1.72)$.

Range.- $\times$. A.. breeding from the Gulf to New Brunswick and Saskatehewan: winters in northern South America. 


\section{CLIFF SWALLOW.}

612. Petrochelidon lunifrons. $51 \frac{1}{2}$ inches.

Adults similar in plumage but the female slightly paler. Easily distinguished from the Barn Swallow by the square tail and light buffy forehead and rump.

This is what is commonly called the Eare Swallow in the East, because of its habit of plastering its nests on the outside of barns or other buildings, up under the eaves. In the West they usually resort to cliffs where, sometimes, large sections of the face will be completely covered with the little mud flasks; often colonies of sereral thousand will build their nests together.

Song.-A continuous twitter, uttered while on the wing or at rest.

Nest.-A tlask or gourd-shaped structure of mud, lined with straw and feathers, attached under the eaves to the outside of buildings or on the faces of clifts; five to seven eggs are laid: white dotted and spotted with redlish brown $(.80 \times .55)$.

Range.-N. A., breeding from the Gulf to Greenland and Alaska; winters in the Tropies.

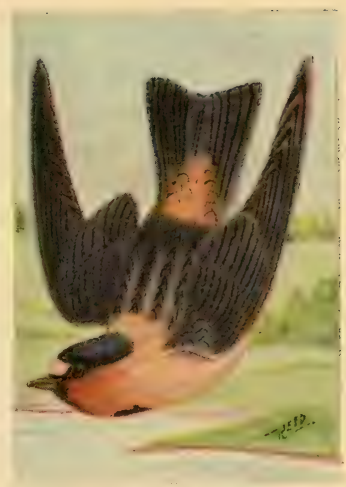

127 


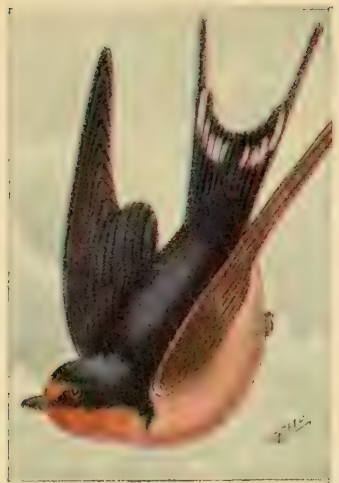

128

\section{BARN SWALLOW.}

61:). Hirundo erythrogastra. 7122 inches.

Female duller plumaged and with a less deeply forked tail than the male. Forehead and throat chestnut and entire under parts buffy; tail deeply forked and with a white spot on the inner web of each feather except the central pair.

This is the most graceful and beautiful of all our swallows, and is the most common about farm houses, the inside beams and rafters of which they appropriate for their own use. They delight in skimming over the rolling meadows or the surtace of ponds, now rising with the wind, now swooping downward with the speed of an arrow.

Song. - A continuous, rapid twitter.

Nest. - A bowl-shaped structure made up of pellets of mud cemented together with the birds' saliva, and lined with feathers; attached to rafters in latrns, the opening being at the top and not at the side as in the last; eggy exactly like those of the last.

Range.-N. A., breenling north to the limit of trees; winters in northern south America. 


\section{TREE SWALIOW.}

614. Iridoprocne bicolor. 6 inches.

IIale. sterly hlue or gresuish aluere: fomale, duller and often plain graty alore, lut both sexes always antirely white below.

Thes: swallows are al-o alumelant alont farmvards: except when they are skimming orer ponds. they are almost alwars serming the air alowe lublumes or

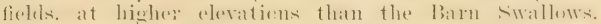
When weary tleer reast on deard twigs or telephome wires. humbleds often leximes seen in roms me the latter. I.ike the Martins, tluse birels frequently uret in lirel bexes, but watally not more than one ar two patrs in a single liouse.

Notes.-I twittering like that of the other ival. lows.

Nest.-of Grass. lined with foatlexs, in lonllow trees

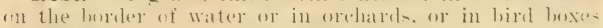
erected for their use: exps white $1.7 .5 \times .52)$

Range.-liverds in the northerm half of the $\mathcal{L}$. S. and northwarel to Labrator ame Alaskat wintors in southern U. S. and southward.

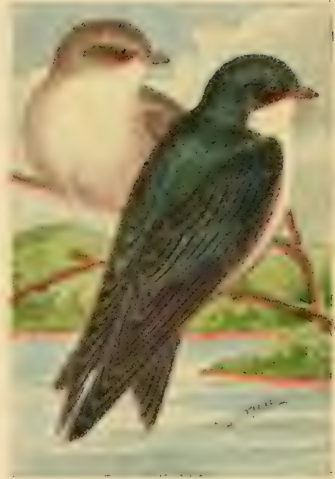

129 


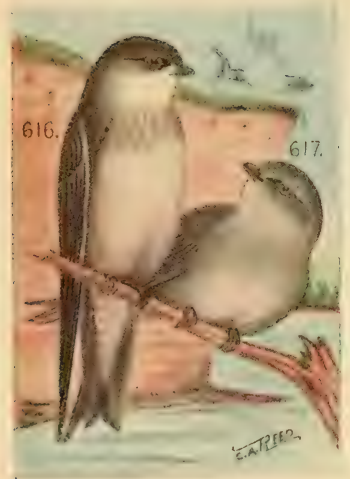

130

\section{BANK SWALLOW.}

616. Riparia riparia. $5^{1 / 4}$ inches.

These are the smallest of our Swallows; this species can be distinguished, even at a distance, by the conspicuous band across the breast, showing in hold relief agianst the lighter throat. They are found throughout North America, breeding from the middle of the $t$. 5 . north to the Aretic regions.

They nest in colonies in holes in banks, laying the four to seven white eggs on a grass nest in an enlarged chamber at the end of the tummel.

\section{ROUGH-WINGED SWALLOW.}

617. Stelgidopteryx serripennis. 512.2 inches.

In this species the throat is gray as well as the breast. The outer vane of the outer primary is stifl and bristly, thus giving the spocies its name. These birds breed from the fiulf north to Massachusetts and Washington, in hanks or in crevices of stone bridges. The eggs cannot with eertainty be distinguished from those of the l:nk Swallow. They measure $.75 \times 5.52$. 


\section{BOHEIMIAN WAXWING.}

618. Bombycilla yarmla. 8 inches.

Larger and grayer than our common Cedar Waxwing and with yellow and white on the wing: it is a northern species and is only casually found in eastern L. S. They nest within the Aretic Circle and only a few of their nests have ever been found. In winter they are found in llocks, roving restlesisly about the cointry, often alpearing where least expected and utterly deserting other places where they are usually found."

Nest. - Of small twigs and moss. lined with featlers, usually placed at low elevations in spruce or coniferous trees: egogs dull hluish white specked sparingly with black $(1.00 \times .70)$, similar to those of the ceclar Waxwing but larger.

Range.- Northern parts of the northern hemisphere, breeding within the Aretio ('ircle and wintering casmally south to Massachusetts. Pennsylvania, Kansas and California.

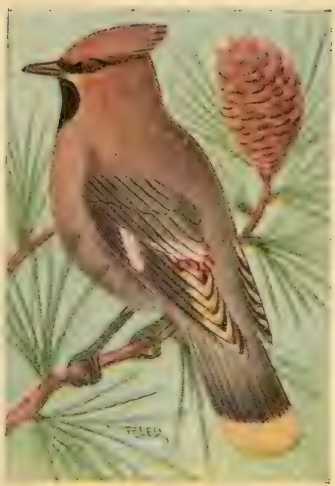

131 


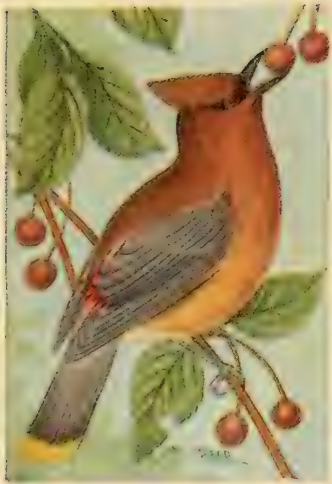

$1: 3$

\section{CEDAR WAXWING.}

\section{Bombucilla colrorum. 7 inches.}

Plumage very soft colored with a general brownish tone. shatding io gray on the rump. The Waxwings are nomed from the curious wax-like appendages at tarded to the tips of the secombaries, and rarely to the tail feathers. They are rery sociable and usially fow in flocks. They live dhietly mpon fruit and are experally foul of cherries. for which reason they are

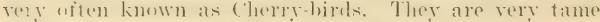
and allow anyone on almost tomeh them while they are feeding or sitting upon their nests.

Note.-In insignifiant lisping hiss.

Nest.-1 sil istintial structure of twigs, mosees. fwine, etr.. linenl with fine gratsuses placed in cedar.

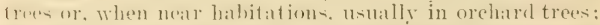
the fom or tive mogs are dull bluish white, sperked with black $(.85 \times .60)$.

Range.-N. A. breeling from Tiruinia. Miswouri and nurthern falifornia north to Labrador and sonthern ilaskat winters thomenome the lnited states. 


\section{NORTHERN SHRIKE.}

621. Lanius borealis. 10 inches.

This shrike is larger than any of the speeies found in summer in the Enited fitates and has the breast quite distinctly barred.

Shrikes are crutel, rapacions and arnivorons birds, fereting upon insects, entashoppers, lizarils and small birds. As they have palsserine feet. the same as ail oux small hirds. they are mable to hold their prey between the foet while tearing it to piocess so they impale it mpon thoms or the barbs of a wires fences, so ther may tear it to shreds with their hooked hill.

Song.-laul suatches consisting of villous whistles and imitations sugerenting that of a ('athird.

Nest.-They lireed chiefly north of the ['. S., placing their rude, bulky structures of twigs and weeds in thorny trees or hedges: their four to six eggs are grayish white with spots of light brown and clarker gray $(1.08 \times .80)$.

Range. $-\mathrm{N}$. I. Ireeling chiefly in the northern parts of f'anada: winters soutl to Pennstrania, Kansas and California.

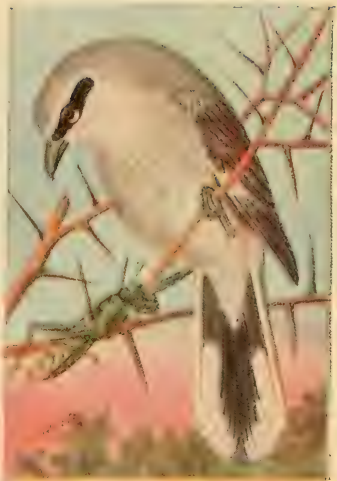

133 


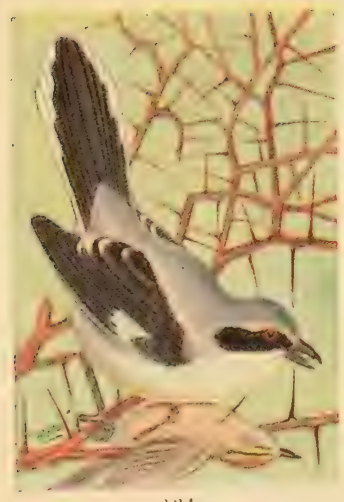

134

\section{LOGGERHEAD SHRIKE.}

622. Lanius ludoricianus. 9 inchers.

Pure white below and with the markings ahove, intense black instead of the brownish or grayish black uf the last species. Although smaller, these Shrikes have the stme destructive habits of the northern species. All the shrikes do considerable gond to mankind, for they eat quantities of grasihoppers and mice, and probably resort to their diet of small bires when other fond is mumsually searee. It camnot be denied that they are cruel. for they often kill more than they ean eat aml leave it impaled on thorms to decar.

Song.- If hatrsh, diseordint whistles.

Nest.--In scrubby hederes and thickets: of twigs. weech. leares, ete. e egrgs four to seren in number. grayish white. spotted with shades of brown aml gray.

Range.-Eistern L. S.. breeding from the Ciulf to sonthern New England and Manitoba: winters in southern siates.

Sub-species.-62.2a. White-rmmed Shrike (exeulitoridese). paler and with a white rump: found from the Plains to the Pacific in the I. S. 


\section{RED-EYED VIREO.}

624. Tiressiflea olivacia. 6 inches.

Crown slaty gray with a black border: white stripe above eye; eye reddish brown.

Throughout the Lnited States this is one of the most abundant of the family. All through the spring and summer months their warble is heard irom wondland and roadside. often beeming so monetomoun ats to be irritating. Oftentimes during the spring migrations of Warblers, Vireos are so numerous and singing so lustily that it is impossible to hear or distinguish the songrs of any of the smaller birds.

Song.-Delivered in parts with intermissien of a few secomils between, from morning until night; a short varied warble: calle a petulant mew.

Nest.-I basket wowen of strips of bark and fibres, and often with pioces of newspalper worked in. linesi with fine grass: exgs white with a few blackish-brown specks on the large end $(.85 \times .55)$.

Range.- $\mathrm{L}$. S, east of the Rorkins, breeting from the finlf to Labrador and Manitoba: winters in Central America.

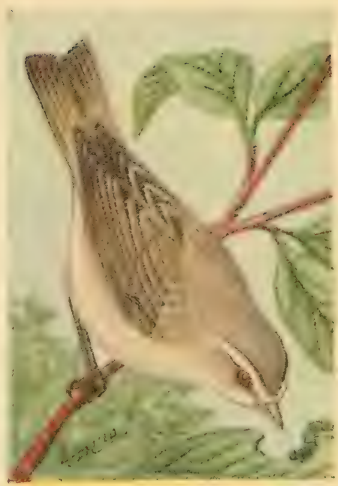

135 


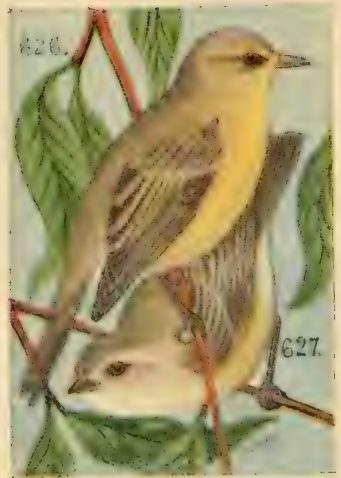

136

\section{PHILADELPHIA VIREO.}

626 . Tirmsylin philadelphicu. 5 inches.

This is ene of the least common of the eastern Tireos, although it is more commom than most people know: its song is not distinctive and it keeps high up in trees, so it is not monally motioel. Their nests are swang from branches at ligh altitules and are seldom found.

\section{WARBLING VIREว.}

627. Tireosylea gilva. 5 inches.

Alove dive-grens are wh graper but with no black borter. These are among the most common of the Vircos and may be fomm even in the hearts of large cities. swinging their pretty little nests high up in shatde trees. Their sime is atter the strle of that of the Purple Finch. rery dilferent from that of the Red-ere. The ergs are white with a fow hrown specks on the larwe ent. These birds breed throughout the $\mathrm{L}$. S. and southern Canada. 


\section{YELLOW-THROATED VIREO.}

6.2s. Laniviren farifirms. $5 ?$ inches.

Lpper parts sreenish: throat, breast and line orer eye yellow: two prominent whitish wing bars.

I' hambarine I irea found in lecalities such as are frepuented by the Red-eyed species. Nowhere do they appear to be as abumblant as that speedes, howerer: they are mone abmolant than many supposes lut the diflendty of chealy secing the yellow breant when they are feeting in the tree tops. combined with the similaty of their songs, nonally calused them to be passed by without inspection.

Song. - Similar to that of the Red-ere. hut louter and more nasal, less varied and not. uttereed as often.

Nest.- I pensile structure of strips of bark, grasises. p.te., with the outside often ormamented with lichens: three to five exgrs with a creamy or rosy-white tint. specked. more profunely than those of the Red-eye, with reddish brown $(.82 \times .60)$.

Range.- Wastern L. S., hreeding from the Gulf to sonthern Canadal winters in C'entral America.

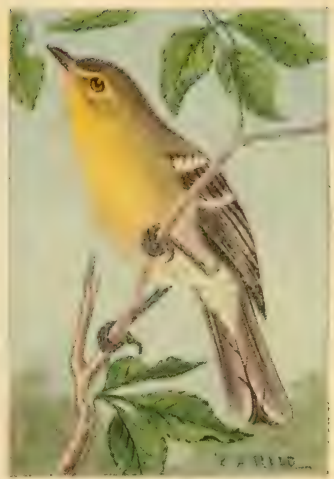

137 


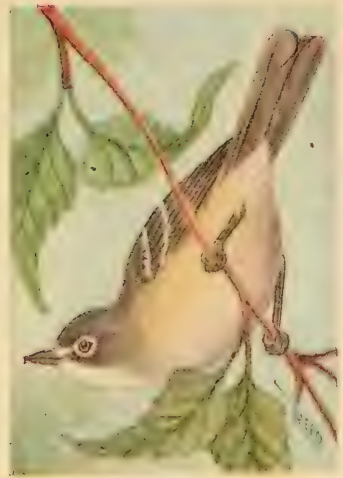

138

\section{BLUE-HEADED VIREO.}

629. Lunitireo soliturius. $5:_{4}$ inches.

Crown and sides of head bluish slate: lores, eye-ring and unlerparts white: back and flanks greenish yellow; two whitisli wing bars.

This species, to my ere is the prettiest of the Vireos, all the colors being in just the right proportion and blending and harmonizing perfectly. They are solitary, in that they are usually foumd in deep wooks glens or ravines, and seldom is more than one pair found in a single woods.

Song.-Cimilar to that of the Yellow-throated Vireo but longer and more varied.

Nest.-A handsome. finely woven hasket, with the outsiale corered with spider webs and often with lichens: egres pale crealmy white with chestnut specks.

Range.-Eastern $\mathrm{X}$. A.. breeding from the Gulf to New brunswick and IIanitoba; winters south of the United States.

Sub-species. - (i2?e. Mountain Solitary Tiren (alticola), head darker and back less greenish; Alleghanies from North carolina to Georgial. 


\section{BLACK-CAPPED VIREO.}

630. Vireo atricapillus. $4^{1} \leqslant$ inches.

Male, with crown and sides of lead glossy black, lores and eye-ring white: female, duller colored.

This strange and comparatively rare lireo frequents brushword on the prairies of Kansals. Indian Territory and central and western Texas. Their habits in all resperts resemble those of the more commom Virees or Greenlets an they are otherwise callerl.

Notes. - imilar to those of the White-ered Vireo.

Nest.- Suspended as usual from forked branches at low elevations: made of fibres and bark strips closely woren togethe: with spider wehs. The four eggs are pure white, unmarked $(.70 \times .52)$.

Range.-Breeds from central and western Texas north to -outhern Kansils: winters in Mexicu.

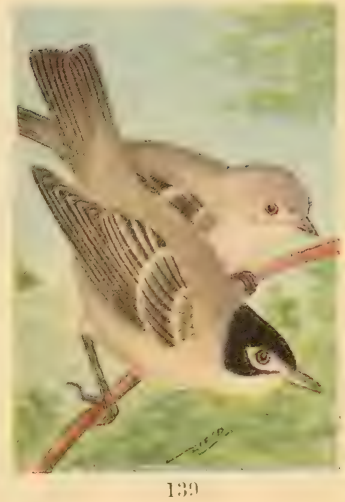




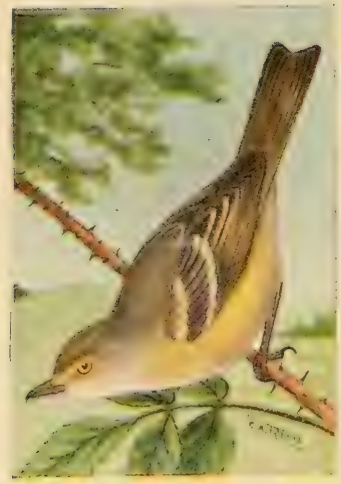

140
WHITE-EYED VIREO.

631. Tireo grisews. 5 inches.

This species show's a partiality for low, swampy places, covered with briars or tangled thickets of blackberry vines. Their habits are entirely dilferent from any of the preceding lireos. They do not seem to sing as they eat, but feed in silence, then, the task ended, momint to the tops of the brush and indulge in an endless variety of calls and whistles.

Song.-I great variety of dear whistles and squeaky notes.

Nesi.-A bulky structure of strips of bark, leaves, yaper, ete., either placed in the branches or partially suspended in a fork; eggs white with minute brown specks $(.75 \times .55)$.

Range.-Eastern United States, breeding from the Gulf to Massachusetts and Manitoba; winters in Mexico.

Sub-species.-ijlal. Key West Vireo (maynardi), southern Floridat, (5:311). Bermuda White-ered Vireo (bermudianus). resident in the Bermudas. (i3le. Simall White-yed Vireo (micrus); southeastern Texas. 


\section{BLACK AND WHITE WARBLER.}

636. Iniotilta varia. $5 \frac{1}{1} \pm$ inches.

Male, heavily streaked with black below; female, with only a few streaks on the sides.

These 11 arbless are usually known as black and White creepers because of their habit of ereeping along the limber and branches of trees. Ther ane abundant in northern (nited states, being found in open woorls, swamp and witen in parlis, gleaning inserts and gruls from erevices in the bark.

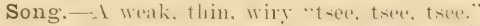

Nest.-(l) grassen and stlips of hark on the grommel at the fort of at stump or tree trunk or leside a rock: ther lay four or fire exgs. White with a wreath of re:l-

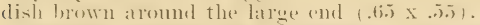

Range.-Eastern \. ... hreeding from Virginia aml

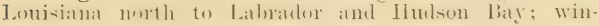
ters in northern South America.

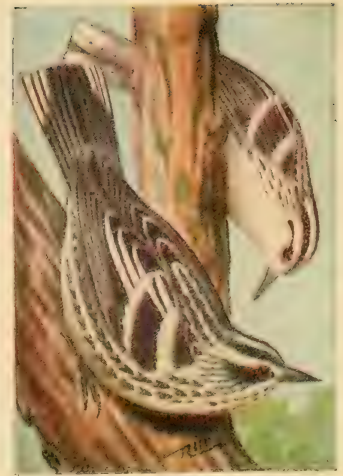

141 


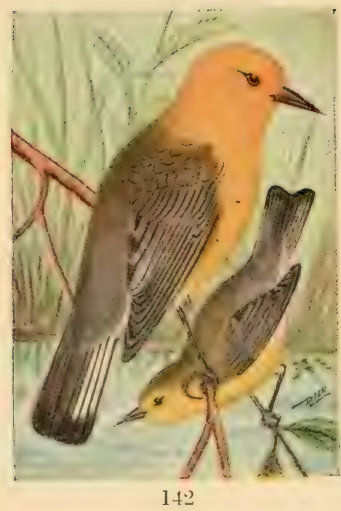

\section{PROTHONOTARY WARBLER.}

637. Protonotaria citrea. $5 \frac{1 / 4}{4}$ inches.

Whole head and underparts intense yellow, almost orange on the head of the male; tail with white spots near the tip; female, duller.

A common species in the interior, found in bushy swamps and the willows around the borders of pools and lakes; they are found in the latter localities with Tree Swallows and often Chickatees all nesting in holes in hollow stubs along the bank, they being one of the few members of this family to make use of such locations for their nests.

Song.-A luml, ringing "tweet. tweet. tweet."

Nest.-In hollow stubs near or over water, the eavity of the stump being partially filled with moss, leaves and grasses hollowed on the top to receive the four to six creamy-white eggs which are heavily spotted over the entire surface with redelish brown $(.72 \times .55)$.

Range.-Fastern L'. S.. breeding from the (iulf north to Virginia, Illinois and Minnesota; winters in ('entral America. 


\section{SWAINSON WARBLER.}

638. Helinaia suainsonii. 5 inches.

Epper parts hownish: underparts whitish; a white superciliary stripe and a brown stripe through the eye.

some of the habits of this species are similar to those of the last but they are eren more anuatio: they like swamps or stagnant pools thickly grown with rushes and tameler underbrush: unless eognizant of their habits, one wonld nerer look for a Warbler in the places frecuented by these birds in company with Least liatterns and Marsh Wrens. Cntil within a few years these were regarded as rare birds but are now found to be not unemmmon in certain of the South Atlantic states. notably Georgia.

Song.-A series of descending, loud, clear whistles with a rentriloquial effect.

Nest.- puite large structures consisting mostly of leaves with strips of bark, roots and pine needles. The four or five eggs are plain white, being the only egrgs of American Warblers that are ummarked.

Range.-Coutheastern L. S. from Georgia to Louisiana and north to North Carolina and Missouri.

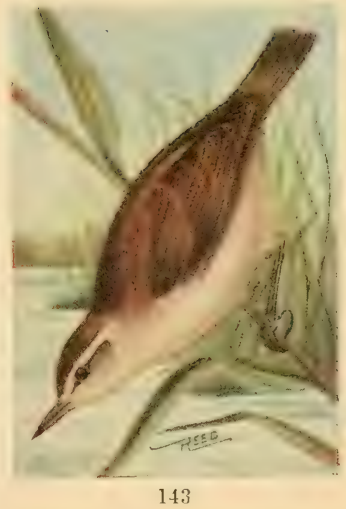




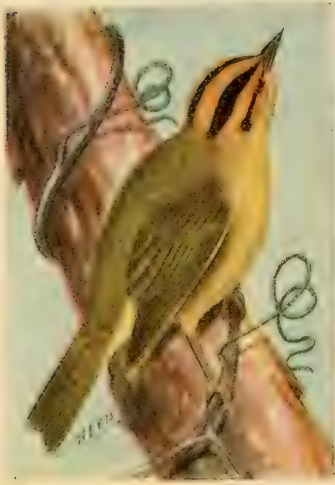

144

\section{WORM-EATING WARBLER.}

(63). Ifrlmitheres rermiroms. 5i.; incles.

Crown butly with two black stripes: batek, wings and tail olive green with no white natring-: lectow bufly white.

these birds are very unsuspicions and (alsy to approach: they spend the ereater portion of their time on or mear the gromml: they are very fomed of spiders and find quantities lo werturning bits of bark and leates. They alor shan part of their living trom the moler side of the folliage much as de the Vireers. Ther

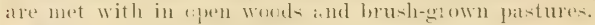

Song.-A weak, rapid chipping.

Nest.- (n) the groumd in depressions under logrs. stomen or luslues: of leaves amel errass. lined with fine

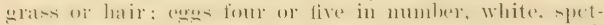
ted wincipally aroumd the large end with brownish (.70 $\mathrm{x}$...5.).

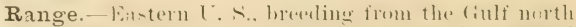
to (immecticut, (Hhio and lowas: winters in central America. 


\section{BACHIMAN WARBLER.}

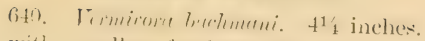

Male, with a yellow forehead, shouliters and nomberparts; black cap and breast pateh; female, duller and with less black.

This speceies was first diseovered hy Dr. John Bathman near Charleston, S. C.

Song. - In insigniticant warble or twitter, similar to the song of the Parula.

Nest.-In liw hushes or briers, one to three fect above gromul. Mate of tine grasses and leaf skeletons, lined with black filmes. Foumel breeting hy Wilmamm in Misonui, by Embory in Kentucky and by Wayne in

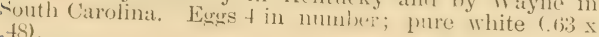
.48).

Range.-Foutheastern T. S., north to Nenth Carolina and west to Missouri. Rare and lowal in distribution.

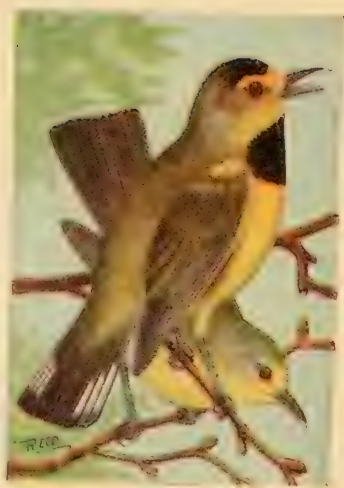

14.5 


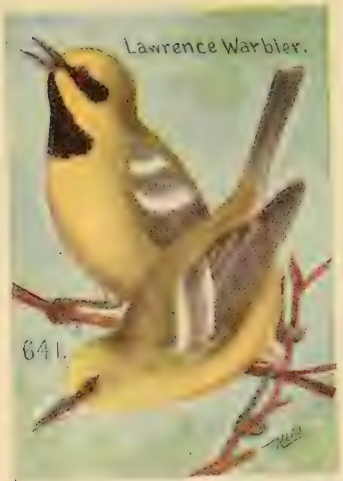

140
BLUE-WINGED WARBLER.

641. Termizora pinus. $4^{34} 4$ inches.

Crown and umderparts yellow: a narrow black line throngh the eyen: two homel whitish wing bars.

A common hirl of the southeasterm states and north

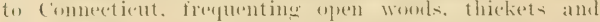

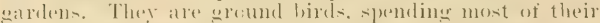
tine on the enomel or in low bushes which they clean of the insects which are destructive.

Song.- I lemel. rapiul dhirruj, similar to that of the

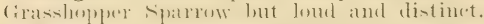

Nest.- fli leares and strips of bark, lined with fine

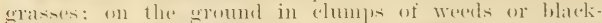
frerry vines: enge white, sporingly spotted aroumd the large end with rufous $(.65 \times .50)$.

Range.-bit-tern l'. S.. breeding north to sonthem connectient and Wisconsin: winters in the tropies.

Hybrids.- Latwerese Warbler. which is a hybrid hetween this -peredes and the next: it has the general

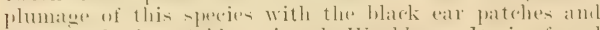
throat of the ciolden-winged Warbler. lt is fommel chielly in sonthwentorn (ommedicut and New York. 


\section{GOLDEN-WINGED WARBLER.}

612. Termicora chirysoptera. 5 inches.

Crown and two large wing hars yellow; throat and ear patches black; rest of plumage gray and white; female with less black.

The distribution of this heautiful Warbler is abont the same as that of the last, with which it stems to have many habits in common. It seems in prefer low ridge's and side hills covered with small bushers.

Song. - A buzzing "zweer-ze-ze."

Nest.-Of leaves, rootlets, strips of bark and grass; located on the ground among climnss of weeds, usually in moist places; eggs white with brown specks $(.62 \mathrm{x}$ $.48)$.

Range.-Eastern U. S., breeding north to Commecticut anil Michigan; winters in Central Ameriea.

Hybrid.-Brewster Warhler is a hylorid between this species and the last. It resembles the Golden-winued Warbler without the hlack, but with a yellow patch on the breast and the black lina of the Blue-wing througi the eye.

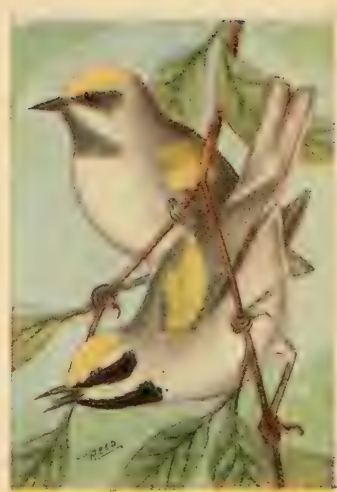

147 


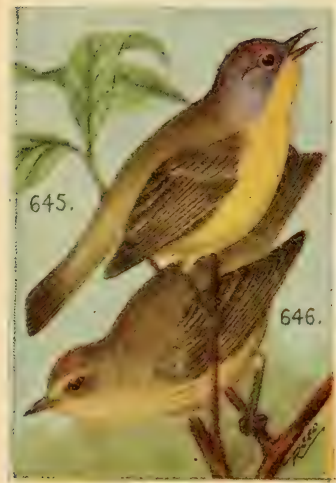

148

\section{NASHVILLE WARBLER.}

(45). Termivora rubricapilla. $43 / 4$ inches.

Male with a brown erown patch: female duller colored and with no crown patch. Dry side hills covered with young trees are favorite resorts for the Warblers. They conceal their nests on the ground under tufts of alead grass or wrerlanging stomes. They are often rather shy and haril to sight. lout you can nistally hear their song. " lazy sounding "ker-chip-chip-chip-cherr-wee-e-e" ending in a short trill. These birds breed in the northern half of the L. S. and suthern c'anada, wintering in central America. A sub-spectes is found on the Pacific coast.

\section{ORANGE-CROWNED WARBLER.}

646. Termivora celata. 5 inches.

This species is falirly eommon in the Mississippi Valley lout is rare in New England. Its habits are much like those of the last speries and it is often mistaken for that hird. These hirds breed only north of the L. S. amel winter in Mexico. A sub-sjecies, the Lutescent Warblers, nests from California to Mlaskil. 


\section{TENNESSEE WARBLER.}

647. Termicora peregrimu. is inches.

Male, with a gray head and greenish back; female, with the top of the head the same color as the back.

A dull-colored bird that. with the exception of the bill, bears a strong resemblance to some of the Vireos. Like many others of our birds, this one las received an inappropriate name. because the first specimen was shot on the banks of the C'mmberland River. While the hird is no more abundant in Temnessee than in other states during migration.

Song.-I simple ditty similar to that of the chipping Sparrow.

Nest.-Fither on the crouml or at low elevations in hushes: of grasses and fibres lined with hair: egges white. sparsely specked with reddish brown $(.62 \times 2.45)$.

Range.-liastem $\mathrm{N}$. A. loreeding from the northern parts of the northern tier of states northward to the imit of trees; winters in central and south Amerion.

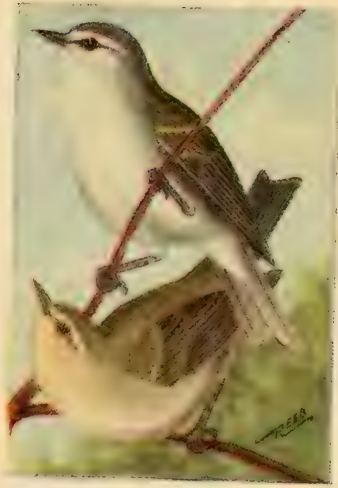




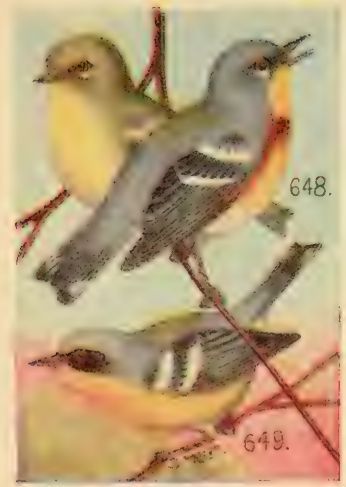

1.511

\section{PARULA.WARBLER.}

6its. Compsolhtypis ancrioma. tin inches.

In the summer P'arulas are foumd in wet swamps where the groumd is covered with a carpeting of moss which only patially keeps your feet from the water below: the dead trees are enered with a growth of long. cheoping moss: the ends of this moss are turned up and formed into a neat crarlle within which the eggs are laid.

Song.-A little lisping trill.

Bange.-lireceds in the southerm half of the $\mathcal{C}$.. . The Northern Parulat (usieal). No. (itsal, loreeds in the northern half of the L. S. and sonthern Camalas: it is brighter enlores tham the southern form. Both varieties winter from the (inlf states solthward.

\section{SENNETT WARBLER.}

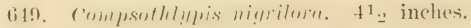

I smaller -imilar bird from southern Texas. Sote the black ear patches and lack of black on breast. 


\section{CAPE MAY WARBLER.}

650. Dendroica tigrina. 5 inches.

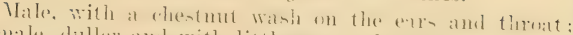
female. dallere and with litte or no chestume

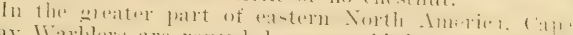
May liambers are regarded as rare birds: they appear to migrate in complatet bolies. not spreating ant onet

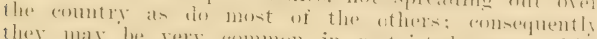
they may ine rery ammom in restricted alreas while lacking entirely in others. I have never met with but

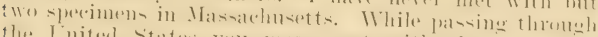
the [nited states you may meet with them in cren woosls, parke or in shate trees alomg the st reets of eit ies. times.

Song.-1 thin. hiwh-pitched whistle reverated sireral

Nest.-Of small cerlar twigs lined with horse hatir, placeri within a ferr feet of the crommel in small cedar trees: coges white spotted with brown t.(is $x$.it)

Range.-Eastern X. L., hreeding in eastern ('anal) and. rarrely. northern Xew England; winters somth if

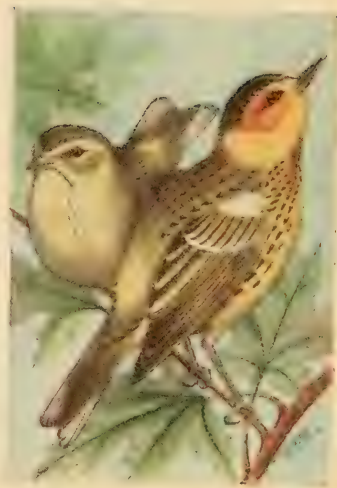

151 


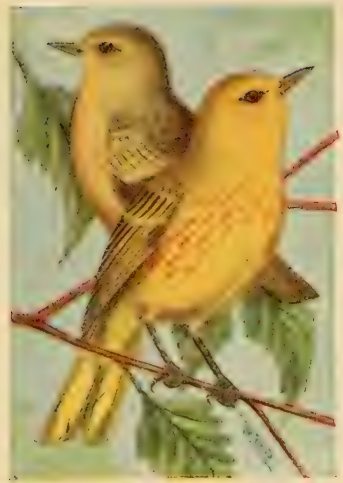

$15 \div 2$

\section{YELLOW WARBLER.}

\section{Dendroica estiva. 5 inches.}

Tale. with rluestmut streakin on ther siles: female, duller and without the streaks.

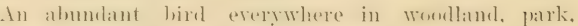

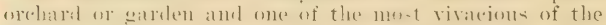

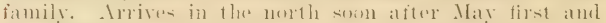

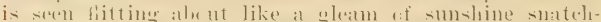
ing insere from the folliage or darting after them in

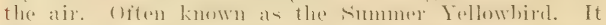
frequently nests in waten or orehard trees, where it is a most weleome tenant.

Song.-1 - harp, vigorous "che-wee, che-wee, che-wer." Nest.-I beantiful amd comparet structure of renetable or plant fibres firmly guilted together, and filstened to upright forks of hushes or trees at low elevattion-. Willows alomg erecks, ponds or rivers are favorite resorts.

Range.-N. A. loreeding from the Gulf to Ialbrator and Alaskal winters in central Americal. 
BLACK-THROATED PLUE WARBLER.

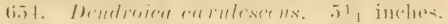

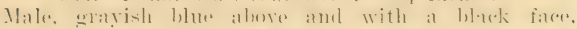

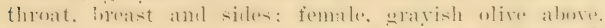

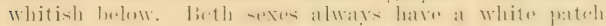
or speck at the hase of the primaries.

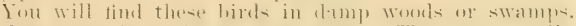

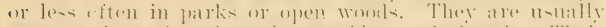

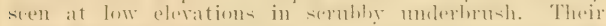

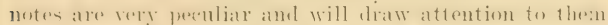
anywhere.

Song.--1 ine wating whintle with a sharply ricing inflection. "zee-zee-zwee."

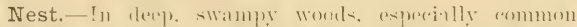
in lanwe of grape vine bark amel roulets lined with

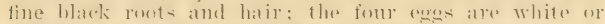
lutry white with reshlish-brown spots and blotelese.

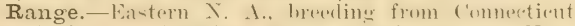
(sparingly, and Mirhigan nerth to Labrator and IInd-

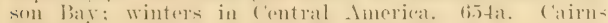

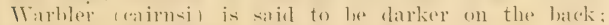
found in the southern Alleghanies.

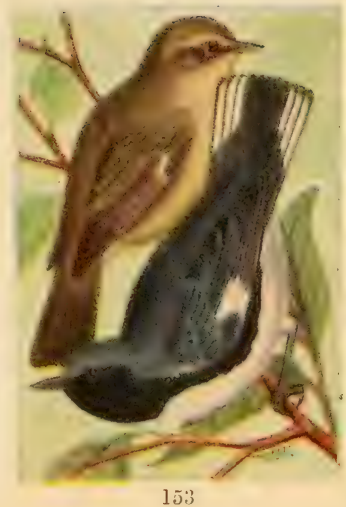




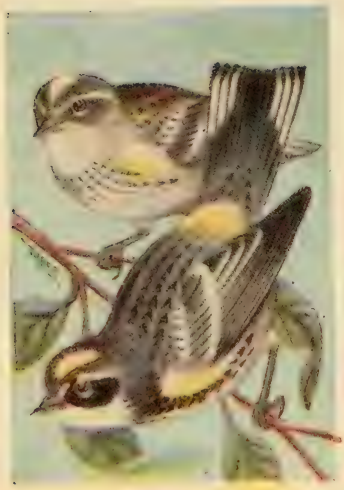

154

\section{MYRTLE WARBLER.}

655. Dendroica coronate. $5 \frac{1}{1 / 2}$ inches.

Vellow pafches on crown. sides and rump: outer tail feathere with large white spots: female duller and browner.

1)uring migrations these pretty hirds are very ahumdant in the Cniterl states. They usmally traved in large fiockis an that a small piece of woodlind is litarally thosked with them when they panse in the tlight

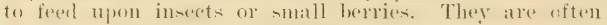
known as Vellow-rumped Warblers.

Song.-1 rear. broken trill or warble.

Nest.- - sllally in coniferous trees, though sometimes in others. and it low elerations: of plant fibres anl grasues: the four or fire egos are white. spotterl aml bloteled with reddish hrow $1.70 \mathrm{x}$.it).

Range.--Eastern X. A. breeding from northern Xיw Englanil and Minnerotil northward; winters south of the l. . . 


\section{IMAGNOLIA WARBLER.}

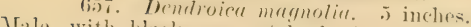
math black ealr pateh. back. amel necklace: fe. mile. with the hlack replaced with grayish: hoth sexes have a vellow rump and white spots midway of the tail feathers.

One of the prettiest of the Wirblers and ane of the Ieast timid. I have often had one ar more of these biris follow me the whole length of a piece of womls apparently out of euriosity. coming shern of the nearest trige within arms reach of me. Birch weols are their favorites during migrations. although at fell of them will be fomel almost answhere.

Song.-1 shert rapilly uttered warble.

Nest.-F sually in coniferoms trees. far mat on the longer loranches. where ther are often dilinenlt to wat at: of rootlets lined with fine black reotlets and hatir: four wr five white egge with small spots of ehestmut around the large end $(.60 \times .48)$.

Range.-Falstern N. A. breeding from Massachusott. and Jichigan northwar!: winters south of the $[$.

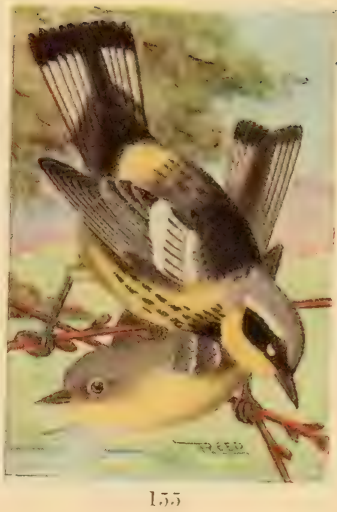




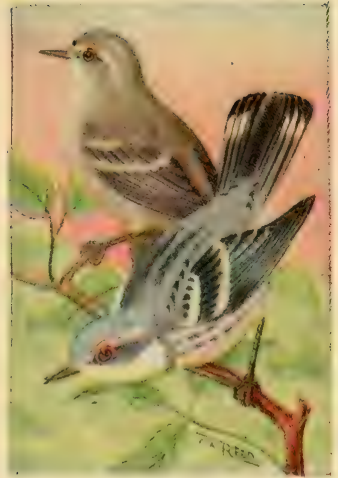

156
CERULEAN WARBLER.

658. Lendroicu catrulea. 5 inches.

Above grayish blue with black streaks, below white with a bluish breast band and streaks on the sides; female washed with greenish above and rellowish below: both have white patches near the ends of the tail feathers.

These dainty little Warlulers are not abumbant anywhere, but seem to be most so in the central states. they are birds of the tree tops. rately coming down so that they call be distinctly seen They mas be more common than supposed, for so small a body at such heights ean readily be orerlooked.

Song.-A little watbling trill, "zer-zee-ze-ereep."

Nest.-In the higher onter branches of large trees usually in deep woods: compactly male of dry grasses and colswels, adorned with a few lichens: egow white specked at the large end with brownish (.6.) x .50)).

Range.-Interior portions of the $\mathrm{C}$. S., lreeding north to Michigan and Mimmesota; east to Western New lork and. rarely, sonthern New England; winters in northern South America. 


\section{CHESTNUT-SIDED WARBLER.}

65!). Dendroica pensylianira. of inches.

Yellow crown, black line through eye and on side of throat, and hroad chestmut stripe on sides: female, paler and with less chestnut: roung greenish yellow above and with no chestnut.

Nearly every swamp or bush-eovered pasture within their rainge slielters one or more pairs of these IFarblers. While they sometimes feed in the tree tops. they are hirds of the lower foliage and are usually seen in
low bushes.

Song.-Cimilar to that of the Yellow Marluler but more choppy.

Nest.- In low bushes or weeds, and often in swert. fern or briars: similar to that of the Vollow IVarblex lout coarser. being male more with grasomes than with filores, situated in upright forks or attacherl to several weed stalks: egges white, sperked around the larese end with reellish brown (.68 $x$.50).

Range.-Fastern N. A., breeding from New Jersey and (Hhin north to Manitoba and New Brunswick: winters south of U. S

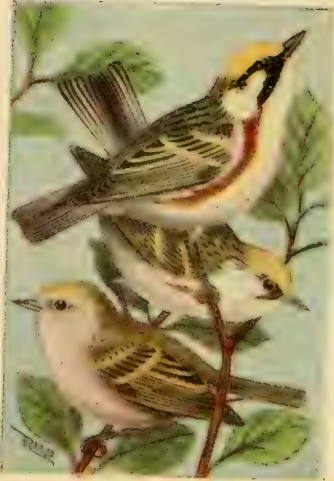

157 


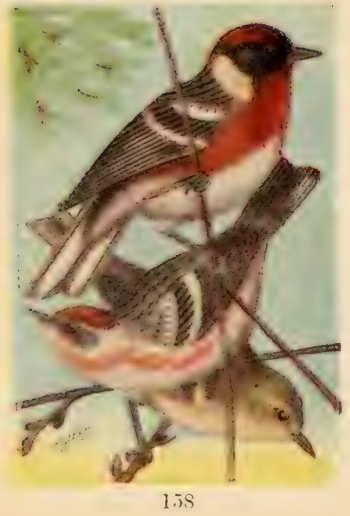

\section{BAY-BREASTED WARBLER.}

660). Dembrica castanca. 512.2 inches.

Male, with crown, throat and sides rich chestunt: fomale, paler: roung and adults in winter, grreenish above, streaked with black and with a trace of chestnut on the flanks.

These Warblers are only locally abundant during micrations. While in eastern New England they are rare, Ther ale active insect hunters, darting rajidly about the trese tops or, less often. in hrush: their halits most nearly renemble those of the chestmut-sided IVirlbler.

Song.-A low, liquid warble.

Nest.-At low elevations in trees in swamp! wools; compact. (mup-shaped structures made of tine shreds of lark, rootlets and gratso: egras bluish white, tinely specked aroment the lange end with redelish brown $1.70 \mathrm{x}$ $.50)$.

Range.-Eastern X. A.. breeling from the northern exloe of the L. . nortliwad: winters soutl of the $L$. s. 


\section{BLACKBURNIAN WARBLER.}

Thale, black above with large white batch on wing, and hases of outer tail featlers white; thruat amil breast intense or:mge; female, duller and with the orange replaced hy dull yellow.

Withunt exception, this is the most exyuisite of the whole family; it is the most eagerly soment birl by bird lovers, in the spring. Some years they are very abmulant, while others few are seen, their routes if migration evidently rarying. They arrive about the time that apple trest are in blom, and are frequently reen among the hlosions, dashing after inserts.

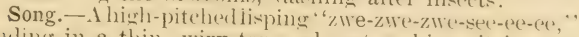
rneling in a thin, wiry tone, almost a hiss; it is vory distimet from the song of any other biril.

Nest.-In coniferonis trees at any height from the Erounl; of shrerls of hark, fine cenlar twigr, rootlets, etc.; exgs greenish white blotcherl with brown.

Range.- Eastern N. A., breeding from Massachusetts (rarely) and IIinnesota northward; winters in Central America.

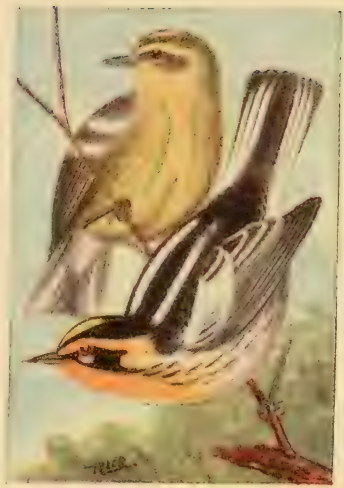

$1.5,4$ 


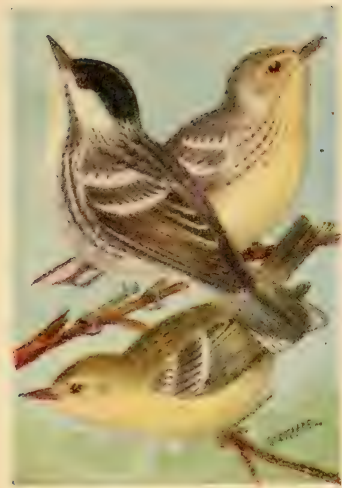

160

\section{BLACK-POLL WARBLER.}

661. Dendroica striata. $5^{1 / 2}$ inches.

Whole crown black: female, witleut black cap, qreeni-h gray alowe streaked with black; youmg paler than the female.

These hirds are one of the latest of the miorants to arrive, reaching northern Conted states about the last of Mas, lut coming in such numbers that they are found evervwhere. While their plumage somewhit resembles that of the lBlack and White Watrbler. their habits are entirely different.

song.-I high-pitched, hissing whistle similar to that of the black and White Warbler but uttered more deliberately and with an instant ss patnee between each note.

Nest.- It luw alevations in thick coniforons trees: mate of slemerer twigs. rootlets and lichens. lined with hair or feathers: ergers whitish, thickly spotterl with brown $(.75 \times .52)$.

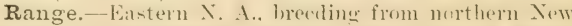
England. Mimmesotal and Wyoming north to the Aretio rewins: winters south of the Lnited states. 


\section{YELLOW-THROATED WARBLER.}

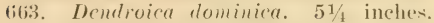

Throat, breast and line from eye to bill rellow.

This species has habits very similar to those of the lilack and White (reepere, being often seen creeping around the trunks or oser the hranches of trees with ahost as much facility as the Nuthatehes. They are sinuthern lirels and are only rarely or aceidentally formd in the northern half of the $[$. S... and they are one of the few members of the family lhat winter in the southern parts of our country.

Song.- - loud and similar to that of the Indigo Bunting, but shorter.

Nest.-['slally high up in pines and often enneraled in tufts of moss; male of tine twigs and strijes of lark. leedel together with cohwels and spanish noms: egress erenish white. spotted with varions slatdes of hrown.

Range.-Goutheatetern [. S.. breeding north to Vir-

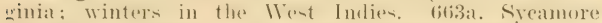
Warbler (albinorat is like the vellow-throated. but is white before the eve: found in the Misissippi Valley north to Illinois and [owa: winters in Mexico.

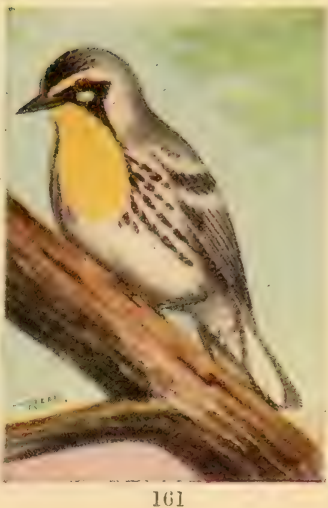




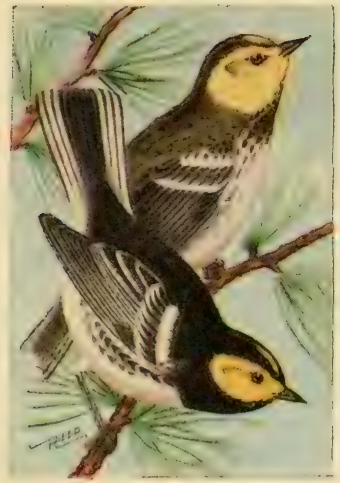

162

\section{GOLDEN-CHEEKED WARBLER.}

666. Dendroica ehrysoparia. $4 \frac{3}{4}$ inches.

In some plumages these hirds may be confused with the Black-throated Green. Notice that the adult male has a short median line of yellow on the crown, otherwise the top of head and entire back are intense black. Foung birds, which bear the elnsest resemblance to the next species, can be distinguished because their underparts are white, those of the Black-throated Green being tinged with yellow.

These rare ITarblers have a very restricted distribution, but are said to be not uneommon within their range. Notes. - Song with the usual Warbler quality, but entirely distinctive: "sweah-swealh-swee-e-e."

Nest.-Of strips of bark, usually located in juniper trees six to twenty feet above ground. Eggs white, splashed about the large end with reddish brown $(.65 \times .50)$.

Range.-C'entral Texas southward into Mexico. 


\section{BLACK-THROATED GREEN WARBLER.}

667. Dendroica virens. 5 inches.

Throat black; two wing bars and outer tail feathers white; female with little black on the throat.

A common bird in pine groves in northern Initerl States, or during migrations in birch woods. I have formd theme most abundant on side hills covered with low-growth pines. They seeni to be very nerrous and are ireatly excited if you appear near their nests. They often have the habit of building several nests, whether with the deliberate intent to deceive or whether because the first was not satisfactory as to lucation is not known.

Song.-Entirely different from that of any other birct; a rather harsh "zee" repeated six times, with the fourth and fifth syllables lower.

Nest.- (if rootlets and fine grasses, lined with hair; placed high up in pine trees; eggs white with fine lowwn specks around the large end $(.60 \times .50)$.

Range.-Eastern Forth America, breerling from southern New England and Illinois north to Nora sontia and Hudson Bay; winters in Central America.

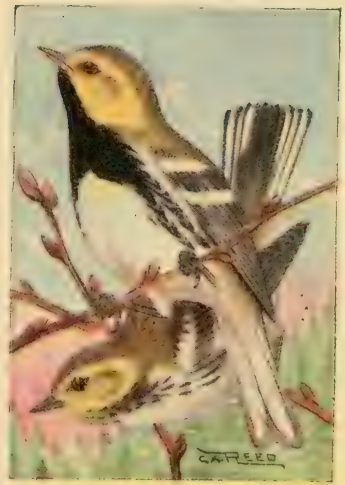

163 


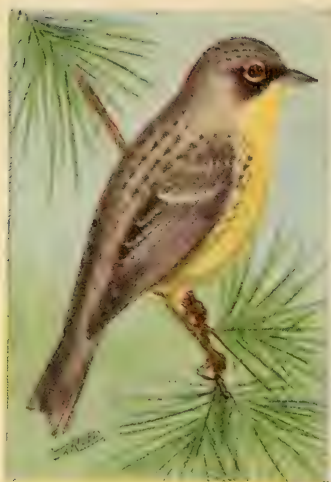

164

\section{KIRTLAND WARBLER.}

670. Demlroica livitlanti. 51/., inches.

Alove bluish gray streaked with black; underparts pale rellow streaked on the side with black.

This is one of the rarest of American Warblers. and until 1901:3 but little wats known of their habits or yatage; in that reat they were discovereet nesting in ()sendal (inuntr, Sichigan. They were foumd near the banks uf a river in Jack pines, building on the ground and remaining in the underbrush near it.

Song.-Loml and clear and sail to resemble that of the Maryland Yellow-throat.

Nest.- In depresions in the ground at the font of pine trees and probalily also under bushes: made of strips of bark and regetable fibres: enges white. Wreathed about the latge end with brown $(. \overline{1} \times \mathrm{x} .5(i)$.

Range.-breeds in Michigan and migrates southeast through (Ohio, Misisuri, Temnesisede, Virginia, the Carolinas and Florida to the Bahamas. 


\section{PINE WARBLER.}

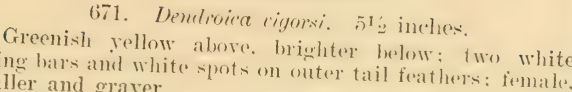
duller and grayer.

Found only in tracts of enniferems trease except durine nigrations. When ther are often in tores. except during kinds of Warblers ine often in cempany with othere serub pines and are often like dry hillsides corered with tips. They are rathen quite abmelant in such loeali-

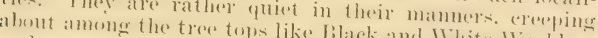

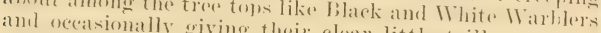
Song.- Veirot giving their clear little trill.

but easily distineruishablet of the (hipping sparew, Nest.-A small, compact a long. "lear trill.

lined with hair: places in theture of blatek rootlats pines. where it is reles in the extreme tops of seruh spered with redelish doment to sere them: egges white

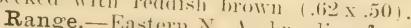
to southern Canada; winter ineeding from the Gulf north

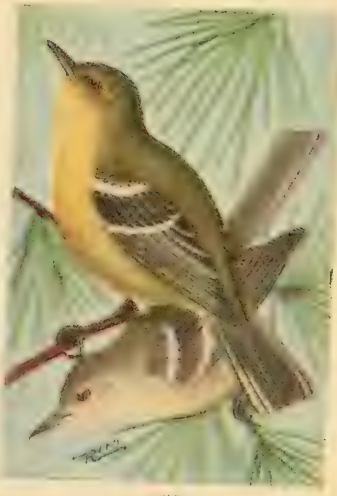

$16 j$ 


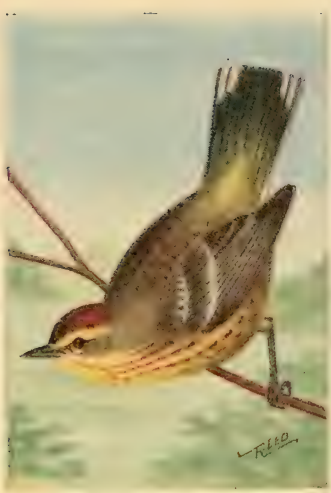

166

\section{PALIV WARBLER.}

6iz. Dendroirat palmarum. $5 \frac{1 / 4}{4}$ inches.

No wing hars. but white spots on the outer tail feather's: crown, cheeks and streaks on the sides ehestnut.

During migrations you will find these Warblers along roalsiles. in open wook and scrubby pastures. They are of a very nervous temperament and, when at rest or when walking, are continnally flirting their tail, a habit which mose of the IVarblers. except the Water-thrush, seem to have. They are one of the earliest of the family. to appear in the spring, reathing northern Lnited States in April.

Song.-A short trill: an melinary Warbler chirp.

Nest.- un the ground under slirubs, or sunken in mosi: made of tine grakses. lark and moss: the four eggs are creamy white with redulish-hrown spots.

Range.-Interior of X. A.. hreeding in the interior of British Ameriea: winters in sonthern [. S. (60)a. Yellow Palm Warbler (hypochryea) is brighter yellow below: it is found in eastern $\mathrm{X}$. A. breeding north of Nova Scotia; winters along the Gulf. 


\section{PRAIRIE WARBLER.}

thove 67. Dendroict discolor. $4 \%$ inches. belowe greenish with chestmut spots on the back; elow vellow with black markings: female paler.

These are very locally distributed birds and will often be found breeding abundantly in a small pateh of brushcovered pasture, while many others apparently just as well suited for their purposes will be shmmed by them. They are very active, flitting rapilly from one bush to another, the male occasionally mouriting to a bush top to hurriedly deliver his song, then diving out of sight below the foliage.

Song.-An energetic, rather harsh "zee-zee-zee-ee" on an ascending scale.

Nest.-A neat cup of grasses and regetable filres, lined with black rootlets or horsehair: located in low shrubs or bushes from one to two feet above ground; egges whitish with blackish-brown specks about the large end $(.65 \times .48)$.

Range.-Eastern U. S.. breeding from the fiulf to Massachusetts and southern Michigan; winters in the West Indies.

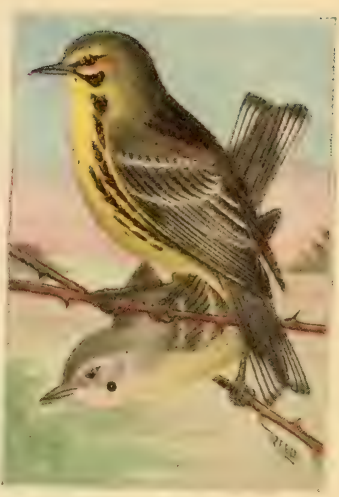




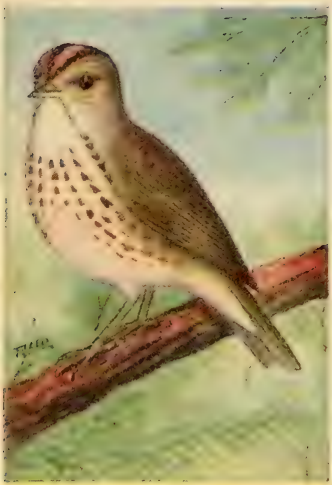

168

\section{OVEN-BIRD.}

674. Sciurts aurocapillus. 6 inches.

crown orange brown bordered by black: no white in wings or tail.

This bird is found in open woods, where it builds its arched nest on the ground amomg the leaves or pine needles. It is the peculiar oren-like eonstruction of their nests that gives them their name. They are essentially ground birds, only mounting to the lower branches of trees to sing or when seolding an intruder.

Song.-A peenliar areending song resembling the word teacher. repeated five or six times and gathering strength and volume with each srllable: call, a sharp elip.

Nest.- ()f leaves, strips of bark and grass arehed orer the top so as to leave a rery small upening: placed on the groumd in wools: four to -ix white exgos spetted with reddish brown $(.78 \times .58)$.

Range.-Eastern N. A. hreeding in the northern treer of the I. S. and north to Labrador: winters chietly south of U.S. 


\section{WATER-THRUSH.}

675. Seiurus nureboracensis. "inches.

This -peres always has a yellowish tinge to the underparts and the stripes beneath are narrow, hut prominent. These llarblers are foumd in tangled underlorush near water. They have a habit of continnally flirting their tails, thits giving them the lueal name of ilater-11 atgtail. Their call is a sharp metalie "chink": their somg a lend,

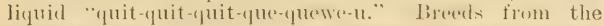
northern edge of the L. S. northwards; winters south of U. S.

\section{LOUISIANA WATER-THRUSH.}

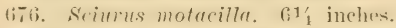

Larener. glayer alowe and whiter below than the preceding: stripes fewer and broater. This is a more sontherm speecien and loreeds from the (iulf to comnectient and sontlern Mimesota. Its notes are wiled and ringing. like there of the last. They build their nests under the roots of trees or under the edgess of orerhanging bankis. The egges are creany white, boldly blotehed with brown.

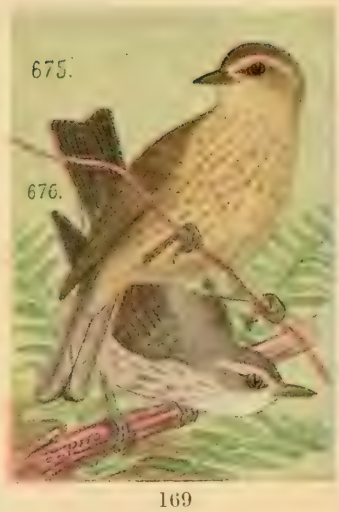




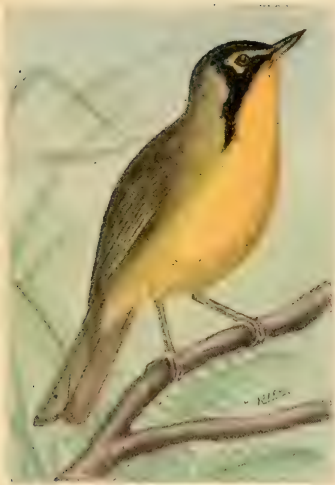

170
KENTUCKY WARBLER.

677. Opororni: formoser. $5^{1 / 2}$ inches.

Crown and ear eoverts black, underparts and line over eye yellow; no white in the plumage.

These birds are found in about such localities as are frequented by Ovenbirds, but with a preference for woods which are low and damp. They are locally common in some of the southern and central states. They are active gleaners of the underbrush, keeping well within the depths of tangled thickets. Like the IIaryland Yellow-throat, which has similar habits to those of this bird, they are quite inquisitive and frequentiy come close to you to investigate or to scold.

Song.-A loud, musical. Wren-like warble.

Nest. - A bulky structure of leaves, hark and grasses, lined with black rootlets or horsehair; placed on the gromel in bunches of weeds or at the foot of a small fuslı; the four or five egges are quite heavily speckled, chiefly at the large end, with reddish brown.

Range.-Eastern L. S.. breeding from the (rulf north to New York and southern Michigan; winters in northern South America. 


\section{CONNECTICUT WARBLER.}

578. Oporornis ugitis. 5$)^{1}$ inches.

Male with a bluish slate-(o)lored head: ere ring white and completely encireling the eve; female with a safroncolored head.

In the Lnited States we find this Warbler only in spring and fall migrations. They appear to be nuch more rare in the spring than in the fall; while I have seen perhaps a humdred in the fall I have never seen but one in spring. Ther freguent wild tamgled thickets. such as you often find ifaryland Vellow-throats in. As they do mont of their feeding upon the gromel and remain in the depths of the thickets, they are racely seen umleson attention is drawn to them.

Song.- Somewhat like that of the Marrland Yellowthroat: call, a sharp, metallic "peenk."

Nest. - In thickets or clumps of hriars, either on the ground or just above it; male of strips of bark and skeletoms of leares. lined with hair: exgs whitish sparingly specked at the large end with brown $(.75 \times .56)$.

Range.-Eastern X. A., breeding north of the L. S.; winters in northern south America.

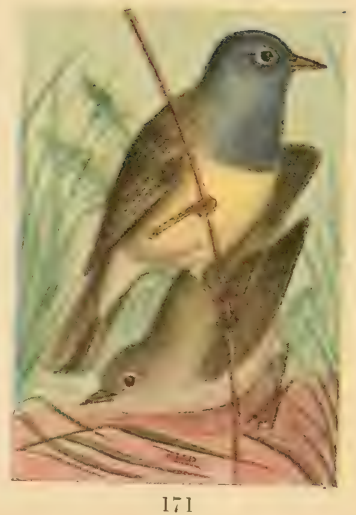




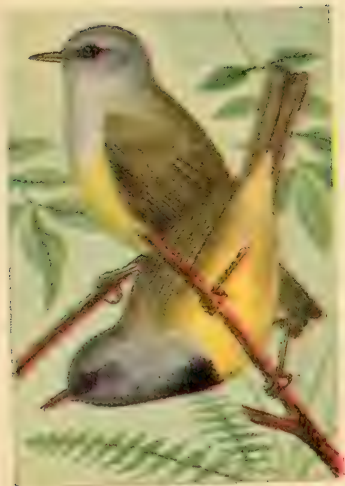

172

\section{IVIOURNING WARBLER.}

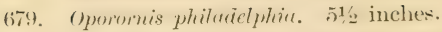

Similar to the last, hut with no eve ring and with a black patch on the breast.

These birds are found in swamps and thickets, as well as ammong the bushes and weerls along walls, fences and the exleges of wouds. Their habits are like these of the Maryland Vellow-thruats, they being fomel an or near the wromel, scratehing about anomg the leates or erleaning insects from the foliage of the low -hrublery. they alpear to he the most abundant in the middle States and northward.

Song.- - imilar to the liquid song of the WaterThrukli: (a)ll, al -hate " "perenk," like that of the last.

Nest.-On or near the ground in thickets or tangled rimes: mate, t fine bark stripe and tibres. linel with hatis: egges white specked with redelish brown $(.71 \mathrm{x} .54)$.

Range.-Eastern $\mathcal{L}^{+}$. 4 .. breeding from northern New England. Ohio and Miehigan north to southern ('anada: winters south of the U. S. 


\section{MARYLAND YELLOW-THROAT.}

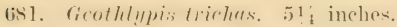

One of our mont common lirds in swatmes aml also in shrublery alomg roadsides or walle. They are very inquisitive, and their bright eyes will peek at you from behind some leaf or shrule as long as you are in sight.

Song.-. lively "witchity-witchity-witeh": call, a deepe chip: also a rattling note of alatrit.

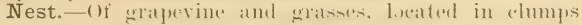

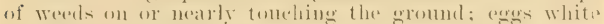
with brown specks $(.70 \times .50)$.

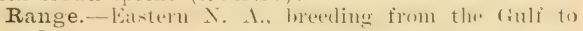
New Jersey.

Sub-species.-6isla. Mintern Yollow-throat iomidentalis), stid to be brighter: found chietly west of the?

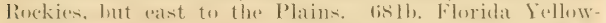

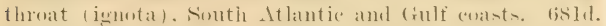
Northera follow-throat (brachidactyla). slightly larger and deeper colored; found in northeasteris C. S. and southeastern ('anadar. West to Daketal and sould through the Missisippi Valley (1) the (iuli.

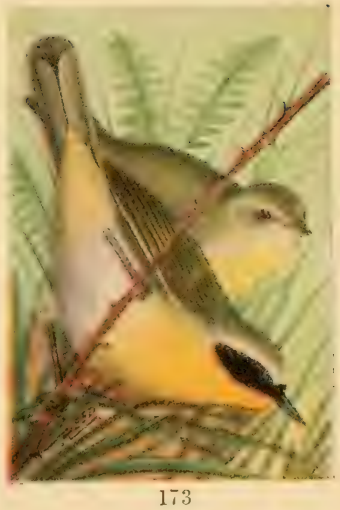




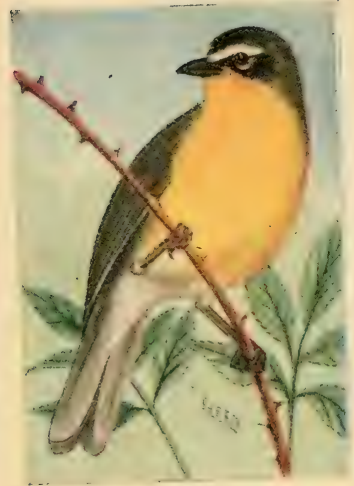

174

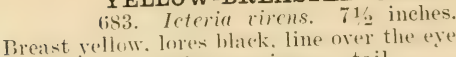
parts white: no white on wings or tail.

Dry side hills and ravines covered with thick under brush are the places to look for (hats. Usually if they are present they will make themselves heard long before rou see them. They are one of the most odd birds both in actiom and song. They are mimies of the highest order and can make any kind of whistle or scputwk, but all their vocal efforts seem to require a great deal of flirting of the tail and twisting of the head. They even jerk their tail up and down while tlying, this making them appear extremely ludicrous.

Songs. - A varied medley of whistles and ealls.

Nest.- Near the wround in tangled thickets: of grass, wereds, ete. : ags whitish plentifully specked with reddish brown $(.90 \times .70)$.

Range.-Eantern [. S., breeding north to Massachusetts and southern Mimesota; winters in ('entral Amer-

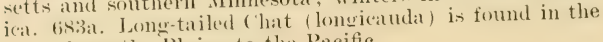
C.S. from the Plains to the Pacific. 


\section{HOODED WARBLER.}

684. Wilsonia citrina. $5^{1 \frac{1}{2}}$ inches.

Male with yellow forehead and cheeks, the rest of the head and throat being black; female much duller with little or no black; both sexes have white spots on the outer tail feathers, but no bars on the wings.

This is one of the liveliest of the family, being very active in catching insects on the wing like a true Flycatcher; because of this habit all the members of this genus are often called Fly-catching Warblers. They also have a habit of often spreading and folding the tail as they flit through the underbrush that they frequent.

Song.-I clear, liquid series of whistles; call, a sharp "chip.",

Nest.- Within a few inches of the ground in low underbrush or vines; made of leaves, bark, etc., held firmly together with colwebs; the four or five eggs are white, profusely spotted with reddish brown.

Range.-Fastern U. S., breeding from the Gulf to southern Connecticut and Michigan; winters south of the U. S.

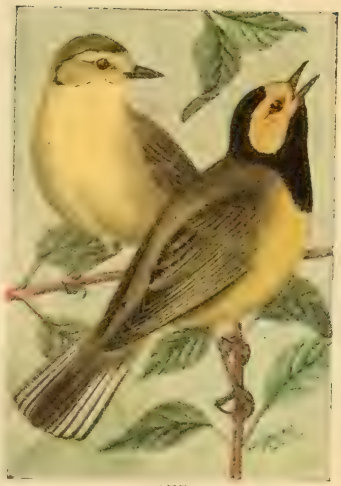

175 


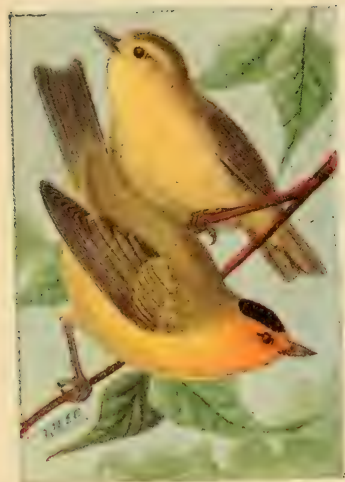

176

\section{WILSON WARBLER.}

685. Milsomia pusilla. 5 inches.

Tale, with black crown pateh; female, with the crown greenish like the back.

The-e little f'r-catching Warblers are abundant in the Inited States during migrations, being fom 1 in woods or swamps, and very often in apple trees when they are in bloom. They fly about anomg the outer brinches snatehing insects from the foliage oi blossoms. and often dashing out to eatch one that is flying hy. Their natural pertness is intensified by their very attractive plumage which harmonizes perfectly with green leaves.

Song.-I simple and rather weak trill.

Nest.-Of loaves and bark. imberded in the gromel muler bushes on the exleges of swampe or wouls; egars white, specked with reddish hrown (.60) x .45).

Range.- Wastern $\mathrm{x}$. \., breeling from the northern e lee of the L. S. northward: winter-in central Imerica. Two sub-species are found west of the liockics. 


\section{CANADIAN WARBLER.}

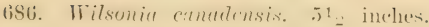

Make. with a necklaer of hlate spets. white eye ring and lores: female, and yome. with only at slight indication of the necklace.

These IVarblers trawel northward in anmpany wit'. many other kinds, always keeping in the mulephomels near the gromul, except when they amse ont inter orchards and patrs. Like the two latet. there are very lively. rarely remainine still for nome than at few seconds, before they munt dash after some tamptims. morsel that is flying by.

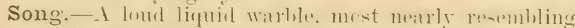
that of the Ifater-Thrush: aall, at sharp, yuerulou- chip).

Nest.- (of routlets and strips of bark, muler roots of trees or shrulse or at the fout of stumps in the moss; the four enge are white with a wreath of chentmut spots aromed the large (and (.6s x .ju).

Range.--bastern X. ... brewling from Massaldumeet ts and Michigan northward: winters in nonthern south America.

12

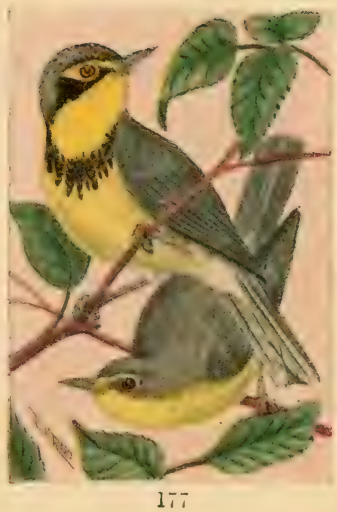




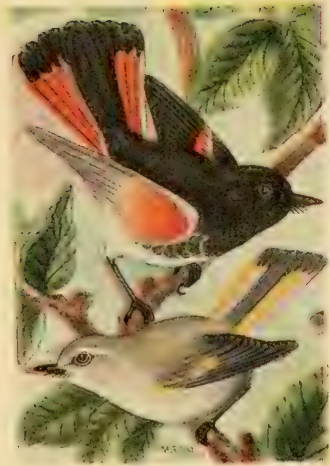

$17 \mathrm{~s}$

\section{AMERICAN REDSTART.}

6isi. Sictophaga rutirilla. 51/2 inches.

Male, black, orange and white: female, grayish, yelluw and white; it requires two or three rears to attin the black plumige of the male, in the intermediate stages they are sometimes strangely mottled.

In the northeastern half of the Lnited States, these ate one of the commonest and mont active of the species. Both the males and females seem to be proud of their handsome plumage and are continually spreading and closing their tails. They are equally happy whether in the tree tops or near the ground, and are as often found in the one place as the other.

Song.- "Che-wee, che-wee, elre-wee," very similar to that of the Fellow Warbler and also the Chestnut-sided IVarbler.

Nest.-Of plant fibres and grasses in forks of bushes or trees, usually at greater leights than those of the Yellow Warbler; eggs whitish specked with brown.

Range.-N. A., rare west of the liockies, breeding from North Carolina and Missouri northward: winters south of the U. S. 


\section{AMERICAN PIPIT; TITLARK.}

697. Anthus rubcscons. $61 \frac{1 / 2}{2}$ inches.

These are Aretic birds that spend the winter months in the Inited States. We find them in flocks along roadsides or in fields, feeding upon weed seeds. They are shy and take wing readily, uttering sharp whistles as they wheel about in the air. They are always restless and stay in a place lut a short time. They nest on the ground in northern Camada. Eggs grayish, profusely specked with brown.

\section{SPRAGUE PIPIT.}

700. Anthus spraguci. $61 / 4$ inches.

Ipper parts streaked with bufl and blackish; below pale buffy with black markings. These hirds are found on the Plains from the 1)akotas to Hudson Bay in summer. migrating to Mexico in winter. They resemble the European skylark in their habit of soaring to a great height while singing. Their song is very melodious. resembling that of the Bobolink. Their nests are depressions in the ground, lined with grasses. Eugrs grayish, finely specked with purplish gray $(.87 \times .67)$.

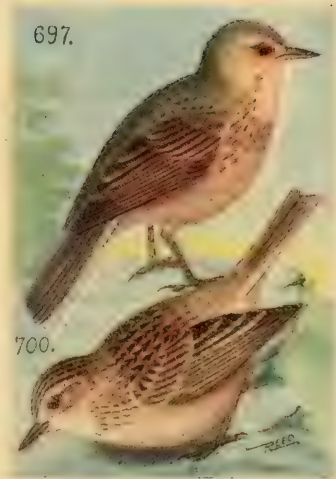

179 


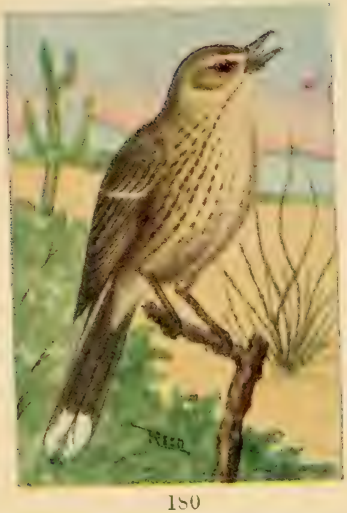

SAGE THRASHER.

702. Oroscoptes montanus. S? inches.

This specien is often known as the Momtain .lockinghird heratue of the brilliance of its song. a very varied performanes. lomg contimmed and moeking that of miny itlier species. They inhabit sage-brush recions and are partial to the lower portions of the enuntry, although frepuently met in open momtains. They are not shy and ran reatily be lowated by their voices.

Nest.-In bushes, eperially the soe and eactus: a louse structure made of bark-strips, -mall twigs and enarse gratsises, lined with tine rootlets. The thee or

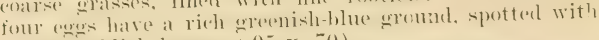
bright reeldish hrown $(.95 \times .79)$.

Range.- Sage-hru-h rewions of western Cnited States from the Platins to the Pacifio: winters in Mexien and Lower California. 


\section{MOCKINGBIRD,}

703. Mimus polyglottos. 101:2 inches.

General colors, graly and white: bases of primaries and outer tail feathers with white.

This is the great vocalist of the south, and hy many is considered to be the most vereatile singer in inerieri. It is foumd in gatrelens, patstures and open woods. All its hahits are similar to our (athird. and like that species it is given to imitating the notes of oflece birck.

Song.-An inclescribable medley. sometimes very sweet and pleasing. at others. harsti and mmm-ioal.

Nest.- comally huilt in impenetrable thickets or hedges. or again in more open situation in the gardens: marle of twigs and roctlets. lined with black roctlets: the four or five roggs are hluish green with blotehes of reddish brown $(.95 \times .70)$.

Range.-, Southem [ . S., breeding north to New deraey (and casually farther) and (fhio: winters in the south Atlantic and fulf States. Fo3ar. Westem Morkinghird (lencopterus) is found in soutlowestern (J.S., north to Indian Territory and (alifornia.

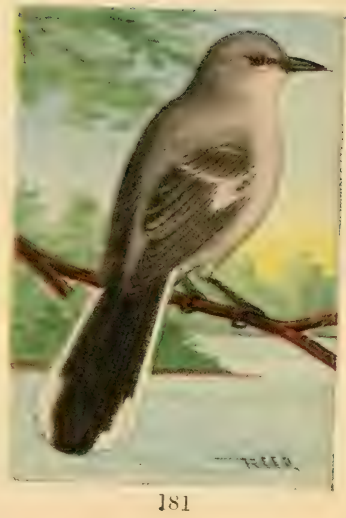




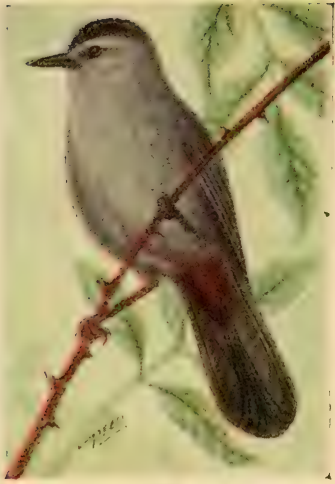

$18^{\circ} 2$
CATBIRD.

704. Dumetella carolinensis. 9 inches.

General color dark gray with a black cap and chestnut under tail coverts.

This is one of the most common birds throughout the Inited States, being found equally abundantly in gardens, swamps and scrubby pastures. They are very persistent songsters and have a large repertoire of notes, as well as being able to imitate those of many other hirds. They delight in spending an hour or more at a time, perched in a bush or tree top, singing, and apparently making their song up as they go along, for it is an indescribable medley interspersed with various mews and cat calls.

Song.-A medley like that of the Mockingbird; sometimes pleasing, sometimes not.

Nest.-In hedges or thickets; made of twigs, rootlets and grass, lined with fine black roots; the four egurs are plain greenish blue $(.95 \times 50)$.

Range.-N. A., breeding from the Gulf to New Brunswick and Hudson Bay; rare west of the Rockies; winters from the Gulf States southward. 


\section{BROWN THRASHER.}

705. Toxostoma rufum. 1113. inches.

Above bright reddish brown: below white with black spots.

Taken as a whole. I think that the song of this Thrasher is the most musieal and pleasing of any that I have ever heard. It has a similarity to that of the cathird, but is romeler. fuller and hats none of the grating qualities of the song of that species. They alpparently have a semg of their own and do not deign ta copy that of others. They are one of the most useful and desirable birds that we have.

Song.-A hright and chereful carol. of ten ling continned. lat alwars clear and sweet: call, a clear whistled "wheuu."

Nest.-of twige and rootlets, in lierloges, thickets or thern bushes: the four or live axges are bluish white with mumerens fine dots of reddish brown over the entire surface $(1.08 \times .80)$.

Range.-Eastern N. A., breeding from the fiulf to sonthern canada: winters in the sonthern half of the I.S.

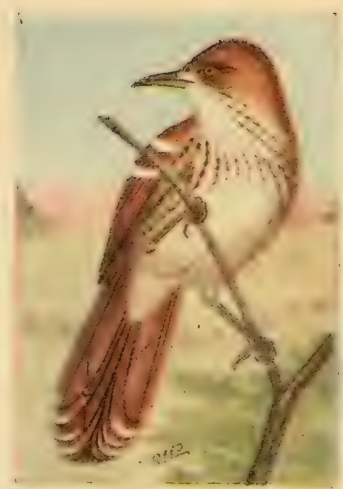

$19: 3$ 


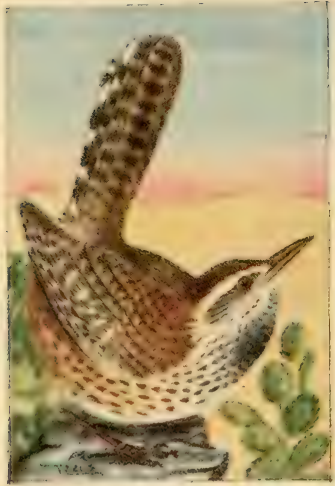

154

\section{CACTUS WREN.}

713. Heleodytes brunncicapiëlus. 81.2 inches.

(actur groves are the farorite resorts of these large Wrens. Giten a bed of cactus not mere than thirty feet sipare will eontain the hemess of half a dozen pairs of them. Like all the members of the family, they are very sprightly and have violent tempers. sending anyone or anylhing that ineurs their displeatsure.

Nest.- Their nests are placed in cactus or other thon ny shrubs: they are very large, purse-shaped athairs with an entration on the sile: they are marle of little thorny twign and grasses woven togetleer, and the interion is warmly lined with farthers. The four or five eage are creamy white. tinely sprinkled with reshlish brown (.9.5 $x$. (i5). Two or three broods are often raised in a season.

Range.-. Sonthwestern border of the C'nited States, rangme from sonthern Texas to California. 


\section{ROCK WREN.}

715. Salpinctes obsoletus. 5":i inches.

Upper parts stome color, specked with black; rump

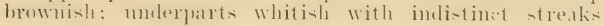
on the throat.

A common bird on the dry, rocky fonthills of the linekies and westwarl. They are weil nomerl. for their favorite places are among the rocks. where they are always busily angaged in hunting insects or spiders in the creviees. Owing to their eolors and their habits of slinking atway behind the reckis they are quite difledelt to see. lout their sweet some is alwats heard if any of the birds are in the vieinity.

Song.- lery sweet atml varied, almost canary-like. but impresible to describe: call. a harsh grating note.

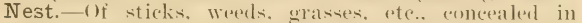
crevices anomg the rocks: the tive or six exges are white, sparingly specked with reddish brown (.7.2. x. $t)$ ).

Range.-IVestern [. S. from the western border of the Platiss to the Pacilice, north to Dakotal and British Columliat winters from southwestern [. S. sonthward.

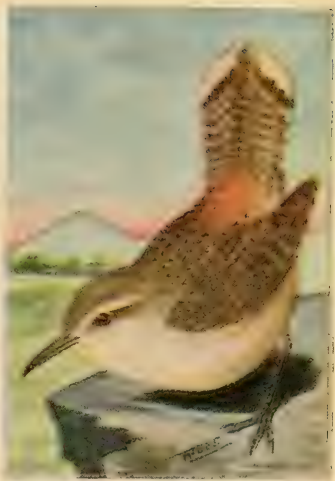

185 


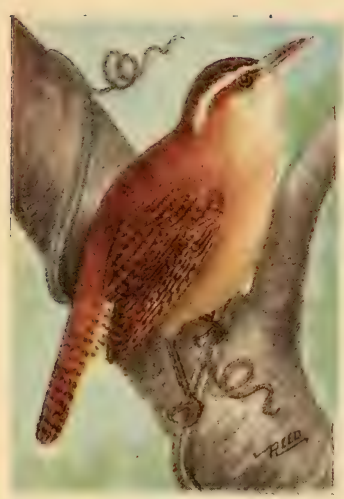

$186 ;$
CAROLINA WRET.

718. Thryothorus ludoricinus. $5^{1} \frac{1}{2}$ inches.

Alowe rusty lorown and below washed with the same, the throat and line over the eye being white.

Tike all the Wrens, this one commonly sits or flits about in the brush. with the tail erect over the body: only when singing is it held downward. Their flight is usually only for a short distance, accomplished by rapid wing beats and with a jerking motion of the tail. Song.-Loud and tinkling, and utterly impossible to describe.

Nest.-In brush heaps, holes in trees, bird boxes or bushes: made of weeds, grass and any trash that they may pick up); eggs, five to seven in number, white. specked with reddish brown $(.74 \times .60)$.

Range.-Eastern [*. S., lneeding from the Gulf nortl to Connectieut and Illimois: resident. 7l8a. Florida Wren (miamensis) is found in sonthern Florida. Fisb. Lomita Wren (lomitensis), found in southern Texas. 


\section{BEWICK WREN.}

719. Thryomancs berickii. 5 inches.

Aiove dark brown: below and line over eye whitish; tail blackish with the outer feathers harred with white.

Like all the Wrens. these seem to be very restless and are eontinually ereeping about in brusin heaps or along stone walls. fenees or orer fallen trees or stumps. They are locally abundant in interior [nited states, in some sections entirely replacing the House Wren.

Song.-A sweet chant of liquid melodionte notes.

Nest.- In any location that happens to take the bird's faner, such as holes in trees. bird boxes, in harns. sheds. ete.; makde of straw, gralso and trash ; eggs white profusely specked with reddish brown.

Range.-Mississiploi Valley and the Planins north to South Dakota: eant to the Alleghanies and cascually to the South Atlantic States. 719e. 'I exas Tewick Viren (eryptus) is found from Texas north to Indian Territory.

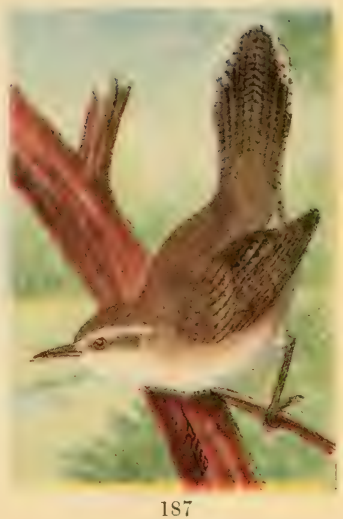




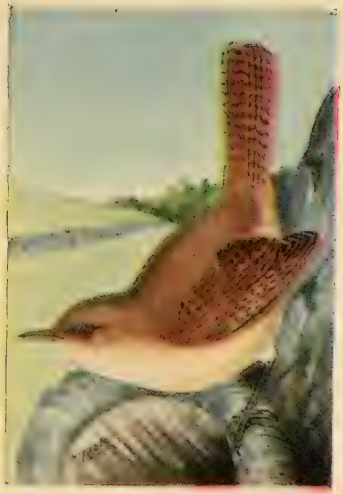

188

\section{HOUSE WREN.}

721. Troglodytes adon. $4: / 4$ inches.

Above brownish with tail and wings barresl; below dull grarish. harred on the flanks with brown.

These are lold, sociable and confiding birkl- seeming to prefer men's society, building their nests in bird boxes that are erecterl for them. or in the most unexpected situations alout buildings. They are one of the most henefieial hirds that ean be attracted to one's yard, feeding wholly upon insects.

Song.-Loud. clear and bulbling over with enthusiasm.

Nest.-Of grass or weeds, stufled into any crevice that takes their fimer, frequently in bird boxes and holes in orehard trees; aggs white, so mimutely and thickly dotted with pinkish hrown as to nearly enceal the gromed color $(.64 \times .52)$.

Range.- Wastern N. A.. breeding north to IIaine and Manitulat: winters along the Gulf coast. Felb. Western House Wren (aztecus) is found from the Plains to the Pacific coast ranges. 


\section{WINTER WREN.}

722. Nannus hiemalis. 4 inches.

Above bright cimmamon, below paler: sides, wings and tail heavily barred with black.

This is the shortest and most stoutly built Wren that we have. They look very pert with their little stubhy tail erecet over their back. In most of the [niterl states we only see them in the winter, and they ane asserciated.

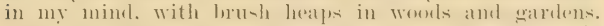
they will hide in a small pile of brush. rumning from side to sile. so that it is almost impossible to make them leave it.

Song. - A rippling flow of melouly. nut is lousl. but more musical than that of the House Wren.

Nest.-In hrush heaps. tin cans. hollow stumps or crevices in monecupied huildings: mate of piles of grater,

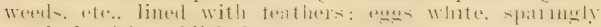
specked with readish brown (.ti.) $\times$..50).

Range.-Eastern N. A. breeding from the northern edge of 1 le $[$. S. northward; winters from its breeding range to the Gulf.

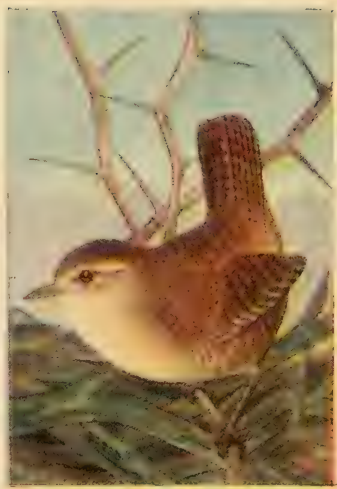

1 s? 


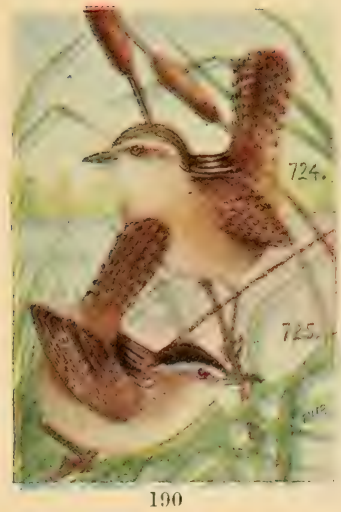

\section{SHORT-BILLED IMARSH WREN.}

721. Cistothorus stcllaris. 51/4 inches.

This species can readily be distinguished from the next, as the whole crown is streaked with black and white, whereas that of the Long-bill is uniformly colored. Both species are marsh birds, at home among the reeds, to which they attach their globular woven nests, with the little entrance in the side. The eggs of this species are pure white. It is found in eastern $\mathrm{N}$. A., from the Gulf to southern Canadil.

\section{LONG-BILLED MARSH WREN.}

725. Telmatodytes palustris. $5 \mathrm{y} / \mathrm{t}$ inches.

The bill of this species is .5 inch or more in length; that of the last is .t inch or less. This species is by far the most abundant. Its eggs are so profusely dotted with dark brown as to appear a chocolate color. Breeds from the Gulf to Massachusetts and Manitobar. 


\section{BROWN CREEPER.}

7.26. Certhia familaris amorictna. 512 inches. Tatil feathers stiflened and pointed: rump rusty. These odal birds are fairly eommom throughont the Lnited states in winter. diey will be fouml in womd always chimbing up tree trumks, carefully investigating every erevice in the hark for larvix or grubs. When they reach the top of one tree, they drop to the foot of the next and contimue the operation. They are very tame, not secming to eomprehend that danger can befall them. for they will allow anyone to approach very closely, so that they have been caught under a hat.

Song.-A very faint trill: call, a weak "tseep," hardly noticeable unless very near them.

Nest.- (of twigs, moss and bark, behind lonse bark on dead trees or stumps. usually not high above the ground: eggs white, specked with reddish brown.

Range.-Eastern $X^{\prime}$. A. breeding from northern Xew England and Minnesota northward: winters throughout the U. S.

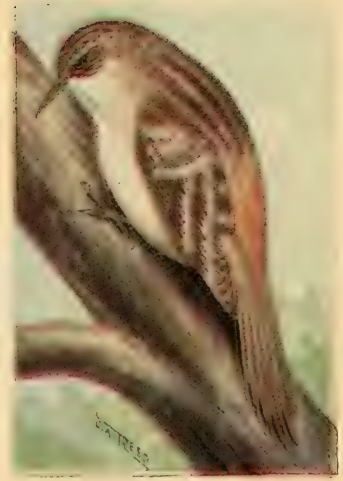

191 


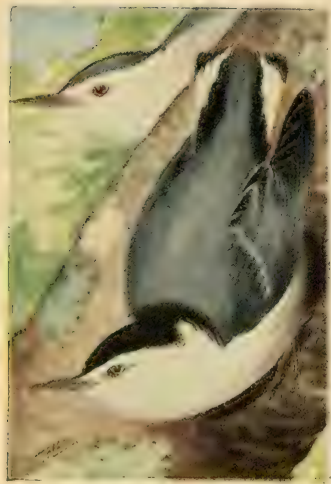

$1 ! 2$

\section{WHITE-BREASTED NUTHATCH.}

727. Sitta carolinensis, 6 inches.

Male with the crown blush blate: temale with the

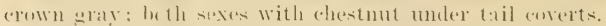

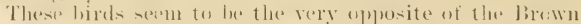
('reepers. Their tails are short and square, and nearly

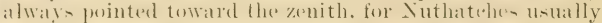

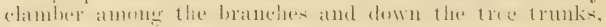
head first.

Note.- I nas:al "Yank-yank," and a 1eperaterl "ya-ya," all on the same tone.

Nest.-In (avitien of hellow limlis ancl trumks of trees at any elevation from the gre.unel: the alvity is

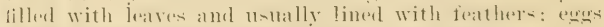

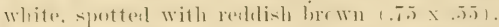

Range.-Fastern [niterd States, breeding from the finlf to southern (itnidil: re-ident in most of it ramge. 7.27). Florida White-hrasted Nuthatch (atkinsi) is slightly smaller: other races are foumd weet of the Rockies. 


\section{RED-BREASTED NUTHATCH.}

728. Silta canadensis. $41 \frac{2}{2}$ inches.

These birds hate the same habits as the larger Nut-

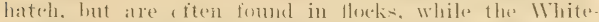

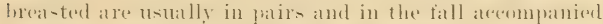
by their roune. In the winter we usually find them in coniferous trees. Whese we ath lecate them by their natsil call or by the shower of bark that they pry from the free in their quest for gruls.

Song.-1 nitsal "yank-limk," like that of the latst. but not as lombl, and insually repeaterl mere times.

Nest.-In Jwellow stmmp and limls. the area about the opening nearly alway: being coated with fir loal sam. for what purpose is not known: the arvity is lined with grasses and feathers: they lay from fome to seren white exge- which are very thickly spottend with redelish brown $(.60 \times .50)$.

Range.-N. I. hreeding from the nort'ern partis of the nortleren tier of states. mortloward: winters south

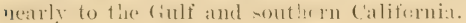

18

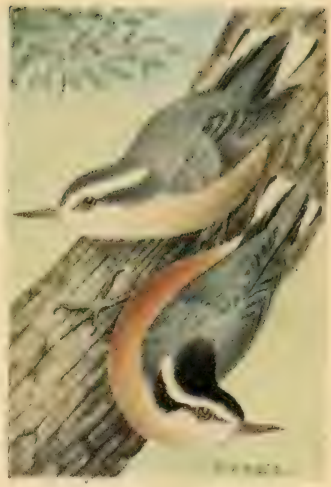

$19: 3$ 


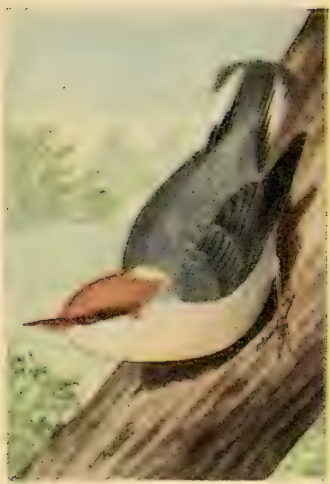

194

\section{BROWN-HEADED NUTHATCF.}

729. Sitta pusilla. $4 \frac{1}{4}$ inches.

('rown brownish with a white patch on the nape.

These diminutive Duthatehes are found in the southern states. Their general habits do not appear to differ from those of other members of the family. They nest very early. commencing to excavate their loles in January and having complete sets of egges as early as the middle of February.

They usually are found in small flocks and at night they will often be seen flying to the top of a pine whiere they sleep, all huddled together.

Notes.- I continued twittering "nya-nya."

Nest.-In cavities of dead limbs or stumps, sometimes only a few inches from the gromid, and again as high as fifty feet; they lay five or six eggrs, white with numerous spots of reddish brown $(.62 \times 5.49)$.

Range.-Couth Atlantic and (iulf states, breeding north to Virginia. 


\section{TUFTED TITMOUSE.}

731. Bccolophus bicolor. 6 inches.

Head crested. forehead black. Hanks brownish. The habits of this large Titmonse are almost identical with those of Chickadeet. They swing from the culs of twigs in all manner of positions and ereep alout trumks peering in crevices of the bark for insects. They are common in the southern states. breeding from the (iult to New York and Illinois; they atre resident in the southern portion of their range. Their exgers are latid in softeneste of down and feathers in hollow stumps. Their notes are loud, clear whistles.

\section{BLACK-CRESTED TITMOUSE.}

\section{Buolophus atricristutus. 6 inches.}

C'rest black, forelead white. flanks rusty. The habits of this species are just like those of the very similar preceding cone. The birds are rery tame, especially so during the nesting season. when they will allow themselves to be lifted from the nest ly hand. They are foum in southern and western Texas.

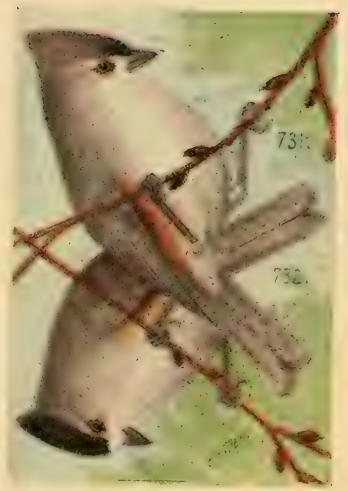

195 
735.

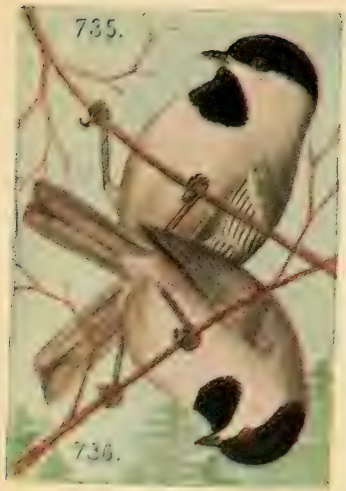

\section{BLACI-CAPPED CHICKADEE.}

735. Penthestes atricapillus. $5 \frac{1}{1} / 4$ inches.

The chickateres are one of the most popular birds that we have, owing to their uniform good nature even in the coldest weather, and their confiding disposition. They are common ahout farms and even on the outskirts of large cities they will come to fealsts prepared for
them on the window sill.

Notes. - I dear "phe-he" : a "chick-a-dlee-dee-dee" or

"derederedee, and sereral scolding or chuckling notes.
Nest.-1n hollow stmmps at any elevation from the croumel hut nowally near the ground, and most often in birch stuhs: egos white, sparingly specked with reddish

Range.-Fastern X. A. breesling in the northern half of the l. S. and northward: resident.

7isti. Carolina (licklatee (Parus carolinensis) is similar to the last hut smaller and with no white edges to the wing feathere: length $4^{1}$.. inches: fomm in south. eastern L. ..., breeding north to Vireginia and Ohio. 


\section{HUDSONIAN CHICKADEA.}

\section{I'enthestes hudsonicus. 5 inehes.}

Crown and back brownish.

The habits of this little northerner ane like those of the bird that we know on well; if an thing ther are even more tame than our hird, espectally in the vicinity of lumbermen's camps. They are only met with along our northern border or easually farther south; 1 have seen one individual in company with other chickadees in Massachusetts.

Song.- Not distinguishalle from that of omr (hickadee. lut uttered more incesisatitly.

Nest. - In cavities of stumprs, trees. posts or telephone poles, the earity being lined with gratsis, feathers and fur ; the six or seven exges are white sprinkled with brown $(.60 \times .46)$.

Range.-liesident in Canalia and the northern border of the U. S.

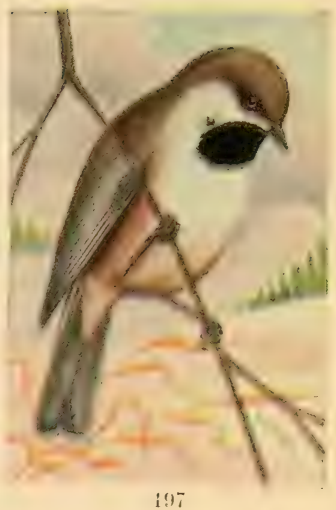




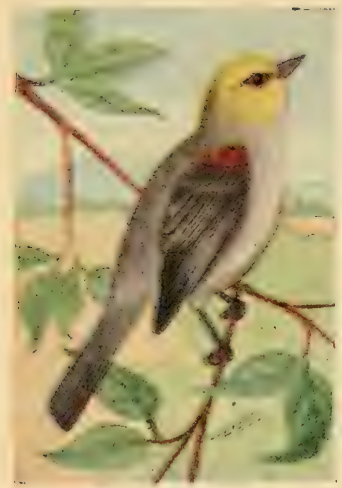

108

\section{VERDIN; YELLOW-FEADED TIT.}

746. Auriparus fariecps. $4 \frac{1}{4}$ inches.

Adult male with the heal and throat yellow, usually with some eoncealed orange-hrown on the forehead: lesiser wing-coverts reddish bown. The female as colored rery similarly, but is mucls duller. These are among the smallest of $\mathrm{N}$. A. hirds: they are 'ven smaller than their length would indicate, for their bodies are slender. The biris are usually found in high dry portions of the country where cacti and thorny bushes predominate.

IVest.- Ilueir nests are remiarible structures for so diminutive lirds; flask-shaped, the outside being a mass of thorny twigs and stems interwoven: thes is loned with feathers and the entrance is a small cirenlar hole near the top. 'The eggs are bluish white spectied around the large end with reddish brown.

Range.-Mexican boler of the United Sitates from sonthern Texas to Arizona and Lower ('alifornia. 


\section{GOLDEN-CROWNED KINGLET.}

748. Regulus satrapa. 4 inches.

Iale with crown orange and yellow, bordered with black; female with yellow crown.

Althoigh very small, these birds are very rugged and molure the severe storm and low temperatures of our northern states apparenty with little eneern, for they always sem to be hapey. They are always busily engaved among the underbrush of side hills and along the hamlis of brooks, hunting for the seanty fare that awaits them.

Song.-A few weak chips, chirps and trills.

Nest.- I large ball of soft green mosices and feathers, suspended from the small twigs in the tops of coniferous trees; it is neatly hollowed out for the reception of the six to nine egges that are laid: egges creamy white, minutely but profusely specked with brown (.56 x .44).

Range.- $\mathrm{X}$. A., breeding from northern $\mathcal{L}$. S. northward and farther south in mountain ranges; winters throughout the U. S.

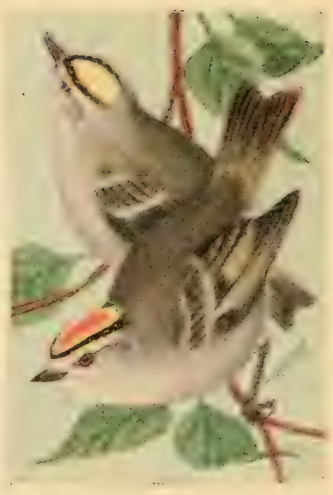

199 


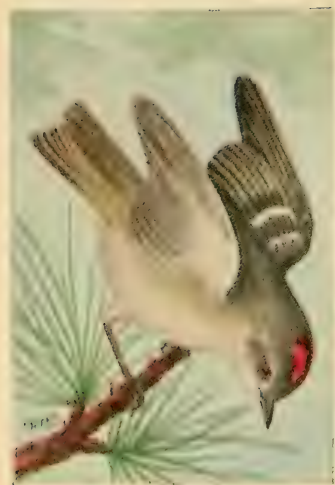

200

\section{RUBY-CROWNED KINGLET.}

it!. licyulus culculula. $\$ 1 \frac{1}{4}$ inches.

Mate with a concealed patch of red on the crown: female with no red.

Like the last. these are chielly winter visitants in the Tnited states and they do not remain with us in the coldent weathere. lut paiss on to the sonthern half of one (e) other coniforome trees, being very abundant in spring in open pine woods and parks.

Song.-A reatr warble, sumprisingly loud and varied for xos small a lird: call, a gratting vinatter.

Nest.-A ball of mosis, gratis and feathers, derply cupped. like that of the last : partially suspended amonge the small twigs in the tops of emoferous trees: exgess white. more sparingly matkerl than those of the last $(.55 \times .43)$.

Range.-X. A., brexeling northward from the northeren boumelary of the $\mathrm{C}$. S. and farther south in mesurtains: winters in the southern late of the $\mathrm{L}$. S. 


\section{BLUE-GRAY GNATCATCHER.}

751. Polioptile carulea. $41 / 2$ inches.

Forehearl black: tail blatek with white erlges and tijes to the outer ones.

their fored is chiefly insert-, which they are very exlert in eatching. taking them on the wing with incent frem one part of asements are all very rapid. flitting

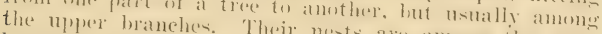

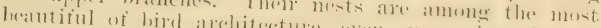
the Hummingbird.

Song.- - weret. lint very faint.

Nest.-Situated on lwirizental limb of trexs at mes

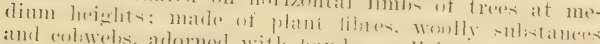

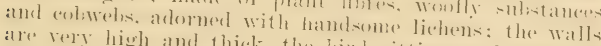
atre lere high and thick. the birl sitting so low inside? that wily her tat is visihle: the fort of five cegers are

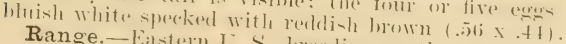

Range.-Eastern L. S., breeding north to New dersey

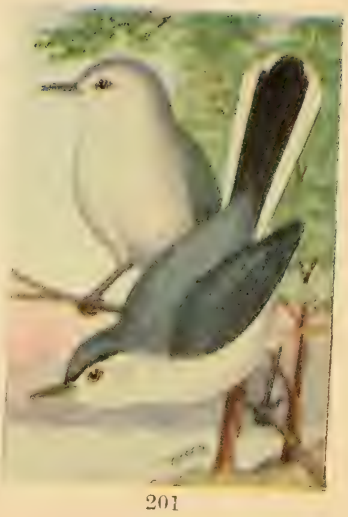




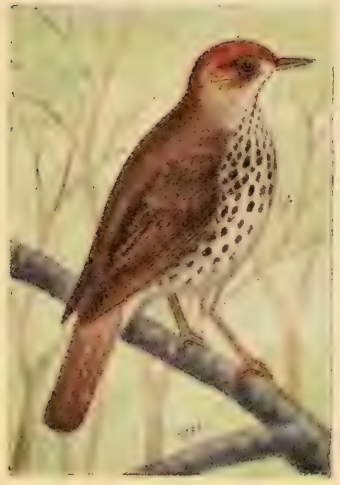

202
WOOD THRUSH.

755. Hylocichla mustclina. 8 inches.

lieddisin hrown alove, brightest on the head; below white heavily spotted with black.

These large 'thrushes are locally abundant in swamps and moist woodland. They are one of our best songsters, their tones heing very rich and dlute-like, and, like most of the Thrushes, their songs are most often heard along toward night.

Song.- - Very clear and llute-like, containing many notes of the scale; often two or more birds answer back and forth from diflerent parts of the woods; calli, a sharp "quit, quit" and a liquid "quirt."

Nest.-Either in forks or on hori\%ontal boughs of buslies or trees, usually not more than ten fert from the ground: made of grass, weeds, leaves and some mud; the three or four eggs are bluish green $(1.02 \times .75)$.

Range.-Fastern U. S., breeding from Virginia and Missomri north to Maine, Ontario and Mimnesota; win. ters south of the U. S 


\section{WILSON THRUNH OR VEERY.}

750. Ilylocichla fusecesens. $\tau^{\top}$; inches.

Entire upper parts a miform redaisit bown: below soiled white with a few faint marks on the breast.

Thus species is more abundant than the last. It is found in swamps and also in dry open worels, they lacing especially numerous where ferni grow luxuriantly.

Song.- Tery peeuliar and not nearly as melodions as that of the Wiod Thrush, hut still attractive: a slightly descending "too-whe-u-whe-u-whe-u"; call, a cleal "whe : yol1."

Nest.-On the ground among the leaves, on hummocks, or in tangled masses of briars: made of strips ef lark and leaves; eggs greenish blue, darker and smalies. than those of the Wrood Thrush (.8s $\times$.65).

Range.-Eastern $\mathrm{N}$. A., breeding in the ntrthern laalf of the Enited States and sonthern ('anada: wintes s in Central America. T56a. Willow Thrush (salicienla) is more olive above; it is found in the Rockies and eastward to the Mississippi River.

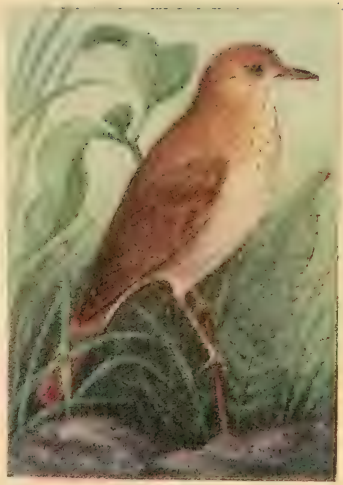

203 


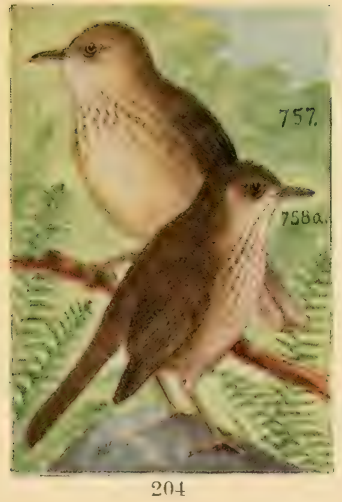

GRAY-CHEEKED THRUSH.

757. Mylocichla alicia. T1!2 inches.

Quite similar to the following but with the eve ring white and the sides of head and breast much palere.

Breeds in northern canada and migrates through the eastern states to Central America. Fora. Bicknell Thrush (bicknelli) is similar to the Gray-cheeked but smaller. It breeds in Nora Scotia.

\section{OLIVE-BACKED THRUSH.}

7.jsia. Hylocichla ustulata surainsonii. 71,t inches.

Cpper parts wholly olive gray, with no hrownish tinge: eye ring, sides of head and breast distinctly bufl; breast spotted with blackish.

Song. - Suite similar to that of the Veerr.

Nest. - (omposed of leaves. grass and strijs of hark, located in bushes or small trees near the gromul: the four exgs are greenish blue spotted with reddish brown $(.90 \times .65)$.

Range.-Fastern $\mathrm{X}$. A. loreeding from mothern L'. S. to New Brumswick and Mamitoba. 


\section{HERIIT THRUSH.}

7.job. Hylocichln guttatu pallasii. $6 \%$ inches. Tail redulish brown. much brighter than the back and head: breast quite hearily spotted with black.

During its migrations it rarely sings but in its summer home it is regarded as a remarkable musician. Its song hats the sweetness and purity of tone of that of the Wood Thrush, and is, perhaps, more varienl, but it is not nearly as powerful, and has a ventriloquial affect. I watehred one that was percherd on a dead stump, about twenty feet from me. for sereral mimutes with a pair of glas-es before. I coulel make sure that loe wats the author of the somg I heard. for it sommled as thourh (roming from arerosin the next field.

Nest.-Cimilar to that of the Wrilson Thrush and like that. places on the gromel or rery ne:lie it: the

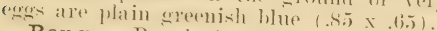

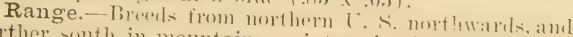
farther south in mountains: winters in the Gru? States.

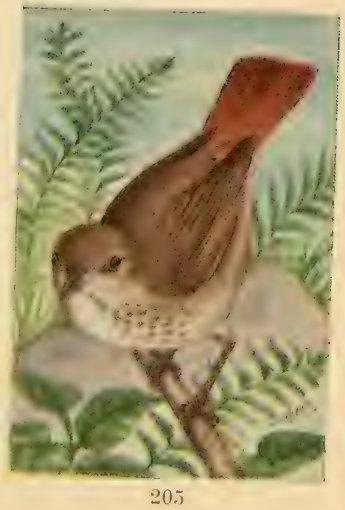




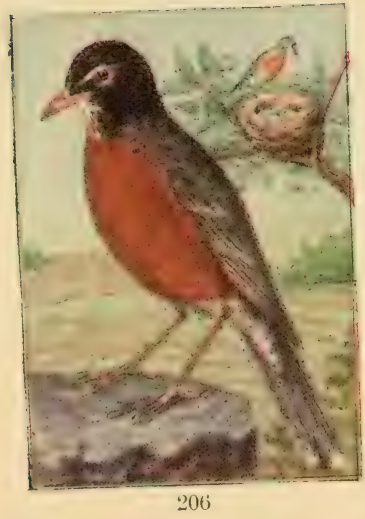

\section{AMERICAN ROBIN.}

761. Planesticus migratorius. 10 inches.

Male with a black head and bright reddish-brown breast: female with a gray head and much paler breast; voung intermediate hetween the two and with a reddishirown breat spotted with black.

These well-known birds are very abundant in the northern laalf of the [nited States, being found most (ommonly ahout farms and dwellings in the country, and also in eities if they are not persecuted too severely by English Sparrows.

Song.-I lom cheery carol, "cheerily-cheerup, cheerily-cheerup," often long continued.

Nest.-1 coarse but substantial structure of mud Nest.-
and grass. placed on horizontal boughs or in forks at
any height, or in any odd place about dwellings: the four or fire exgs are bluish green $(1.15 \times .80)$.

Range.-Eastern X. 1. breeding from the midlle of the $\left[\right.$. S. northward: winters throughout the $\mathcal{L}^{*}$ S. 761b. Southern Roloin (achrustera) is a paler form found in the Carolinas and Georgia.

\section{6}




\section{GREENLAND WHEATIAR.}

705a. Saxicolt wnanthe lencorrthor. 6 inches.

The Wheatear is a European hird, but this sub-species is foumd in fireenland and oceasionally in Labrader.

Their habits are about the same as those of the Bhuebird. They feed upon inseets, larre, fruits, berries and some seeds. They are essentially ground birds and are nsually found in rocky country.

Nest.-Their nests are made of grasses, hair or any rubbish obtainable. and are hidden in the inmermost recesses of erevices among rocks, in deserted Bank Swallow nests or even in rabbit burrows.

The four to six exgs are pale greenish blue, a little brighter in shade than those of the Bluebird. They

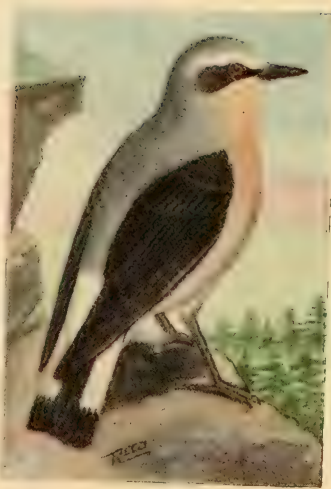




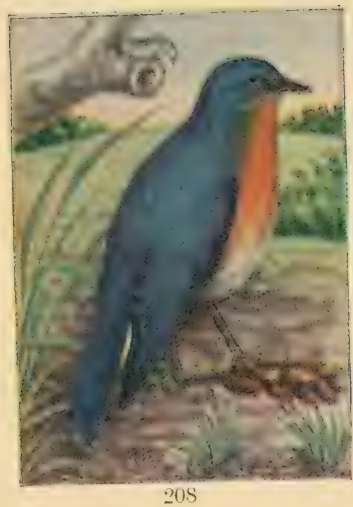

\section{BLUEBIRD.}

766. Sialia sialis. 7 inches.

These beantiful, antle and weli-known hirds spend lle winter in the southern parts of the Linited states and north to the smow line: some more hardy that the seat are fouml throughont the winter in soritherm xiew England.

Call.- A short sweet warlole; somg. al continued warbling.

Nest.-In hules in troes, particularly in orchards. in bird boxes or cannies about the huildings. The losttom of the eavity is lined with gratsen for the reseption of the four or five pale liluish engs, which meature $.84 \times .62$.

Range.-Fastern Initerl States, breding from the Gulf to Xew linumswick and Manitobal: winters ehiefly in the southern parts of the Inited states. Fitial.

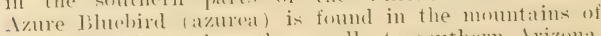
eastern Texien and north (as sully to southern Arizmal. It is paler both above and helow than our eastern bird. 


\section{FIELD KEY FOR IDENTIFICATION OF EASTERN LAND BIRDS BY CONSPICUOUS MARKINGS.}

We have added this liey at the request of many of our readers for a color scheme for identification. It includes all the birds that have markings of sufficient
prominence to be readily noticed in the field.

\section{BIRDS WITH RED OR ORANGE MARKINGS.}

Scarlet body; black wings and tail; $71 \frac{1}{2}$ in.-SCARLET TANAGER. Red; darker above; crested; black face; in.-CARDINAL. Rosy-red; wings and tail slightly darker; $71 / 2$ in.-SUMMER TANAGER.

Rosy-red; white wing bars: crossed bill; 6 in.--IVHITE-IVINGED CROSSBILL. Rosy-red; Gray back, wings and tail; stout bill; $\$ 1 / 2$ in.-PINE GROSBEAK. Brick-red; wings and tail darker; crossed bill; 6 in.-CROSSBILL. Purplish-red, streaked with darker; dark wings and tail.-PURPLE FINCH. Red below; blue head; yellow back; 51/2 in.-PAINTED BUNTING. Red patch on crown (concealed): greenish back; 41/2 in.-KINGLET, Red cap; black chin; rosy breast; streaked; $51 / 4$ in.-REDPOLL. Pink breast and under wings; black head and back: 8 in.-ROSE-BREASTED Ruby throat; metallic green back; tiny birds-HUMMINGBIRD. 
Orange-red under wings and patch on crown; long forked tail.-SCISSOR-TAILED FLYCATCHER.

, )range; black head, wings and tail (marked with yellow)-BALTIMORE ORIOLE. Orange breast, crown patch and above eye; black and white back, wings and tail -BLACKBURNIAN WARBLER.

Orange crown patch, edged with black; green back; 4 in.-KINGLET.

Orange on sides, wings and tail; black above; $5 \frac{1}{2}$ in.--REDSTART.

Orange-brown crown edged with black; green back; spotted breast-OVENBIRD.

\section{BIRDS PROMINENTLY MARKED WITH BLUE.}

Blue, shading to purplish on head; $5 \frac{1}{2}$ in.-INDIGO BUNTING.

Blue; chestnut shoulders; black face; 7 in.-BLUE GROSBEAK.

Blue above; brownish breast; 7 in.-BLUEBIRD.

Blue above; black collar, bars on wings and tail (also white)-BLUE JAY.

Pale Blue above and streaks below; white on wings and tail-CERULEAN IVARBLER.

Dark blue above; black throat and sides; white on wing-BLACK-THROATED BLUE WARBLER.

Light blue head and back; brown breast; $5 \frac{1}{2}$ in.-LAZULI BUNTING. 


\section{BIRDS WITH YELLOW AS PROMINENT COLOR.}

Yellow below; green back; black mask-MARYLAND YELLOWTHROAT. Yellow below; gray head and breast; $5 \frac{1}{2}$ in.--MOURNING IVARBLER.

Yellow below; gray head and breast; white eye ring-CONNECTICUT IVARBLER.

Yellow below; black crown and ears; yellow over eye-KENTUCKY WVARBLER. Yellow below; green back; brown spots on back; black stripes on side-PRAIRIE IVARBLER.

Yellow below; green back; brown crown and strealis on side; white on tailPALM WARBLER.

Vellow below; green back; yellow crown; brown stripes on sides-YELLOW IVARBLER.

Yellow below; green back; brown ear patch and streaks on sides-CAPE MAY IVARBLER.

Yellow below; green hack; brown patch on crown; head gray above-NASHVILLE WVARBLER.

Yellow below; green back; orange-yellow head; white on tail-PROTHONOTARY IVARBLER. 
Yellow forehead, ears and below; green back; cap and throat black-HOODED WARBLER.

Yellow breast; gray back; black spotted necklace-CANADIAN WWARBLER.

Yellow breast; green back; gray head; white over eye-YELLOW-BREAS TED CHAT.

Yellow breast; gray back; black through eye and down sides-YELLOW: THROATED IVARBLER.

Yellow breast; yellowish patch on back; brown on throat-PARULA WARBLER.

Yellow breast; green above; black throat and down sides-BLACK-THROATED GREEN WARBLER.

Yellow breast with black crescent; streaked above; 11 in.-MEADOWLARK.

Yellow above and below; black cal, wings and tail-GOLDFINCH.

Yellow head; black body; white patch on wing-YELLOW-HEADED BLACKBIRD.

Yellow head; gray body; brown on shoulders; $4 \frac{1}{2}$ in.-VERDIN.

Yellow crown; chestnut on sides; streaked above-CHESTNLT-SIDED IVARBLER.

Yellow below and on rump; black back and spots on breast-MAG.NOLA IWARBLER.

Yellow llatch on crown, rump and side; streaked with gray above-MYRTLE WARBIER. 


\section{BIRDS WITH BROWN MARKINGS MOST PROMINENT.}

Small brown birds ( 4 to 6 in.) with barred wings and tail-WRENS. Iniform brown above, gray below; long broad tails-CUCKOOS. Bright reddish brown above; spotted breast; 111/2 in.-BROWN THRASHER. Brown body; black head, wings and tail; $7 \frac{1}{2}$ in.- ORCHARD ORIOLE. Reddish brown breast; slate back; dark head; 10 in.-ROBIN. Dull brown back; grayish, more or less spotted breasts-THRUSHES. Brown belly; black crown and stripe through eye; gray back-NUTHATCH. Streaked brown and white; curved bill; climbs up trees-BROWN CREEPER. Brownish gray; crested; yellow tip to tail; black through eye-IVAXIVING. Brown crown, throat and streaks on sides; black mask-BAY-BREASTED WARBLER.

Brown sides: black head, throat and back: white on wings and tail-TOWHEE. Brown rump and tail; gray back; strealied above and below-GOX SPARROW. Brown shoulder, yellow breast patch; black on throat-DICKCISSEI. Brown shoulder; streaked above; white outer tail feathers-VESPER SPARROW. Brown shoulder; black eap and patch on breast-IlcCOWN LONGSPLR. Brown nape; black breast and cal); light throat-CHESTNUT-COI.L.ARED I.ONGSPUR. 


\section{SHARPLY DEFINED BLACK AND WHITE MARKINGS.}

Black crown and throat; gray back; 5 in.-CHICKADEE.

Black and white streaked bird; black crown; 5 in.-BLACK POLL WARBLER. Black and white streaked bird; striped crown-BLACK AND WHITE WARBLER. Slate head, breast and back; white below and outer tail feathers-JUNCO.

White throat; gray breast; crown striped black and white-WHITE-THROATED SPARROW.

Large white crown patch edged with black; light below-WHITE-CROWNED SPARROW.

Black body; yellowish nape; white rump and on wings-BOBOLINK.

Black crown; gray back; climbs down trees-IVHITE-BREASTED NUTHATCH. Dull gray birds with no markings may be FLYCATCHERS.

Dull brownish, streaked birds are probably species of SPARROWS.

Plain greenish backs and dull white underparts denote VIREOS.

Glossy blackbirds are GRACKLES or CROWS; if with red shoulders, RED-WINGED BLACKBIRD; with dull brown head, COWBIRD. 


\section{CLASSIFIED TABLE OF EASTERN LAND BIRDS.}

Showing Divisions into Orders, Families and Genera, as Adopted by the American Ornithologists' Union.

ORDER PSITTACI. Parrots, Macaws, etc.

Family PSITTACID E. genus

CONUROPSIS.

Carolina Paroquet.

ORDER COCCYGES. Cuckoos, Kingfishers, etc.

Family CUCULID‡. Genus

CROTOPHAGA.

GEOCOCCYX.

COCCYZUS.

Family ALC'EDINIDE. Genus

CERYLE.

ORDER PICI. Woodpeckers.

Family PICID A: Genus

CAMPEPHILUS.

DRYOBATES.

PICOIDES.

SPHYRAPICLS.

PHILGETONITS.

HELANERPES.

Anis

Road-runner.

Cuckoos.

Kingfishers.

Ivory-billed Woodpecker.

Hairy to Texan Woodpeclier.

Three-toed Woodpeckers.

Sapsuckers.

Pileated Woodpectiers.

Red-headed Woodpeckers. 
Family PICIDA. Genus
CENTURUS.
Red-bellied Woodpeckers. COLAPTES.
Flickers.

ORDER MACROCHIRES. Goatsuckers, Swifts, Hummingbirds, etc.

Family (CAPRIMIILGID.E. Genus

ANTROSTOMUS.

PHAL.ENOPTILIS.

Whip-poor-will.

NYCTIDROMUS.

CHORDEILES.

Family MICROPODII) E. ('enus

('H.ETLRA. ERONAUTES.

Fa:ily TROCHILID.E. Genus

TROCHILUS.

OREER PASSERES. Perching Birds.

Family TYRANNID.E. Genus

MUSCIVORA.

TYRANNUS.

PITANGUS.

MYIARCHUS.

SAYORNIS.

Poorwill.

Paraque.

Nighthawlis.

a'himney Swift.

White-throated Swift.

Ruby-thr. Hummer.

Scissor-tail Flycatcher.

Kingbirds.

Derby Flycatchers. Crested Flycatchers.

Phoebes. 
Family TYRANNIDA. Genus

NUTTALLORNIS.

MYIOCHANES.

EMPIDONAX.

PYROCEPHALUS.

Family ALAUDIDA. Genus

OTOCORIS.

Family CORVIDAE. Genus

PICA.

CYANOCITTA.

APHLECOMA.

XANTHOURA.

PERISOREUS.

CORVUS.

NUCIFRAGA.

Family STURNIDA. Genus

STURNUS.

Family ICTERIDA. Genus

DOLICHONYX.

MOLOTHRUS.

XANTHOCEPHALUS.
Olive-sided Flycatchers. Pewees.

Least Flycatchers.

Vermilion Flycatchers.

Horned Larks.

Magpie.

Blue Jays.

Non-crested Jays.

Green Jay.

Canada Jay.

Crows and Ravens.

Clarke Nutcracker.

Starling.

B bolink.

Cowbirds.

Yellow-head Blackbird. 
Family ICTERIDA. Genus

AGELAIUS.

STURNELLA.

ICTERUS.

SCOLECOPHAGUS.

QUISCALUS.

Family FRINGILLIDAE. Genus

HESPERIPHONA.

PINICOLA.

CARPODACUS.

LOXIA.

LEUCOSTICTE.

ACANTHIS.

ASTRAGALINUS.

SPINUS.

PLECTROPHENAX.

CALCARIUS.

RHYNCOPHANES.

POCECETES.

PASSER.

PASSERCULUS.

Red-winged Blackbirds. Meadowlarks.

Orioles.

Rusty Blackbirds

Grackles

Evening Grosbeak

Pine Grosbeaks.

Purple Finches.

Crossbills.

Leucostictes.

Redpolls.

Goldfinches.

Pine Siskin.

Snowflakes.

Longspurs.

McCown Longspurs.

Vesper Sparrow. English Sparrow.

Ipswich Sparrow. 
Fanily FRINGILLID王. Genus

COTURNICULUS. AMMODRAMUS.

CHONDESTES.

ZONOTRICHIA.

SPIZELLA.

JUNCO.

A.IPHISPIZA.

PEUC EA.

MELOSPIZA.

PASSERELLA.

PIPILO.

OREOSPIZA.

CARDINALIS.

PYRRHULOXIA.

ZAMELODIA.

GUIRACA.

PASSERINA.

SPOROPHILA.

SPIZA.

CALAMOSPIZA.
Grasshopper, Leconte. Sharp-tail Seaside.

Lark Sparrow.

Harris and Crowned Spar.

Chippy, Tree, Field.

Juncos.

Black-throated, Bell. Pine-wood Sparrow.

Song, Swamp Sparrow.

Fox Sparrow.

Towhees.

Green-tailed Towhee.

Cardinal.

Pyrrhuloxia.

Rose-breast Grosbeak.

Blue Grosbeak.

Buntings.

Seed-eater.

Dickcissel.

Lark Bunting. 
Family TANAGRID.E. Genus PIRANGA.

Family HIRUNDIOID. E. Genus PROGNE. PETROCHELIDON. HIRUNDO. IRIDOPROCNE. RIPARIA. STELGIDOPTERYX

Family BOMBYCILLID E. Genus BOMBYCILLA.

Family LANIID E. Genus LANIUS.

Family VIREONIDE. Genus VIREOSYLVA. LANIVIREO. VIREO

Family MNIOTILTID E. Genus MNIOTILTA. PROTONOTARIA. HELINAIA.

Tanagers.

Purple Martin. Cliff Swallow. Barn Swallow. Tree Sivallow. Bank Swallow. Rough-wing. Swallow.

Waxwings.

Shrikes.

Red-eye., Warbling Vireo. Yell.-thr., Blue-head.

White-eye Vireo.

Black and White Warbler. Prothonotary.

Swainson Warbler. 
Family MNIOTILTID $Æ$ Genus

HELMITHEROS.

HELMINTHOPHILA.

COMPSOTHLYPIS.

DENDROICA.

SEIURUS.

OPORORNIS.

GEOTHLYPIS.

ICTERIA.

WILSONIA.

SETOPHAGA.

Family MOTACILLID E. Genus

ANTHUS.

Family TROGLODYTIDA. Genus

OROSCOPTES.

MIMUS.

DUMATELLA.

TOXOSTOMA.

HELEODYTES.

SALPINCTES.

THRYOTHORUS.
Worm-eating Warbler. Bachman to Tennessee. Parula Warbler.

Cape May to Palm Warbler.

Oven-bird, Water-Thrush.

Ky., Conn., and Mcurning.

Yellow-throats.

Chat.

Hooded to Canadian.

Redstarts:

Pipits.

Sage Thrasher.

Mockingbird.

Catbird.

Thrashers.

- Cactus Wren.

Rock Wren.

Carolina Wren. 
Family TROGLODYTID.E. Genus

THRYOMANES.

TROGLODYTES.

NANNUS.

CISTOTHORUS.

TELMATODYTES.

Family CERTHID AE. Genus

CERTHIA.

Family PARID无. Genus

SITTA.

BAOLOPHUS.

PENTHESTES.

AURIPARUS.

Family SYLLVIIDE. Genus

REGULUS.

POLIOPTILA.

Family TURDIDE. Genus

HYLOCICHLA.

PLANESTICUS.

SAXICOLA.

SIALIA.
Bewick Wren.

House Wren.

Winter Wren.

Short-bill Marsh Wren.

Long-bill Marsh Wren.

Brown Creeper.

Nuthatches.

Titmice.

Chickadees.

Verdin.

Kinglets.

Gnatcatchers.

Thrushes.

Robins.

Wheatear.

Bluebird. 
、 


\section{I D E X}

Ani, Groove-billed ............ 1s

Blackbird, Brewer ................ 71

Blackbird, Fed-winged ............ 65

Blackbird, Florida ............. 65

Blackbird, Rusty .............. 71

Blackbird, Yellow-headed ........ 64

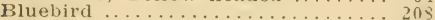

Bluebird, Azure ................. $20 \mathrm{~s}$

Bunting, Black-throated ......... 12,

Bunting, Indigo ................ 117

Bunting. Lark .......................... 123

Bunting, Lazuli ................... 11 . . .

Bunting, Varied ................. 119

Bunting, Painted ..................... 120

Bobolink ................... 62

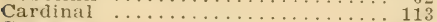

Catbira .................... 182

Chat, Yellow-breasted ............... 174

vebec ............................ 51

ewink .................... 111

nickadee, Black-capped ........... 196

Chickadee, Carolina .............. 196

Chickadee, Hudsonian ............ 197

Chuckwill's Widow ............... 34

Cowbird ................... 63

Creeper, Brown ................. 191
Crossbill, American . . . . . . 77

Crossbill, Whitewinged .......... 76

Crow, Imerican ............... 59

Crow, Clarke ................... 60

Crow, Fish .................. 5

Crow, Floridei ................. 59

Cuckoo, Black-billed ........... 20

Cuckoo, Mangrove ................... 19

Cuckoo, Yellow-billed …..................... 19

Dickcissel ................. 122

Finch. Purple ............. 75

Flicker . . . . . . . . . . . 32

rlicker, Iied-shafted ..........

Flycatcher, Acadian ................ 50

Flycatcher, Crested ........... 46

Flycatcher, Derby ............. 45

Flycatcher, Green-crested ....... 50

Flycatcher, Least ............. 51

Flycatcher, olive-sided ........... 48

Flycatcher, Seissor-tailed ........ 41

Flycatcher, Termilion ......... 5

Flycatcher, Yellow-lellied ......... 50

Gnateatcher. Blue-gray .......... „01

Goldfinch, American ........... 80

Goldtinch, Arkansas ............. $\$ 1$

Grackle Boat-tailed a. 79 
Grackle, Bronzed ............ 7 :

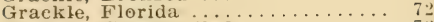

Grackle, Great-tailed ............

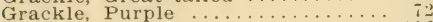

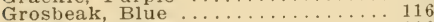

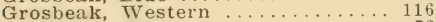

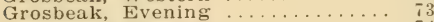

Grosbeak, Pine ................

Grosbeak, Rose-breasted .......... 115

Hummingbird, Ruby-throated ..... 40

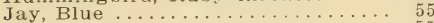

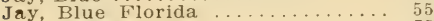

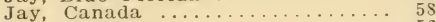

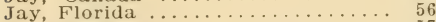

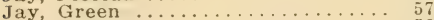

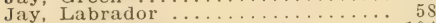

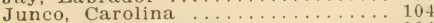

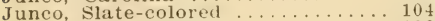

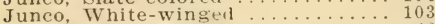

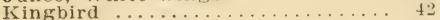

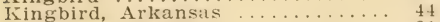

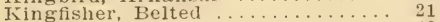

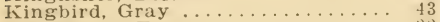

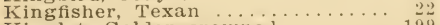

Kinglet, Golden-crowned .......... 199

Kinglet, Ruby-crowned .......... 200

Lark, Horned ................ 53

Lark, Horned Desert .............. 53
Lark, Horned Hoyt .......... 53

Lark, Horned Prairie ............ 53

Leucosticte, Gray-crowned ....... 78

Longspur, Chestnut-collired ..... 86

Longspur, Lapland ............ 84

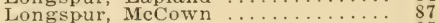

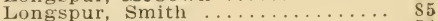

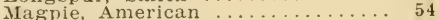

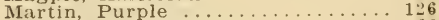

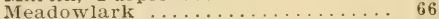

Meadowlark, Florida .......... 66

Meadowlark, Western .......... 66

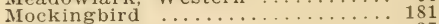

Nighthawk $\ldots \ldots \ldots \ldots \ldots \ldots \ldots \ldots \ldots \ldots . \ldots \ldots$

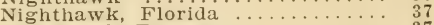

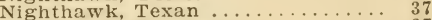

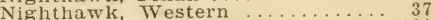

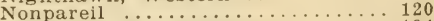

Nuthateh, Brown-headei ........ 194

Nuthatch, Red-breasted .......... 193

Nuthateh, White-breasted ........ 192

Nuthateh, Florida White ......... 192

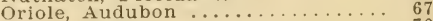

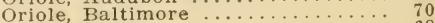

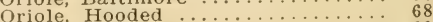

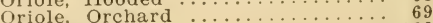

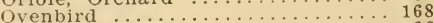

Paraque, iierriil ................. 36 
Pyrrhuloxia

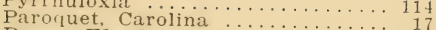

Pewee, Tood .....................

Phoebe ......................... 47

Pipit, American .............. 179

Pipit, Sprague ....................

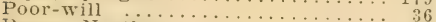

Riaven, Northern ... . . . . . . . . 5

Raven, White-necked ............ 59

Redpoll ....................

Redpoll, Greater ............... 79

Redpoll, Greenland $\ldots \ldots \ldots \ldots \ldots \ldots \ldots$. 79

liedpoll, Hoary ..................

Redpoll, Holboeli .............

Redstart, American ............... 179

Road-runner ................... is

Robin ..................... 206

Robin, Southern .............. 206

Sapsucker, Yellow-bellied .........

Seedeater, Sharp .................. 121

Shrike, Loggerhead ............... 134

Shrike, Northern ... . . . . . . . . . 133

Shrike, White-rumped ........... 1:4

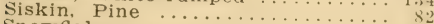

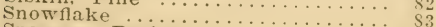

Sparrow, Bachman .............. 106

Sparrow, Baird ..................

Sparrow, Black-throateri ......... 105
Sparrow, Chipping .......... 100

Sparrow, Clay-colored ............. 101

Sparrow, English .............. 88

Sparrow, Field .................... 102

Sparrow, Field Western ............. 102

Sparrow, Fox .................... 110

Sparrow, Grasshopper ............. 110

Sparrow, Harris ................ 96

Sparrow, Henslow .................. 9

Sparrow, Henslow Westeri ....... 92

Sparrow, Ipswich ............. 90

Sparrow, Lark .................. 95

Sparrow, Lark Western .......... 95

Sparrow, Leconte ................ 9

Sparrow, Lincoln ................ 108

Sparrow, Pine-woods .............. 106

Sparrow, Savanna ................ 90

Sparrow, Seaside ................. 94

Sparrow, Seaside Dusky .......... 94

Sparrow, Sharp-tailed ............

Sparrow, Sharp-tailed Acadian .... 93

sparrow, Sharp-tailed Nelson .... 9

Sparrow, Song .................. 107

Sparrow, Seng Dakota............... 107

Sparrow, Swamp ................. 109

Sparrow, Tree ..................

Sparrow, Tree Western ........... 99

sparrow Vesner 
Sparrow, White-crowned ....... 97

Sparrow. White-throated .........

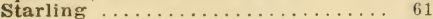

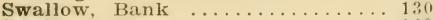

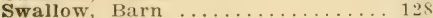

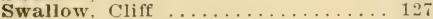

Swallow, Rough-winged ........ 120

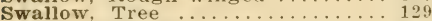

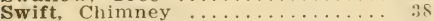

Swift, White-throated ........... 39

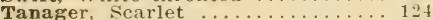

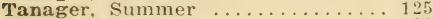

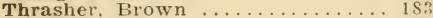

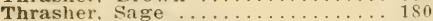

Thrush, Bicknell ........... 205

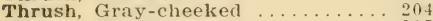

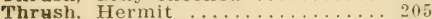

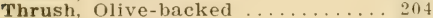

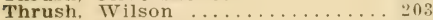

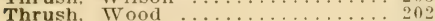

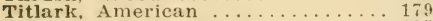

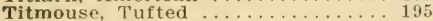

Titmouse, Black-crested .......... 195

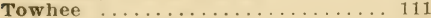

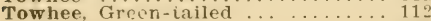

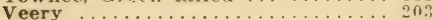

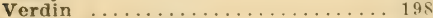

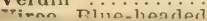

Vireu, Black-capped ........... 13?

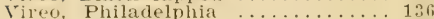

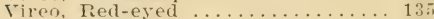

Vireo, Solitary .................... 1:

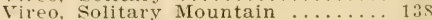

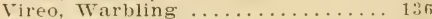

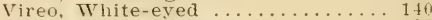

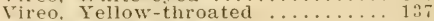

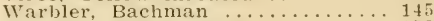

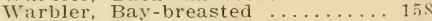

Tiarbler, Black and White......... $1+1$

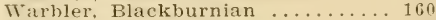

IVarbler, Black-poll ............. 15!

Tiarliler, Black-throated Blue .... 15 .

IVarbler, Black-throated Green.... 16:

WVarbler, Blue-winged ........... 1 if

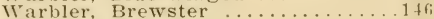

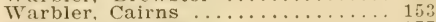

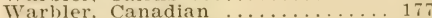

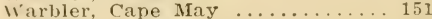

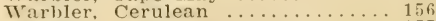

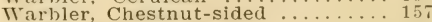

Warbler, Connecticut ..................

Tirbler, Golden-cheeked ........ 162

Trarhler, Golden-winged ................ 117

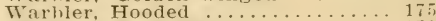

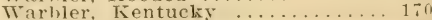

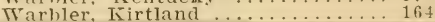




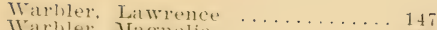

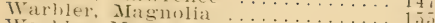

Warbler. Mumrning ...............

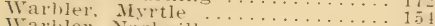

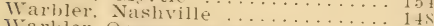

IVarliler, Orange-crowned ............. 1 ts

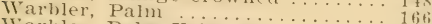

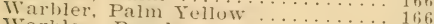

TVarbler, Parula ........................ 150

Trarbler. Parula Northern ......... 150

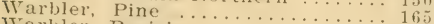

TTarbler. Prairie .............................

Tharbler, Prothonotary ........................

Warbler, sennett ..................... 150

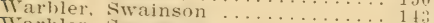

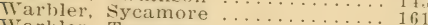

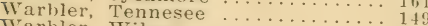

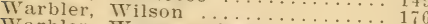

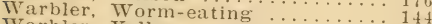

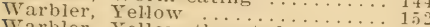

Warbler, Yellow-throated ............. 161

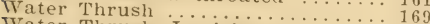

Water Thrush, Louisiana ............... 169

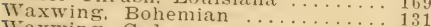

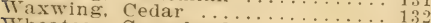

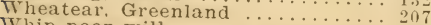

Thip-poor-will .................. 2037

Toodpecker, American Three-toer.
Wroolpecker, Arctic Three-toed... 27

II oolpecker, Downy ............. 25

IV oolpecker, Iowny Northern..... 25

II volpecker, Howny Southern .... 25

IV oodpecker, Golden-winged ...... 32

TVoodpecker, Hairy ............. 24

IV uodpecker, Hairy Northern ....... 24

Woodpecker. Hairy Southern ..... 24

Whoodpecker, Ifory-billed ........ 23

Whoodpecker, Pileated ................... 29

TIoodpecker, Pileated Northern.... 29

Thoodpecker. Ted-liellied ........... 31

Troodpecker, Iied-cockaded ......... 26

Troodpecktal, Red-headed .......... 30

Tloodpecker. Texan ................. 26

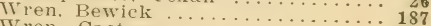

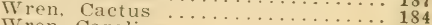

Wren, Carolina ......................... 186

ITren. House .......................... 186

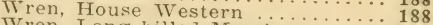

Wren, Long-billed Marsi ............. 198

Wren, Rock ..................... 185

TIren, short-bilied Marsh ......... 190

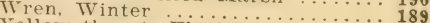

Yellow-throat, Fiorida ................ 173

Yellow-throat, Maryland .............. 173

Yellowthroat, Northern .................173

Yellowthroat Jesteln 



\section{W A T E R B I R D S}

BY CHESTER A. REED, B. S.

This book is uniform in size and scope with LAND BIRDS. It includes all of the Water Birds, Game Birds and Birds of Prey, east of the Rockies. Each sleecies is ILLUSTRATED IN COLOR from oil paintings; the bird, its habits and nesting habits are described.

The pictures show more than 230 birds in color, every species found in our range. They exceed in number those in any other bird book. In quality they cannot be surpassed-exquisite gems, each with an attractive background typical of the habitat of the species.

"LAND BIRDS" and "WATER BIRDS" are the only books, regardless of price, that describe and show in color every bird. 250 pages, neatly boxed.

Bound in Cloth, $\$ 1.00$ net; in Leather, $\$ 1.25$ net; postage, $5 \mathrm{c}$.

CHAS. K. REED, Worcester, Mass. 


\section{F L O W E R G I D E}

BY CHESTER A. REED, B. S.

A guide to the common wild flowers found in the Eastern and Middle States

Wild Flower Guide is the same size and scope as Bird Guide. It has had an extraordinary sale and has been adopted and used in quantities in many of our leading colleges and schools.

The COLORED ILLUSTRATIONS, 192 in number, are beautiful, artistic and accurate reproductions from oil paintings; the finest series ever made. The text tells where each is found, when it blooms, whether in woods, fields, swamps, etc., the height that the plant attains, whether it is self-fertilized or cross fertilized by insects and how; in fact it gives a great deal more information than one would think possible in a book to fit comfortably in the pocket.

Bound in Cloth, 75c.; in Leather, $\$ 1.00$; postage, $5 \mathrm{c}$.

CHAS. K. REED, Worcester, Mass. 


\title{
NORTH AMERICAN BIRDS' EGGS
}

\author{
By CHESTER A. REED, B. S.
}

This is the only book on the market that gives illustrations of the eggs of all North American birds. Fach egg is shown FULL SIZE, photographed directly from an authentic and well marked specimen. There are a great many full-page plates of nests and eggs in their natural situations.

The habitat and habits of each bird are given.

It is finely printed on the best of paper and handsomely bound in cloth. 350 pages $-6 \times 9$ inches.

$\$ 2.50$ net; postage $25 \mathrm{c}$.

\section{COLOR KEY TO N. A. BIRDS}

\section{By F. M. CHAPMAN and C. A. REED}

This might well be called an illustrated dictionary of North American birds, the male of each species being shown in COLOR from pen and ink drawings. Uniform with Egg Book. 350 pages.

$\$ 2.50$ net; postage $25 \mathrm{c}$.

CHAS. K. REED, Worcester, Mass. 


\title{
Wild Flowers East of the Rockies
}

\author{
BY CHESTER A. REED, B. S. \\ LARGER AND EVEN MORE COMPLETE \\ THAN FLOWER GUIDE.
}

SIZE- $4 \times 6$ in.; 450 pages. TEXT-Complete, interesting and instructive. ILLUSTRATIONS-320 Flowers beautifully illustrated IN NATURAL COL(2) RS; painted from life by the author.

Finely printed and handsomely bound in cloth.

$$
\$ 2.50 \text { net; postage } 15 \mathrm{c} \text {. }
$$

CHAS. K. REED - - Worcester, Mass. 


\title{
Nature Studies---Birds
}

\author{
By CHESTER A. REED, B. S.
}

A Book for Boys and Girls and for Beginners in Bird Study.

The first chapters deal with bird lore in general: Migration, Moulting, Flight, Nest-building, etc.

The second part, and major portion of the book contains interesting bird stories as related to Dorothy and Dick, by their Uncle George. These stories are true sketches of bird life and give one accurate knowledge of the habits of birds representing nearly all the families.

SIZE- $5 \frac{1}{2} \times 7 \frac{1}{2}$ in.; 112 pages.

ILLUSTRATIONS-Forty in Color.

PRICE and BINDING-Neatly bound in gray cloth.

$60 \mathrm{c}$ net; postage $10 \mathrm{c}$. 


\section{Nature Studies---In Field and Wood}

By CHESTER A. REED, B. S.

A study of the Animate and Inanimate Things to be found in the Country.

A very interesting and popular account of the many common and curious creatures and flowers that one finds during a ramble in feeld or wood.

This book is very valuable for developing the powers of observation in boys and girls, by calling their attention to the very interesting phenomena that usually are passed by without notice.

Every page is a page of interest,--a page of facts; facts that you may not have noticed or had called to your attention, but which you can take the greatest of pleasure in verifying during your future rambles.

112 pages, size $; 1 / 2 \times 71 / 2$ in. 40 illustrations in color and black and white.

$60 \mathrm{c}$ net; postage $10 \mathrm{c}$.

CHAS. K. REED - - Worcester, Mass. 


\title{
Camera Studies of Wild Birds In Their Homes
}

\author{
By CHESTER A. REED, B. S.
}

DID YOU?

EVER WATCH BIRDS?

Building their homes?

Sitting upon their eggs?

Feeding their little ones?

Shading them from the hot sun-rays?

Sending them into the wide, wide World?

CAIIERA STUDIES not only tell you about these things but SHOW'S YOU.

It is illustrated by more than 200 photographs of bird life. These are selected as the very best from the author's collection of more than 2000 subjects.

350 lages, $5 \frac{1}{2} \times 7 \frac{1}{2}$ in.; handsomely bound in cloth.

$\$ 2.00$ net; postage $20 \mathrm{c}$.

CHAS. K. REED - - - Worcester Mass 


\section{GUIDE TO THE MUSHROOMS}

\section{MY EMMA TAYLOR COLE}

Tells HOW, IVHEN and WHERE they grow; how to collect and prepare them for the table; describes the common kinds both edible and poisonous. Handsomely illustrated with about 70 halftones from photographs of living mushrooms and five PLATES IN COLOR. Uniform with "Wild Flowers."

$\$ 1.50$ net; postage $10 \mathrm{c}$.

\section{GOLDFISH, AQUARIA and FERNERIES}

How to make aquaria. How to fit them up; all about goldfish and fresh water fish that are suitable for the aquarium. Water plants are described, as well as many curiosities that can be kept in the tank. All these things are FINELY ILLUSTRATED. Cloth bound, 50c.; postage, $5 \mathrm{c}$.

\section{GUIDE TO TAXIDERMY}

A practical and thorough instructor in the art of mounting birds, mammals, head, fish, etc. We have an illustrated prospectus for those interested. Fully illustrated; cloth bound; 310 pages. $\$ 1.65$ postpaid. 


\section{COLORED BIRD PICTURES}

Wre have the 40 birds, listed below, each printed on paper $3 \times 4$ in. USED IN SCHOOLS for compositions and decorations. Artistically grouped and framed, they make beautiful pictures for home or school.

Bluebird, Chicliadee, Nuthatch, Wren, Catbird, Redstart, Black-throated Green Warbler, Shrike, Barn Swallow, Tanager, Towhee, Junco, Chipping Sparrow, Goldfinch, Oriole, Redwing Blackbird, Cowbird, Pewee, Kingbird, Jay, HummingSparrow Hawk, Dove, Grouse, Quail, Sandpisher, Cuckoo, Barred Owl, Osprey, Pelican, Cormorant, Tern, Gull, Loon.

FORTY BIRDS-ONE CENT EACH. In lots of ten or more; assorted or alike. FORTY BIRDS-ONE CENT EACH.

In lots of ten or more; assorted or alilie. 


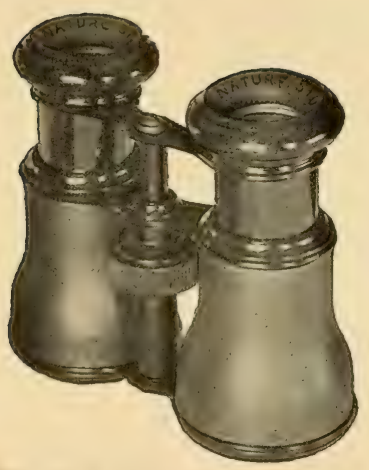

\section{FIELD GLASSES FOR BIRD}

\section{STUDY}

or equally good for the mountain, sea shore or theatre, or wherever a large, clear image of an object is desired.

IVe carefully examined more than a hundred makes of field glasses, to select the ones best adapted for bird study.

We found one make that was superior to any other of the same price and equal optically, and nearly as well made as those costing three times as much.

They magnify about three diameters, and have an unusually large field of vision or angle of riew, making it easy to find a bird or lieep him in sight. Price $\$ 5.00$ postpaid. 



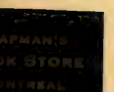



SMITHSONIAN INSTITUTION LIBRARIES 